\title{
The (Minimal) Persuasive Advantage of Political Video over Text
}

\author{
Chloe Wittenberg ${ }^{1 *}$, Ben M. Tappin ${ }^{1,2}$, Adam J. Berinsky ${ }^{1}$, and David G. Rand ${ }^{2,3}$ \\ ${ }^{1}$ Department of Political Science, Massachusetts Institute of Technology, Cambridge, MA 02139; ${ }^{2}$ Sloan School of \\ Management, Massachusetts Institute of Technology, Cambridge, MA 02139; ${ }^{3}$ Department of Brain and Cognitive \\ Sciences, Massachusetts Institute of Technology, Cambridge, MA 02139 \\ * Corresponding author: cwitten@mit.edu
}

Concerns about video-based political persuasion are prevalent in both popular and academic circles, predicated on the assumption that video is more compelling than text. To date, however, this assumption remains largely untested in the political domain. Here we provide such a test. We begin by drawing a theoretical distinction between two dimensions for which video might be more efficacious than text: (i) one's belief that a depicted event actually occurred, and (ii) the extent to which one's attitudes and behavior are changed. We test this model across two highpowered survey experiments varying exposure to politically persuasive messaging (total $n=$ 7609 Americans; 26,584 observations). Respondents were shown a selection of persuasive messages, drawn from a diverse sample of 72 clips. For each message, they were randomly assigned to one of three conditions: a short video, a detailed transcript of the video, or a control condition. Overall, we find that individuals are more likely to believe an event occurred when it is presented in video versus textual form, but the impact on attitudes and behavioral intentions is much smaller. Importantly, for both dimensions, these effects are highly stable across messages and respondent subgroups. Moreover, when it comes to attitudes and engagement, the difference between the video and text conditions is comparable to, if not smaller than, the difference between the text and control conditions. Taken together, these results call into question widelyheld assumptions about the unique persuasive power of political video over text.

Keywords: political persuasion; communication modality; video; text; generalizability

Forthcoming in Proceedings of the National Academy of Sciences

Posted October 18, 2021 


\section{Significance}

Video is an increasingly common source of political information. Although conventional wisdom suggests that video is much more persuasive than other communication modalities, such as text, this assumption has seldom been tested in the political domain. Across two large-scale randomized experiments, we find clear evidence that "seeing is believing": individuals are more likely to believe an event took place when shown information in video versus textual form. When it comes to persuasion, however, the advantage of video over text is markedly less pronounced, with only small effects on attitudes and behavioral intentions. Together, these results challenge popular narratives about the unparalleled persuasiveness of political video versus text.

\section{Introduction}

With the rise of social media, video is more important than ever as a means of political persuasion (Pew Research Center, 2014). Although video has long been a popular tool for political communication (Fowler et al., 2016), video-sharing websites, such as YouTube, have created new opportunities for individuals to seek out and encounter political content online (Harwell, 2016; Shearer \& Gottfried, 2017; Stocking et al., 2020). This growing prominence of video as a political medium raises concerns that for many people "seeing is believing" — and therefore that video may be especially persuasive relative to the more traditional modality of text. These fears are particularly acute given the newfound ability of artificial intelligence to generate ultra-realistic "deepfake" videos of events that never occurred (CNN Business, 2019; Rothman, 2018).

Nevertheless, despite the widely held intuition that video is more believable and compelling than text, surprisingly little research to date has examined whether this assumption applies in political contexts. Outside the domain of politics, a long line of research has yielded inconclusive findings regarding the impact of video versus text on recall of factual information (e.g., Corston \& Colman, 1997; Furnham \& Gunter, 1987; Jones et al., 2005; Yadav et al., 2011), engagement with and attention to message content (Fishfader et al., 1996; Mohammadi et al., 2013; Pezdek et al., 2010), and opinion change (Chaiken \& Eagly, 1976, 1983). Within the political realm, the relative persuasive advantage of video versus text likewise remains an open 
question (Andreoli \& Worchel, 1978; Pfau et al., 2000; Worchel et al., 1975). Although some scholars argue that video's audiovisual components can improve recall of political information (Graber, 1990; Prior, 2014) and facilitate persuasion (Glasford, 2013; Goldberg et al., 2019; Grabe \& Bucy, 2009; Sundar et al., 2021), others suggest that textual information may more effectively mobilize political action (Powell et al., 2018).

Furthermore, whereas past research suggests that persuasive writing (e.g., print news, opeds) can cause sizable and lasting changes in policy attitudes (Chong \& Druckman, 2010; Coppock et al., 2018; Kuziemko et al., 2015), video-based persuasion - particularly in the form of political advertising - seems to have, at most, small and short-lived effects on candidate evaluations and voting intentions (Coppock et al., 2020; Gerber et al., 2011; Hill et al., 2013; although see Huber \& Arceneaux, 2007). Taken at face value, these results might imply a persuasive advantage of text over video. However, it is difficult to draw comparisons between these two strands of research, which tend to employ different methodologies and study different outcome variables. For instance, prior studies that examine the effects of political advertising on voting behavior may detect less persuasion than text-based studies focused on policy attitudes simply because individuals have stronger prior beliefs about candidates versus issues (Broockman \& Kalla, 2020; DellaVigna \& Gentzkow, 2010). As such, it remains unclear whether political video can meaningfully persuade the public and, if so, whether its effects exceed those of equivalent text modalities.

Here, we directly test whether political video is more compelling than text. We begin with the observation that an enhanced impact of video (relative to text) could occur across either or both of two distinct dimensions. First, there is the belief that the information being conveyed is genuine - for example, that a depicted event actually occurred, or that a speaker actually made a particular claim. Second, there is the extent to which this information is persuasive that is, the extent to which the information alters individuals' attitudes or behavior. These two dimensions are theoretically dissociable, in that individuals might believe a claim was made but not find that claim persuasive, or they might not believe a claim was made but nonetheless update their attitudes (e.g., because the presented information resonates with their prior beliefs).

We hypothesize that communication modality strongly influences the first dimension but may have a lesser impact on the second. Previous work suggests that the ease with which information is processed (its "fluency") shapes its perceived truthfulness (Alter \& Oppenheimer, 
2009; Reber \& Schwarz, 1999). To the extent that videos are easier to process than text, they may therefore feel intuitively more believable (for a discussion, see Vaccari \& Chadwick, 2020). As a result, it is perhaps unsurprising that multimodal misinformation is often viewed as highly credible (Dobber et al., 2020; Ternovski et al., 2021; Vaccari \& Chadwick, 2020) - especially relative to textual misinformation (Hameleers et al., 2020; Sundar et al., 2021; though see Barari et al., 2021). However, even if individuals more readily believe that an event occurred if it is shown on video versus relayed in text, this increased credibility may or may not have downstream consequences for attitudes and behavior, particularly when it comes to highly polarized issues. By decomposing the impact of video versus text into these two elements, we can more precisely identify the mechanisms that underlie previously documented communication modality effects.

To test this conceptual model, we conducted two high-powered survey experiments with diverse U.S. samples. The first of these studies was fielded on Lucid between March and April of 2021 (Study 1; $n=4266 ; 16,735$ total observations), and the second was fielded on Dynata in May of 2021 (Study 2; $n=3343 ; 9849$ total observations). In both studies, respondents were presented with a random selection of persuasive messages. For each message, respondents were randomly assigned to watch a short video clip, read an annotated transcript of the video clip, or receive no new information (the control condition). We employed a within-subject design, such that respondents could be assigned to different experimental conditions for each of the messages they were shown. We sought to include a wide variety of policy-relevant clips in order to understand the general effect of video versus text across subject areas (Reeves et al., 2016; Wells $\&$ Windschitl, 1999); to this end, across our two studies we incorporated a total of 72 persuasive messages, spanning a range of topics and varying in the extent to which their content was political or non-political. For Study 1, we examined 48 messages, all drawn from the Peoria Project's database of professionally-produced political ads. These videos were uniformly political but encompassed a diverse array of hot-button issues (e.g., climate change, healthcare, the minimum wage). In contrast, for Study 2, we focused on a single issue: the COVID-19 pandemic. We compiled a set of 24 clips, each of which was widely viewed on YouTube during the peak of the pandemic in the United States (following guidance from Li et al., 2020). Although some of these clips were again political in nature (e.g., an MSNBC clip of former president Donald Trump discussing testing rates), many were not (e.g., a demonstration of the 
benefits of handwashing in preventing the spread of the virus). Additional details about the stimulus set are available in SI Appendix, Section 1.2.

We examined responses to these messages across four categories of outcomes. In line with our proposed two-dimensional model, we first evaluated the believability of each message by asking respondents in the two treatment conditions to rate the extent to which they thought the events shown in the video or described in the transcript actually took place. For example, for a clip that contained footage of Senator Bernie Sanders advocating for free public college, we asked respondents to rate the extent to which they believed Sanders "actually said that tuition to public colleges and universities should be free." We then measured the persuasiveness of each message by having all respondents — in both the treatment and control groups — report their level of agreement with the message's core persuasive claim (e.g., their agreement that tuition to public colleges and universities should be free). As a secondary measure of persuasion, we then asked respondents in the two treatment groups to indicate their likelihood of sharing the message with a friend or colleague. Finally, for all respondents, we assessed personal engagement using two measures: respondents' interest in learning more about the message's topic, and their perceptions of the relative importance of the message's topic, compared to other issues (Study 1 only).

\section{Results}

To test our main hypotheses, we fit a series of Bayesian multilevel linear regression models, given the clustered structure of the underlying data (Brauer \& Curtin, 2018; McElreath, 2020; Yarkoni, 2020). For each outcome variable, our primary quantity of interest is the average treatment effect (ATE) of exposure to video versus text. The dependent variables in all cases are standardized (see SI Appendix, Section 4.2 for results using the untransformed dependent variables); the reported treatment effects are thus expressed in units of standard deviation (SD). Following our preregistration, we allow the ATE (among other parameters) to vary across both messages and respondents, and we specify vague, weakly informative prior distributions for all model parameters. For each of our analyses, we report the posterior median and the 95\% highest posterior density interval (HPDI). The HPDI is the narrowest region that covers the value of the 
ATE with a 95\% probability, given the data and model. Full model specifications and diagnostics are reported in SI Appendix, Section 2.

Overall, the effects of video versus text are remarkably similar across our two studies

(Fig. 1). In both cases, we observe a positive effect of video versus text on the first dimension of our model: respondents' belief that the presented information is authentic. Specifically, we find that respondents in the video condition are, on average, more likely to believe the events depicted in a message actually occurred, relative to respondents in the text condition (Study 1: 0.26 SD, 95\% HPDI = [0.23, 0.30]; Study 2: 0.28 SD, 95\% HPDI = [0.23, 0.33]). Therefore, as expected, video seems modestly but meaningfully more believable than text. However, the effects are much smaller for the second dimension of our model: the extent to which the presented information is persuasive. In particular, we find a precisely estimated but small effect of video versus text on respondents' attitudes (Study 1: $0.08 \mathrm{SD}, 95 \% \mathrm{HPDI}=[0.05,0.11]$; Study 2: 0.11 SD, 95\% HPDI $=[0.07,0.16])$ and intended sharing behavior (Study 1: $0.08 \mathrm{SD}$, 95\% HPDI $=[0.05,0.10]$; Study 2: $0.08 \mathrm{SD}, 95 \%$ HPDI $=[0.03,0.12])$. Critically, the estimated credible intervals for these two outcome variables rule out ATEs larger than 0.16 standard deviations with greater than $95 \%$ probability, whereas the credible intervals for the belief variable suggest ATEs of at least 0.23 standard deviations. Thus, the effect of video versus text appears substantially larger for belief than for persuasion. Moreover, we find minimal evidence that video is more engaging than text, either in terms of respondents' interest in learning more about the message $($ Study 1: $0.01 \mathrm{SD}, 95 \% \mathrm{HPDI}=[-0.01,0.04]$; Study 2: $0.01 \mathrm{SD}, 95 \% \mathrm{HPDI}=$ $[-0.03,0.05])$ or the perceived importance of the message's topic (Study 1: 0.04 SD, 95\% HPDI $=[0.01,0.07])$. In sum, although video may be more believable than text, this enhanced credibility does not seem to be accompanied by a commensurate increase in persuasion or personal engagement. 


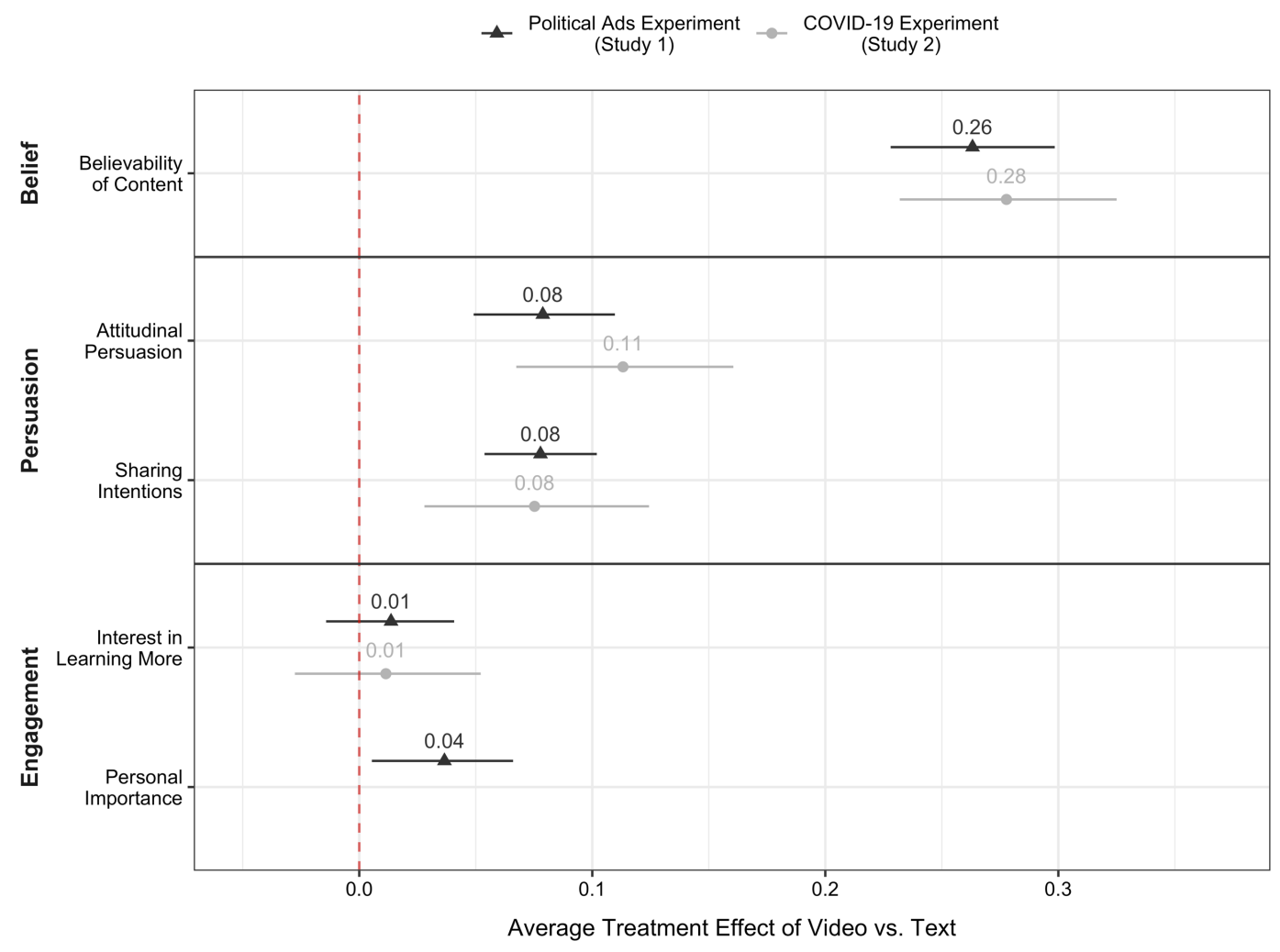

Figure 1. Average treatment effect (ATE) of assignment to the video versus text condition on ratings of believability, persuasion, and personal engagement. All estimates are expressed in units of standard deviation. The point estimate of the ATE is based on the posterior median; specifically, we compute the median of the posterior distribution on the fixed effect parameter for the dummy variable indicating assignment to the video versus text condition. 95\% HPDIs are displayed. Note that ratings of personal importance are only available for Study 1.

These aggregate patterns are likewise apparent for individual stimuli. When examining the ATEs of video versus text for each of our 72 persuasive messages, we find that the strongest ATE on attitudes remains smaller than the weakest ATE on beliefs (Fig. 2). In other words, we find that, across the board, the relative believability of video versus text is greater than the relative persuasiveness of these two modalities. Furthermore, for Study 2, we find few differences in treatment effects when comparing political and non-political messages about COVID-19, suggesting that these limited persuasion effects are not just contained to overtly political content (rightmost column of Fig. 3). Finally, the treatment effects appear quite stable across respondent subgroups (Fig. 3); we do not observe consistent differences in the persuasiveness of video versus text based on demographic traits (e.g., age), political attributes (e.g., partisanship, political knowledge), or personal dispositions (e.g., cognitive reflection). 
Altogether, our results therefore appear to be highly generalizable across different types of messages and across different sub-populations.

Importantly, however, the relatively small differences between video and text should not be taken as evidence that neither form of appeal is persuasive. On the contrary, both video and text seem to affect political attitudes and engagement. Using the control group as a benchmark, we find that exposure to text corresponds to a small but detectable change in respondents' attitudes (Study 1: 0.07 SD, 95\% HPDI $=[0.04,0.11]$; Study 2: 0.14 SD, 95\% HPDI $=[0.08$, 0.20]; see SI Appendix, Section 4.1). This difference in persuasion between the text and control conditions is similar to - if not larger than - the difference between video and text, suggesting that both forms of persuasive messaging have the potential to shape public opinion. Moreover, these two modalities do not meaningfully differ from one another in their effect on personal engagement, despite both increasing engagement relative to a true control where no information was displayed. In Study 1, for example, video and text have similar effects on respondents' interest in learning more about the message's topic (video vs. control: $0.05 \mathrm{SD}$, 95\% HPDI: [0.01, 0.09]; text vs. control: 0.04 SD, 95\% HPDI: [0.02, 0.08]) and perceptions of the importance of the message's topic (video vs. control: 0.15 SD, 95\% HPDI: [0.11, 0.19]; text vs. control: 0.11 SD, 95\% HPDI: [0.08, 0.15]), compared to the control group. Altogether, these results suggest that video has only a small added benefit over text when it comes to political attitudes and personal engagement. 

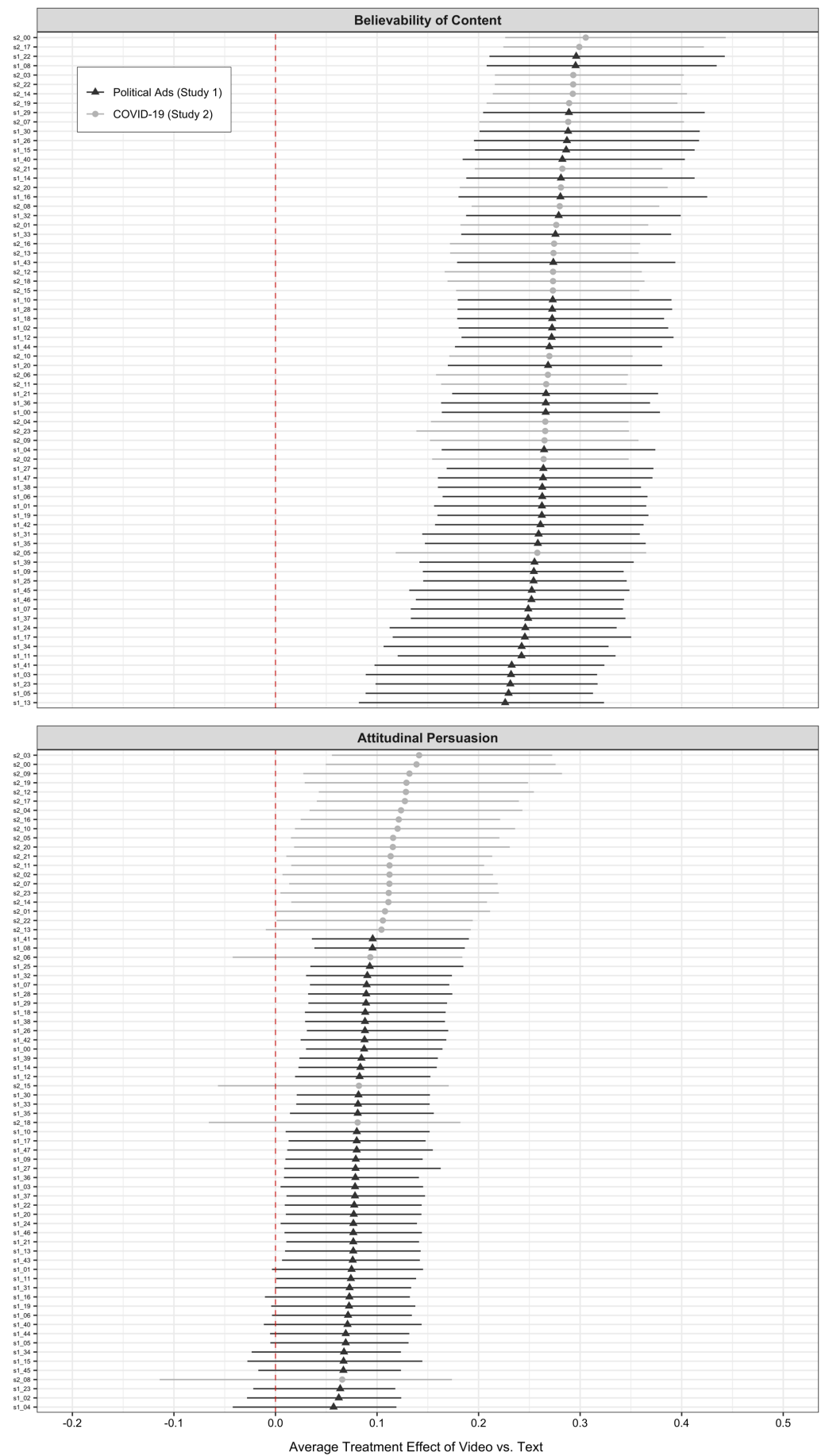

Figure 2. Average treatment effect of assignment to the video versus text condition, disaggregated by persuasive message. All estimates are expressed in units of standard deviation. Posterior medians and 95\% HPDIs are displayed. Note that the message-specific ATEs in these comparisons are mildly regularized, improving their out-ofsample predictive accuracy on average (McElreath, 2020). Additional information about each message is available in SI Appendix, Section 1.2. 


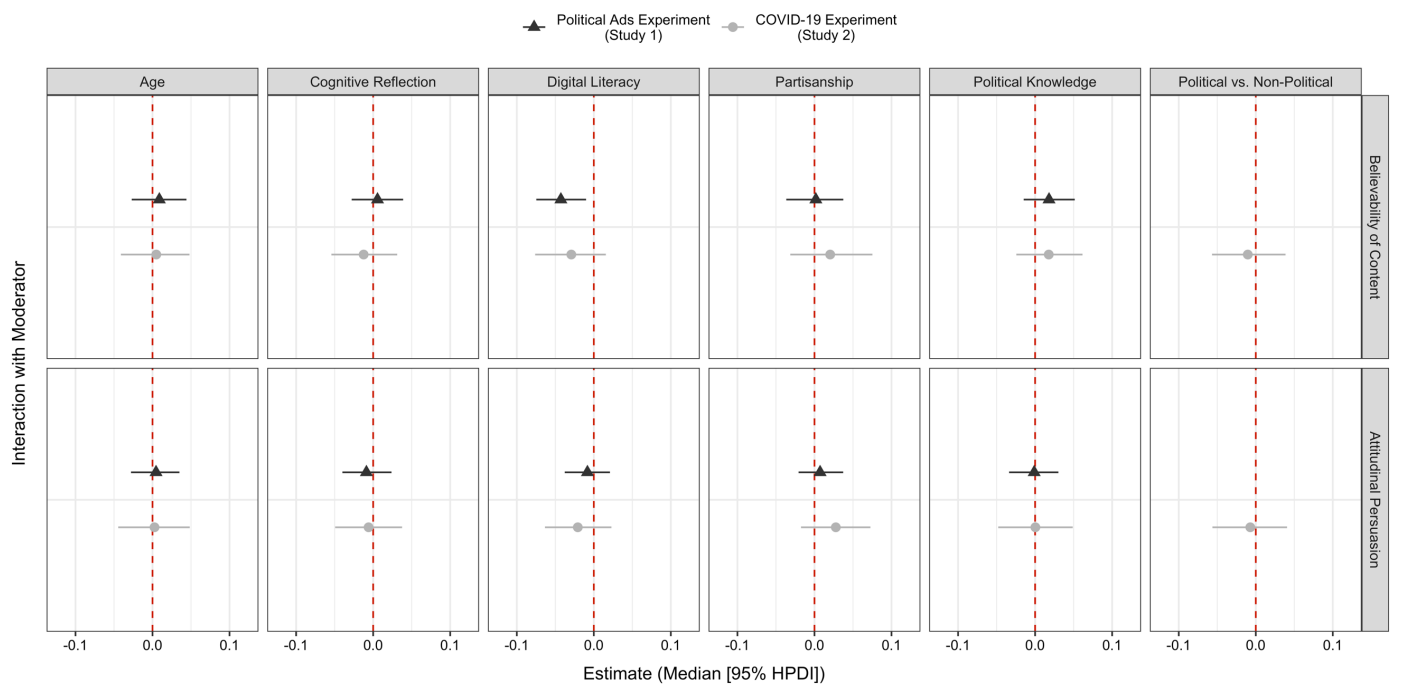

Figure 3. Differences in the average treatment effect of assignment to the video versus text condition based on respondent characteristics (age, cognitive reflection, digital literacy, partisanship, and political knowledge) and message characteristics (political vs. non-political, Study 2 only). The moderator variables in all cases are standardized, and the posterior medians and 95\% HPDIs are displayed. A full summary of the moderator analyses is provided in SI Appendix, Section 4.3.

\section{Discussion}

Across two large-scale studies and nearly 75 video clips, we find that video has a significant, albeit modest, effect on the first dimension of our proposed model: whether presented information is believed to be real. Critically, however, for the second dimension of our model - whether this information is persuasive — video has a much smaller impact on individuals' attitudes and sharing intentions, relative to text. Even if video-based information is more believable than text, this heightened credibility does not seem to guarantee a similar boost in political persuasion. Our findings thus speak to the importance of distinguishing between believability and persuasion when studying media effects. Although conventional wisdom often assumes an intrinsic link between these two constructs, our results suggest that believability and persuasion are far from interchangeable.

Moreover, the relative persuasive advantage of video versus text may in fact be even smaller outside an experimental context. In both of our studies, the text-based treatments were presented in the form of a detailed transcript containing an exact replication of the audio output, as well as a comprehensive description of key visual cues. In reality, politically persuasive writing may be structured quite differently (e.g., as a news article or opinion piece). To the extent 
that these more realistic formats are more compelling than a rote transcription, our studies likely overestimate the differences between video versus text and underestimate the differences between the text and control conditions. However, despite these concerns about external validity, our text-based treatments offer a crucial benefit: they allow us to hold constant the information presented across the two treatment groups. This design enables us to parse the persuasive effect of video that is attributable to the information it contains from the effect that is due to other factors (e.g., affective or visual cues). With this perspective in mind, we find that a substantial portion - as much as half — of video's (relatively small) persuasive effect is tied to noninformational aspects of the medium. However, we cannot discern which features of video have the strongest influence on political persuasion; future work should take up this question.

Given these results, basic assumptions about the primacy of political video over text should perhaps be revisited. One important implication of these findings is that current concerns about the unparalleled persuasiveness of video-based misinformation, including deepfakes, may be somewhat premature. In addition, these findings add nuance to longstanding debates regarding the efficacy of political advertising. Although previous studies find that political ads, particularly in video form, typically have small and fleeting effects on candidate evaluations and voting behavior, our results suggest that both video and text-based ads have the potential to sway the public's policy opinions, even for highly polarized topics like climate change, reproductive rights, or the COVID-19 pandemic. When exposed to persuasive content, members of the public tend to update their issue attitudes in the direction of the message - regardless of whether this content is delivered in video versus textual form.

It should be noted, however, that although we observe only small differences in the persuasiveness of video versus text across our two studies, the effects of these two modalities may diverge more sharply outside an experimental context. In particular, it is possible that video is more attention-grabbing than text, such that people scrolling on social media are more likely to attend to and therefore be exposed to video versus text. As a result, even if video has only a limited persuasive advantage over text within a controlled, forced-choice setting, it could still exert an outsized effect on attitudes and behavior in an environment where it receives disproportionate attention. Efforts to integrate this attentional component of media consumption into future studies may prove informative. Understanding how individuals interact with video versus text content can also help clarify why certain types of content are more or less likely to 
spread via social media. To this end, in both of our studies we measured individuals' stated likelihood of sharing each message with a friend or colleague. However, measures of real-world, rather than self-reported, sharing behavior may be able to better illuminate how video versus text content diffuses online. Field experiments administered directly on social media platforms may be helpful in this regard.

Overall, our results suggest minimal heterogeneity in the persuasiveness of video versus text across messages and respondent subgroups. That these effects are generally stable across messages is especially notable. Although our videos do not constitute a representative sample of all politically persuasive content, we sampled a large and relatively diverse set of clips. Consequently, if there is a powerful effect of video over text — as is often assumed — we would expect to observe it in our experiments. Nonetheless, future research should investigate whether our findings persist across an even more expansive stimulus set. In particular, although we observe clear effects of video on belief in unmanipulated content, future work should explore whether our results replicate in the context of misinformation, including deepfakes as well as socalled "shallow" or "cheapfakes" that use simple editing tricks to craft deceptive footage. In addition, future work should investigate the durability of these effects; although video appears marginally more persuasive than text immediately after exposure, these differences may dissipate over time. Finally, the conceptual model we introduce differentiating belief and persuasion can guide a wide range of future research on media effects both within and outside the political domain.

\section{Materials and Methods}

Data, study materials, and replication code are available online (https://osf.io/xwmqn). All hypotheses and analyses were preregistered (https://osf.io/uy8wc for Study 1; https://osf.io/5se6k for Study 2).

Participants. For the political ads study (Study 1), we contracted with Lucid to recruit a diverse, non-probability sample of the American public (Coppock \& McClellan, 2019), with a preregistered sample size of 4000 respondents. 8381 respondents entered the study, 7982 consented to participate, and 4629 passed a series of technical checks confirming their ability to watch 
video content. Following our preregistration, we retained all respondents who viewed at least one experimental stimulus ( $n=4266 ; \mathrm{M}_{\mathrm{age}}=54 ; 61.3 \%$ female). For the COVID-19 study (Study 2), we preregistered a sample size of 2500 respondents, recruited via Dynata, but ended up including over 700 additional respondents to address concerns about the representativeness of the initial sample. In total, 6082 respondents started the survey, 5713 consented to participate, and 3698 successfully completed the same technical checks as in Study 1. As before, we retained all respondents who viewed at least one experimental stimulus ( $n=3343 ; \mathrm{M}_{\mathrm{age}}=40 ; 54.9 \%$ female). See SI Appendix, Section 1.1 for more information about sample demographics.

For both studies, we sought to recruit an attentive sample of respondents, given recent concerns about rising rates of inattentiveness on online survey panels (Aronow et al., 2020; Peyton et al., 2021). To filter out disengaged respondents, we required all respondents to pass a stringent audiovisual check confirming their ability and willingness to watch video content before proceeding to the rest of the study. Specifically, immediately after providing informed consent, respondents were shown a brief test clip and were then asked two questions to determine whether they both watched and listened to this clip. Respondents who failed to answer these questions correctly after two attempts were removed from our sample. SI Appendix, Section 1.4 describes this procedure in greater detail. In addition, the survey also included two instructional manipulation checks ("screeners," see Berinsky et al., 2014) designed to assess respondent inattentiveness; when we stratify participants based on their responses to these two screener items, we find largely similar treatment effects across groups (see SI Appendix, Section 5.4).

Experimental Procedure. Both studies employed a nearly identical experimental procedure. Respondents first answered a series of pretreatment questions, including a standard demographic battery, a four-item political knowledge scale (Delli Carpini \& Keeter, 1996), a four-item Cognitive Reflection Test (Frederick, 2005; Thomson \& Oppenheimer, 2016), and a six-item digital literacy scale (Guess \& Munger, 2020).

After completing these items, respondents were assigned to view a random selection of messages, presented in random order. For Study 1, respondents were shown four messages (from a list of 48), and for Study 2, respondents were shown three messages (from a list of 24). To 
avoid spillover across similar topics, we grouped these messages into high-level categories, and respondents were allowed to view only a single message from within a given category. For each message, respondents were then randomly assigned to one of three conditions: (i) the video condition, in which they were asked to watch a short video clip, (ii) the text condition, in which they were asked to read a detailed transcription of the video clip, and (iii) the control condition, in which no new information was provided. Further details about the randomization procedure can be found in SI Appendix, Section 1.3. Finally, after viewing each message, respondents completed a series of outcome variables, described in the Measures section below.

For Study 1, all experimental stimuli were drawn from the Peoria Project's database of politically persuasive messages (https://thepeoriaproject.org/videos/). For Study 2, we instead compiled our own set of widely-viewed YouTube clips about the COVID-19 pandemic. See $S I$ Appendix, Section 1.2 for a description of the stimulus selection process.

Measures. We measured each of our dependent variables using five-point scales. Note that our outcome variables were all based on single-item scales. Although multi-item scales have important benefits, we opted to use single-item scales in light of concerns about the overall length of the survey instrument and the associated risks of respondent attrition and response satisficing (Bergkvist \& Rossiter, 2007).

First, we asked respondents in the video and text conditions to rate the believability of the content - that is, their perceptions of whether the depicted events actually occurred — using the following format: "To what extent do you believe [the speaker] actually [made a particular claim from the message]?" ( 1 = Definitely did not happen, $5=$ Definitely happened $)$. Second, we asked respondents in all three conditions to rate their attitudes regarding the subject of the message — that is, whether they agreed or disagreed with the core persuasive claim — using the following format: "Please rate the extent to which you agree or disagree with the following statement: [Persuasive claim from the message]" ( 1 = Strongly disagree, $5=$ Strongly agree $)$. Third, in Study 1, we asked all respondents how important the message's topic was to them personally, using the following format: "How important is [the subject of the persuasive message] to you, relative to other issues?" $(1=$ Not at all important, $5=$ Extremely important $)$. 
Fourth, we asked all respondents to rate their interest in learning more about the message's topic, using the following format: "To what extent are you interested in learning more about [the subject of the persuasive message]?" (1 = Not at all interested, $5=$ Extremely interested). Lastly, we asked respondents in the video and text conditions to rate their likelihood of sharing the content with others: "How likely would you be to share the message you just saw with a friend or colleague?" ( 1 = Not at all likely, 5 = Extremely likely). The exact wording of all outcome measures is available in SI Appendix, Section 1.4.

Analysis Strategy. To test our main hypotheses, we fit a series of Bayesian multilevel linear regression models using the brms package in R (Bürkner, 2017; Stan Development Team, 2020). For models comparing the effects of video versus text, our primary quantity of interest is the parameter on a dummy variable indicating assignment to the video versus text condition, representing the average treatment effect (ATE) of exposure to video versus text. However, for our measures of attitudinal persuasion and personal engagement, we also include a second dummy variable indicating assignment to the control versus text condition. We allow the parameters on these two dummy variables (and the intercept) to vary across both respondents and messages (that is, a "maximal" random effects structure, see Barr et al., 2013).

For our moderator models, we again fit Bayesian multilevel linear regression models but, for each potential moderator, linearly interact the treatment indicators with the (standardized) moderator variable. For models assessing heterogeneity based on respondent characteristics (e.g., age, partisanship), we allow all parameters to vary across messages but allow only the intercept and ATE parameters to vary across respondents, given that the moderator variables are measured at the respondent-level and therefore do not vary for a given respondent across messages. The reverse is true for models assessing heterogeneity based on message-specific attributes (e.g., political vs. non-political videos). Additional details about the model specifications can be found in SI Appendix, Section 2.

We obtain satisfactory convergence for most parameters and models (SI Appendix, Section 2.32.4). However, because we had relatively few observations per respondent, in several cases the sampling chains for the respondent-level random effects were not sufficiently well mixed. As a 
robustness check we refit all of our models without the respondent-level random effects and find nearly identical estimates as those in the full, preregistered models (for a side-by-side comparison, see SI Appendix, Section 5.2). We thus report the estimates from our original specifications here.

Political Classification. For Study 2, we included a mix of both political and non-political messages related to the COVID-19 pandemic. We used crowd-sourced classification $(n=164$ respondents, recruited via Amazon Mechanical Turk) to categorize the content of each video, based on a two-stage process. First, respondents were asked, in their opinion, whether the video was political or non-political. If they selected one of these two options, they were then asked how confident they were in this classification, using a five-point scale. If they selected "Not sure," they were then asked whether, if forced to choose, they thought the video was political, non-political, or if they were still unsure. Responses to these two sets of questions were recoded into a 13-point score, ranging from -6 (Extremely confident non-political) to 6 (Extremely confident political).

Consent and Ethics. All respondents provided informed consent, and both studies were approved as exempt by the MIT Committee on the Use of Humans as Experimental Subjects, protocols no. E-3075 and E-3150. After completing the experimental portion of the survey, respondents were debriefed about the goals of the study and were told that the content they were shown was, to the best of our knowledge, authentic. Additionally, at two points in Study 2, we informed respondents that some of the messages they were shown were produced at the beginning of the pandemic (as early as January 2020) and might contain out-of-date information. First, prior to the experimental portion of the study, we told respondents that some of the content they might see was created earlier in the pandemic and might not reflect current events or public health guidance. Then, at the end of the study, we again reminded respondents about the timing of the clips and provided links to up-to-date information from the Centers for Disease Control and Prevention (CDC). 


\section{Acknowledgments}

We thank Paige Bollen, Naylah Canty, Emily Huang, Paul Irvine, John Jones, Liberty Ladd, Ji Min Lee, Rorisang Lekalake, Anna Weissman, and Nicole Wilson for research assistance; Reagan Martin for video editing assistance; and Rocky Cole, Yasmin Green, Andrew Gully, Zach Markovich, and participants at the MIT Behavioral Research Lab for helpful comments and advice. We are especially grateful to Jonathan Zong for his involvement in the design and development of our pilot study. We gratefully acknowledge funding from Jigsaw. 


\section{References}

Alter, A. L., \& Oppenheimer, D. M. (2009). Uniting the Tribes of Fluency to Form a Metacognitive Nation. Personality and Social Psychology Review, 13(3), 219-235. https://doi.org/10.1177/1088868309341564

Andreoli, V., \& Worchel, S. (1978). Effects of Media, Communicator, and Message Position on Attitude Change. Public Opinion Quarterly, 42(1), 59-70. https://doi.org/10.1086/268429

Aronow, P. M., Kalla, J., Orr, L., \& Ternovski, J. (2020). Evidence of Rising Rates of Inattentiveness on Lucid in 2020. SocArXiv. https://doi.org/10.31235/osf.io/8sbe4

Barari, S., Lucas, C., \& Munger, K. (2021). Political Deepfakes Are As Credible As Other Fake Media And (Sometimes) Real Media. OSF Preprints. https://doi.org/10.31219/osf.io/cdfh3

Barr, D. J., Levy, R., Scheepers, C., \& Tily, H. J. (2013). Random effects structure for confirmatory hypothesis testing: Keep it maximal. Journal of Memory and Language, 68(3), 255-278. https://doi.org/10.1016/j.jml.2012.11.001

Bergkvist, L., \& Rossiter, J. R. (2007). The Predictive Validity of Multiple-Item versus SingleItem Measures of the Same Constructs. Journal of Marketing Research, 44(2), 175-184. https://doi.org/10.1509/jmkr.44.2.175

Berinsky, A. J., Margolis, M. F., \& Sances, M. W. (2014). Separating the Shirkers from the Workers? Making Sure Respondents Pay Attention on Self-Administered Surveys. American Journal of Political Science, 58(3), 739-753. https://doi.org/10.1111/ajps. 12081

Brauer, M., \& Curtin, J. J. (2018). Linear mixed-effects models and the analysis of nonindependent data: A unified framework to analyze categorical and continuous independent variables that vary within-subjects and/or within-items. Psychological Methods, 23(3), 389-411. https://doi.org/10.1037/met0000159

Broockman, D., \& Kalla, J. (2020). When and Why Are Campaigns' Persuasive Effects Small? Evidence from the 2020 US Presidential Election. OSF Preprints. https://doi.org/10.31219/osf.io/m7326

Bürkner, P.-C. (2017). brms: An R Package for Bayesian Multilevel Models Using Stan. Journal of Statistical Software, 80(1), 1-28. https://doi.org/10.18637/jss.v080.i01

Chaiken, S., \& Eagly, A. H. (1976). Communication Modality as a Determinant of Message Persuasiveness and Message Comprehensibility. Journal of Personality and Social Psychology, 34(4), 605-614.

Chaiken, S., \& Eagly, A. H. (1983). Communication modality as a determinant of persuasion: The role of communicator salience. Journal of Personality and Social Psychology, 45(2), 241-256.

Chong, D., \& Druckman, J. N. (2010). Dynamic Public Opinion: Communication Effects over Time. American Political Science Review, 104(4), 663-680. https://doi.org/10.1017/S0003055410000493

CNN Business. (2019, January 28). When seeing is no longer believing: Inside the Pentagon's race against deepfake videos. $\mathrm{CNN}$. https://www.cnn.com/interactive/2019/01/business/pentagons-race-against-deepfakes/

Coppock, A., Ekins, E., \& Kirby, D. (2018). The Long-lasting Effects of Newspaper Op-Eds on Public Opinion. Quarterly Journal of Political Science, 13(1), 59-87. https://doi.org/10.1561/100.00016112 
Coppock, A., Hill, S. J., \& Vavreck, L. (2020). The small effects of political advertising are small regardless of context, message, sender, or receiver: Evidence from 59 real-time randomized experiments. Science Advances, 6(36), eabc4046. https://doi.org/10.1126/sciadv.abc4046

Coppock, A., \& McClellan, O. A. (2019). Validating the demographic, political, psychological, and experimental results obtained from a new source of online survey respondents. Research \& Politics, 6(1), 1-14. https://doi.org/10.1177/2053168018822174

Corston, R., \& Colman, A. M. (1997). Modality of Communication and Recall of Health-related Information. Journal of Health Psychology, 2(2), 185-194. https://doi.org/10.1177/135910539700200215

DellaVigna, S., \& Gentzkow, M. (2010). Persuasion: Empirical Evidence. Annual Review of Economics, 2(1), 643-669. https://doi.org/10.1146/annurev.economics.102308.124309

Delli Carpini, M. X., \& Keeter, S. (1996). What Americans Know about Politics and Why It Matters. Yale University Press.

Dobber, T., Metoui, N., Trilling, D., Helberger, N., \& de Vreese, C. (2020). Do (Microtargeted) Deepfakes Have Real Effects on Political Attitudes? The International Journal of Press/Politics, 26(1), 69-91.

Fishfader, V. L., Howells, G. N., Katz, R. C., \& Teresi, P. S. (1996). Evidential and extralegal factors in juror decisions: Presentation mode, retention, and level of emotionality. Law and Human Behavior, 20(5), 565-572. https://doi.org/10.1007/BF01499042

Fowler, E. F., Franz, M. M., \& Ridout, T. N. (2016). Political Advertising in the United States (1st edition). Routledge.

Frederick, S. (2005). Cognitive Reflection and Decision Making. Journal of Economic Perspectives, 19(4), 25-42. https://doi.org/10.1257/089533005775196732

Furnham, A., \& Gunter, B. (1987). Effects of time of day and medium of presentation on immediate recall of violent and non-violent news. Applied Cognitive Psychology, 1(4), 255-262. https://doi.org/10.1002/acp.2350010404

Gerber, A. S., Gimpel, J. G., Green, D. P., \& Shaw, D. R. (2011). How Large and Long-lasting Are the Persuasive Effects of Televised Campaign Ads? Results from a Randomized Field Experiment. American Political Science Review, 105(1), 135-150. https://doi.org/10.1017/S000305541000047X

Glasford, D. E. (2013). Seeing is believing: Communication modality, anger, and support for action on behalf of out-groups. Journal of Applied Social Psychology, 43(11), 22232230. https://doi.org/10.1111/jasp.12173

Goldberg, M. H., van der Linden, S., Ballew, M. T., Rosenthal, S. A., Gustafson, A., \& Leiserowitz, A. (2019). The Experience of Consensus: Video as an Effective Medium to Communicate Scientific Agreement on Climate Change. Science Communication, 41(5), 659-673. https://doi.org/10.1177/1075547019874361

Grabe, M. E., \& Bucy, E. P. (2009). Image Bite Politics: News and the Visual Framing of Elections (1st edition). Oxford University Press.

Graber, D. A. (1990). Seeing Is Remembering: How Visuals Contribute to Learning from Television News. Journal of Communication, 40(3), 134-156. https://doi.org/10.1111/j.1460-2466.1990.tb02275.x

Guess, A. M., \& Munger, K. (2020). Digital Literacy and Online Political Behavior [Preprint]. Open Science Framework. https://osf.io/3ncmk 
Hameleers, M., Powell, T. E., Meer, T. G. L. A. V. D., \& Bos, L. (2020). A Picture Paints a Thousand Lies? The Effects and Mechanisms of Multimodal Disinformation and Rebuttals Disseminated via Social Media. Political Communication, 37(2), 281-301. https://doi.org/10.1080/10584609.2019.1674979

Harwell, D. (2016, March 25). How YouTube is shaping the 2016 presidential election. Washington Post. https://www.washingtonpost.com/news/theswitch/wp/2016/03/25/inside-youtubes-explosive-transformation-of-american-politics/

Hill, S. J., Lo, J., Vavreck, L., \& Zaller, J. (2013). How Quickly We Forget: The Duration of Persuasion Effects From Mass Communication. Political Communication, 30(4), 521547. https://doi.org/10.1080/10584609.2013.828143

Huber, G. A., \& Arceneaux, K. (2007). Identifying the Persuasive Effects of Presidential Advertising. American Journal of Political Science, 51(4), 957-977. https://doi.org/10.1111/j.1540-5907.2007.00291.x

Jones, M. Y., Pentecost, R., \& Requena, G. (2005). Memory for advertising and information content: Comparing the printed page to the computer screen. Psychology \& Marketing, 22(8), 623-648. https://doi.org/10.1002/mar.20077

Kuziemko, I., Norton, M. I., Saez, E., \& Stantcheva, S. (2015). How Elastic Are Preferences for Redistribution? Evidence from Randomized Survey Experiments. American Economic Review, 105(4), 1478-1508. https://doi.org/10.1257/aer.20130360

Li, H. O.-Y., Bailey, A., Huynh, D., \& Chan, J. (2020). YouTube as a source of information on COVID-19: A pandemic of misinformation? BMJ Global Health, 5(5), e002604. https://doi.org/10.1136/bmjgh-2020-002604

McElreath, R. (2020). Statistical Rethinking: A Bayesian Course with Examples in R and STAN (2nd edition). Chapman and Hall/CRC.

Mohammadi, G., Park, S., Sagae, K., Vinciarelli, A., \& Morency, L.-P. (2013). Who is persuasive?: The role of perceived personality and communication modality in social multimedia. Proceedings of the 15th ACM on International Conference on Multimodal Interaction - ICMI '13, 19-26. https://doi.org/10.1145/2522848.2522857

Pew Research Center. (2014). State of the News Media 2014: News Video on the Web: A Growing, if Uncertain, Part of News. Pew Research Center. https://www.journalism.org/2014/03/26/news-video-on-the-web/

Peyton, K., Huber, G. A., \& Coppock, A. (2021). The Generalizability of Online Experiments Conducted During the COVID-19 Pandemic. Journal of Experimental Political Science, 1-16. https://doi.org/10.1017/XPS.2021.17

Pezdek, K., Avila-Mora, E., \& Sperry, K. (2010). Does Trial presentation medium matter in jury simulation research? Evaluating the effectiveness of eyewitness expert testimony. Applied Cognitive Psychology, 24(5), 673-690. https://doi.org/10.1002/acp.1578

Pfau, M., Holbert, R. L., Zubric, S. J., Pasha, N. H., \& Lin, W.-K. (2000). Role and Influence of Communication Modality in the Process of Resistance to Persuasion. Media Psychology, 2(1), 1-33. https://doi.org/10.1207/S1532785XMEP0201_1

Powell, T. E., Boomgaarden, H. G., De Swert, K., \& de Vreese, C. H. (2018). Video Killed the News Article? Comparing Multimodal Framing Effects in News Videos and Articles. Journal of Broadcasting \& Electronic Media, 62(4), 578-596. https://doi.org/10.1080/08838151.2018.1483935

Prior, M. (2014). Visual Political Knowledge: A Different Road to Competence? The Journal of Politics, 76(1), 41-57. https://doi.org/10.1017/S0022381613001096 
Reber, R., \& Schwarz, N. (1999). Effects of perceptual fluency on judgments of truth. Consciousness and Cognition: An International Journal, 8(3), 338-342. https://doi.org/10.1006/ccog.1999.0386

Reeves, B., Yeykelis, L., \& Cummings, J. J. (2016). The Use of Media in Media Psychology. Media Psychology, 19(1), 49-71. https://doi.org/10.1080/15213269.2015.1030083

Rothman, J. (2018, November 12). In the Age of A.I., Is Seeing Still Believing? The New Yorker. https://www.newyorker.com/magazine/2018/11/12/in-the-age-of-ai-is-seeing-stillbelieving

Shearer, E., \& Gottfried, J. (2017, September 7). News Use Across Social Media Platforms 2017. Pew Research Center's Journalism Project. https://www.journalism.org/2017/09/07/news-use-across-social-media-platforms-2017/

Stan Development Team. (2020). Stan Modeling Language Users Guide and Reference Manual, version 2.27. https://mc-stan.org/

Stocking, G., Kessel, P. van, Barthel, M., Matsa, K. E., \& Khuzam, M. (2020, September 28). Many Americans Get News on YouTube, Where News Organizations and Independent Producers Thrive Side by Side. Pew Research Center's Journalism Project. https://www.journalism.org/2020/09/28/many-americans-get-news-on-youtube-wherenews-organizations-and-independent-producers-thrive-side-by-side/

Sundar, S. S., Molina, M. D., \& Cho, E. (2021). Seeing Is Believing: Is Video Modality More Powerful in Spreading Fake News via Online Messaging Apps? Journal of ComputerMediated Communication, zmab010. https://doi.org/10.1093/jcmc/zmab010

Ternovski, J., Kalla, J., \& Aronow, P. M. (2021). Deepfake Warnings for Political Videos Increase Disbelief but Do Not Improve Discernment: Evidence from Two Experiments. OSF Preprints. https://doi.org/10.31219/osf.io/dta97

Thomson, K. S., \& Oppenheimer, D. M. (2016). Investigating an alternate form of the cognitive reflection test. Judgment and Decision Making, 11(1), 99-113.

Vaccari, C., \& Chadwick, A. (2020). Deepfakes and Disinformation: Exploring the Impact of Synthetic Political Video on Deception, Uncertainty, and Trust in News. Social Media + Society, 6(1), 1-13. https://doi.org/10.1177/2056305120903408

Wells, G. L., \& Windschitl, P. D. (1999). Stimulus Sampling and Social Psychological Experimentation. Personality and Social Psychology Bulletin, 25(9), 1115-1125. https://doi.org/10.1177/01461672992512005

Worchel, S., Andreoli, V., \& Eason, J. (1975). Is the Medium the Message? A Study of the Effects of Media, Communicator, and Message Characteristics on Attitude Change. Journal of Applied Social Psychology, 5(2), 157-172. https://doi.org/10.1111/j.15591816.1975.tb01305.x

Yadav, A., Phillips, M. M., Lundeberg, M. A., Koehler, M. J., Hilden, K., \& Dirkin, K. H. (2011). If a picture is worth a thousand words is video worth a million? Differences in affective and cognitive processing of video and text cases. Journal of Computing in Higher Education, 23(1), 15-37. https://doi.org/10.1007/s12528-011-9042-y

Yarkoni, T. (2020). The generalizability crisis. The Behavioral and Brain Sciences, 1-37. https://doi.org/10.1017/S0140525X20001685 


\section{Supporting Information:}

\section{“The (Minimal) Persuasive Advantage of Political Video over Text"}

\section{Contents}

1 Experimental Design $\quad$ S-1

1.1 Sample Demographics . . . . . . . . . . . . . . . . . . . . . S-1

1.2 Stimulus Selection $\ldots \ldots \ldots \ldots \ldots \ldots \ldots$. . . . . . . . . . . . . . .

1.3 Randomization Procedure . . . . . . . . . . . . . . . . . . S-6

1.4 Survey Questionnaire . . . . . . . . . . . . . . . . . . . . S-8

2 Model Specification and Diagnostics $\quad$ S-21

2.1 Primary Analyses . . . . . . . . . . . . . . . . . . . . S-21

2.2 Moderator Models . . . . . . . . . . . . . . . . . . . . . . . . . . . . . . . .

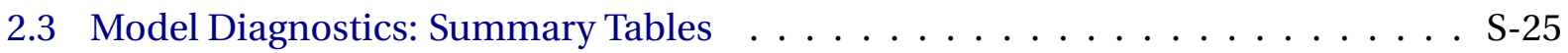

2.4 Model Diagnostics: Trace Plots . . . . . . . . . . . . . . . . . . . . S-30

3 Data Description $\quad$ S-39

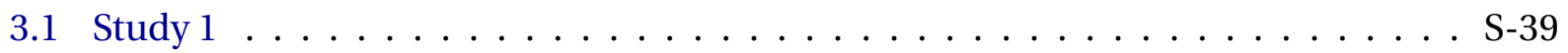

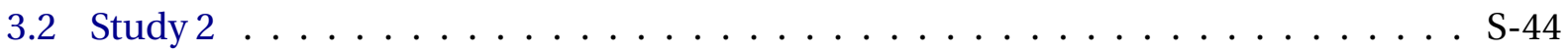

4 Preregistered Analyses $\quad$ S-46

4.1 Comparison to Control Condition . . . . . . . . . . . . . . S S-46

4.2 Results Using Untransformed Dependent Variables . . . . . . . . . . . . . . . . S-47

4.3 Moderator Models . . . . . . . . . . . . . . . . . . S-50

5 Robustness Checks $\quad$ S-52

5.1 OLS Models . . . . . . . . . . . . . . . . . . . . . . . S S-52

5.2 Models without Respondent-Level Random Effects . . . . . . . . . . . . . . . . . . . . . . . . . . . . . . . . .

5.3 Non-Linearities in Moderator Models . . . . . . . . . . . . . . . . . . . . . S-61

5.4 Responses by Attentiveness . . . . . . . . . . . . . . . . . . S S-64

6 Spring 2019 Pilot Study $\quad$ S-66

6.1 Experimental Design . . . . . . . . . . . . . . . . . . . S-66

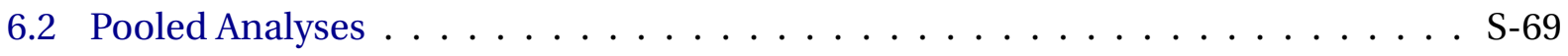

6.3 Message-Specific Analyses . . . . . . . . . . . . . . . . . . . . . S-74 


\section{Experimental Design}

\subsection{Sample Demographics}

\begin{tabular}{|c|c|c|c|}
\hline Variable & Category & Study 1 & Study 2 \\
\hline \multirow[t]{2}{*}{ Gender } & Male & $38.7 \%$ & $45.1 \%$ \\
\hline & Female & $61.3 \%$ & $54.9 \%$ \\
\hline \multirow[t]{6}{*}{ Age } & $18-24$ & $9.6 \%$ & $33.4 \%$ \\
\hline & $25-34$ & $12.8 \%$ & $9.7 \%$ \\
\hline & $35-44$ & $16.8 \%$ & $12.4 \%$ \\
\hline & $45-54$ & $10.9 \%$ & $10.4 \%$ \\
\hline & $55-64$ & $23.5 \%$ & $13.1 \%$ \\
\hline & $65+$ & $26.4 \%$ & $20.9 \%$ \\
\hline \multirow{4}{*}{ Race/Ethnicity } & White & $77.3 \%$ & $59.3 \%$ \\
\hline & Black & $7.5 \%$ & $14.9 \%$ \\
\hline & Hispanic/Latino & $7.4 \%$ & $16.2 \%$ \\
\hline & Other Race/Ethnicity & $7.8 \%$ & $9.5 \%$ \\
\hline \multirow[t]{4}{*}{ Education } & High School or Less & $22.0 \%$ & $42.7 \%$ \\
\hline & Some College & $22.9 \%$ & $16.4 \%$ \\
\hline & College Degree & $40.2 \%$ & $31.1 \%$ \\
\hline & Post-Graduate Degree & $14.9 \%$ & $9.8 \%$ \\
\hline \multirow[t]{3}{*}{ Household Income } & $<\$ 50 \mathrm{~K}$ & $49.0 \%$ & $51.6 \%$ \\
\hline & $\$ 50-100 \mathrm{~K}$ & $31.1 \%$ & $29.2 \%$ \\
\hline & $>\$ 100 \mathrm{~K}$ & $19.9 \%$ & $19.1 \%$ \\
\hline \multirow[t]{3}{*}{ Party ID } & Independent & $15.1 \%$ & $19.9 \%$ \\
\hline & Democrat & $47.1 \%$ & $48.7 \%$ \\
\hline & Republican & $37.8 \%$ & $31.5 \%$ \\
\hline \multirow[t]{3}{*}{ Ideology } & Moderate & $20.7 \%$ & $28.7 \%$ \\
\hline & Liberal & $36.0 \%$ & $34.9 \%$ \\
\hline & Conservative & $43.3 \%$ & $36.4 \%$ \\
\hline
\end{tabular}

Table S1: Sample demographics for Study $1(n=4266)$ and Study $2(n=3343)$. Percents may not add up to 100 due to rounding. Respondents who either did not answer a given question or indicated "Prefer not to say" are excluded from the calculations for that question. For the partisanship and ideology measures, "leaners" are coded as partisans and ideologues, respectively. 


\subsection{Stimulus Selection}

\section{Study 1}

The stimulus set for Study 1 consisted of 48 persuasive messages, all drawn from the Peoria Project's database of politically persuasive messages. We identified relevant clips for the study using the following process:

- We first had two research assistants independently code the content of all videos on the Peoria Project website - including whether each video contained a persuasive claim that could be measured using a close-ended survey question.

- In cases where both RAs agreed that a video did not contain a measurable persuasive claim, we removed that video from the study.

- In cases where the two RAs disagreed about a video's persuasiveness, one of the researchers issued a final judgment.

- Next, we removed duplicate videos from the study. Several of the Peoria Project videos were nearly identical in their content, except that one was edited to be shorter than the other.

- To keep the length of videos as consistent as possible, we retained whichever version of the video was closest to 30 seconds in length.

- Then, two members of the research team independently coded the remaining videos into high-level categories, such that videos pertaining to the same general issue (e.g., climate change, taxes, healthcare) were all grouped into the same category. This step was intended to minimize spillover across videos with similar topics.

- After reconciling the two sets of coding decisions, we ended up with a final list of 15 high-level categories (see Table S2).

- Following this step, we removed two cases where the same speaker appeared across multiple categories, as several videos featured the same narrator discussing different issues or using different message frames.

- In order to ensure that respondents were not shown videos that featured the same speaker, we excluded whichever video fell into the larger high-level category.

- That is, if one video fell into a category with two other videos and the other fell into a category with five other videos, we kept the first clip and removed the second.

- Lastly, we did a final review of the persuasive content of the remaining clips. At this stage, we excluded six additional videos whose persuasive claims were too vague to devise meaningful survey items (e.g., a clip about the importance of diversity) or whose content was out of date at the time of the study (e.g., a clip arguing for the impeachment of former president Donald Trump). 


\section{Study 2}

The stimulus set for Study 2 contained 24 short clips ( $<2$ minutes in length) that had been widely viewed on YouTube during the peak of the pandemic in the United States. We obtained this list of videos through a multi-stage process:

- First, in July of 2020, an RA compiled a list of the top 200 most-viewed clips on YouTube containing the keywords "coronavirus" or "COVID-19," following the procedure described in (1).

- Then, the RA watched each video in full to assess whether it met a series of inclusion criteria.

- Specifically, we excluded any videos that were entirely in a foreign language (without subtitles), did not contain any audio, came from a dynamic livestream, were unrelated to the COVID-19 pandemic, were duplicate posts of other videos on our list, or did not contain footage of a persuasive claim being made.

- Next, we excluded videos that were too long - specifically, videos that did not contain any persuasive claims that were two minutes or less in length (as identified by two RAs).

- Then, two members of the research team independently read the descriptions of the remaining videos to assess whether their content was out of date, given the timing of the study.

- We chose to exclude any clips where at least one coder indicated that the video might be obsolete.

- We then trimmed down the remaining videos to only include the persuasive claim(s) identified by our RAs.

- In cases where more than one persuasive claim was present in a given clip, we opted to focus on only the first of these claims.

- As a final pre-processing step, we removed any videos where we could not reliably measure persuasion using close-ended survey items - for instance, because the persuasive claims referred to predictions about events that had already occurred (e.g., vaccine roll-out, superspreader events) - and any remaining videos whose persuasive claims referenced out-of-date health guidance (e.g., about face masks). 


\section{Final List of Videos}

Tables S2 and S3 outline the videos used in Studies 1-2, respectively. Where possible, we used the same title and description as the original source. However, especially for Study 2, many of the descriptions were unable to be used verbatim because they were either too long or were irrelevant to the excerpted clip. In these cases, we either trimmed down the original description or wrote our own copy (designed to mimic the style of popular YouTube videos). For Study 1, all videos are available on the Peoria Project website, and for Study 2, all videos are available on OSF. Transcripts for both studies are also available on OSF.

\begin{tabular}{|c|c|c|c|}
\hline Video ID & Category & Video Title & Video Description \\
\hline 1000 & Taxes & Abigail Disney & $\begin{array}{l}\text { Heiress Abigail Disney speaks out against the recent tax cuts that disproportionately benefit the } \\
\text { wealthy. }\end{array}$ \\
\hline 1001 & Anti-corporation & Angry Young Man & $\begin{array}{l}\text { Young Trump voter voices frustration at politicians' broken promises and growing corporate power in } \\
\text { our country. }\end{array}$ \\
\hline 1002 & Minimum wage & Autobarn Minimum Wage & $\begin{array}{l}\text { Small business owners with repair garage hire their first employee and believe raising the minimum } \\
\text { wage is the right business decision. }\end{array}$ \\
\hline 1003 & Taxes & Ben Cohen & Ben Cohen illustrates how the wealthy benefit from the recent GOP tax cut legislation. \\
\hline 1004 & Minimum wage & Bob's Crab Shack & $\begin{array}{l}\text { Small business owner in Maine supports paying his workers higher wages because of the benefits to the } \\
\text { economy and their increased productivity. }\end{array}$ \\
\hline 1005 & Climate change & Carbon Pollution & Food is less healthy because of carbon pollution. \\
\hline 1006 & Climate change & Climate Science with Leo & Leo DiCaprio talks about the indisputable science behind climate change. \\
\hline 1007 & Reproductive health & Colorado and Birth Control & Colorado's successful family planning programs also save money. \\
\hline 1008 & Climate change & Cows and Seaweed & Cows contribute to climate change, but adding seaweed to their diets could be beneficial. \\
\hline 1009 & Reproductive health & Defunding Planned Parenthood & Actress Kate Walsh explains the harm in defunding Planned Parenthood. \\
\hline 1010 & Veterans/military & Eddie // Veteran Affairs & Military veteran explains how difficult it is for many veterans to access VA services. \\
\hline 1011 & Education & Education Privatization & Former military officer argues against privatizing education. \\
\hline 1012 & Anti-corporation & $\begin{array}{l}\text { Factory Worker Larry // } \\
\text { Healthcare }\end{array}$ & Retired worker rails against corporate greed as he loses his previously guaranteed healthcare coverage. \\
\hline 1013 & Anti-corporation & $\begin{array}{l}\text { Factory Worker Larry // Jobs } \\
\text { overseas }\end{array}$ & $\begin{array}{c}\text { Retired worker expresses frustration at Trump's broken promises and the growing problem of jobs } \\
\text { moving overseas. }\end{array}$ \\
\hline 1014 & Taxes & Farmer and Tax Cuts & $\begin{array}{c}\text { Farmer in Kansas regrets voting for Brownback after tax cuts decimated the state budget; draws } \\
\text { parallels to Trump tax cuts. }\end{array}$ \\
\hline 1015 & Healthcare & Father Enraged over Trumpcare & An angry father expresses outrage at cuts to Obamacare. \\
\hline 1016 & Taxes & Fox News and Taxes & Footage from Fox Business shows Trump hypocrisy on closing tax loopholes. \\
\hline 1017 & Taxes & $\begin{array}{l}\text { Get the American Dream back on } \\
\text { track }\end{array}$ & Army Veteran suggests that wealthy people should pay more in taxes to fund infrastructure projects. \\
\hline 1018 & Gun ownership & Gun Control & Former Marine argues for sensible gun control regulations. \\
\hline 1019 & Income inequality & Income Inequality // Craig \#1 & Older gentleman calls out growing income inequality problem. \\
\hline 1020 & Minimum wage & KFC Vet and Minimum Wage & Clip of Purple Heart recipient and veteran who works at KFC and argues for $\$ 15$ minimum wage. \\
\hline 1021 & Anti-corporation & $\begin{array}{l}\text { Main Street Economic } \\
\text { Development }\end{array}$ & Main Street development is the wave of the future, not Wall Street. \\
\hline 1022 & Anti-corporation & Main Street Investment & Main Street is the place to invest. \\
\hline 1023 & Drug policy & Marijuana Legalization & Veteran who smokes marijuana for his PTSD argues it should be legal. \\
\hline 1024 & Employee rights & Massachusetts Nurse & Nurse explains harm to children and families when parents don't have access to earned sick leave. \\
\hline 1025 & Internet/tech policy & Net Neutrality & Animated explainer about what's at stake with the repeal of net neutrality rules. \\
\hline 1026 & Healthcare & NJ Nurses & Two nurses show the important caretaking and advocacy role nurses play in our children's lives. \\
\hline 1027 & Healthcare & Nurse and ACA & Republican nurse talks about her support for the ACA and shame in her party's attempts to repeal it. \\
\hline 1028 & Education & Oklahoma Teachers & Teachers protest low pay in Oklahoma where many have second and third jobs to make ends meet. \\
\hline 1029 & Drug policy & Opioid Crisis & A young man in recovery from his opioid addiction argues for more government resources. \\
\hline 1030 & Employee rights & Paid Family Leave (Jamie) & New mom lacked access to paid family leave and was forced to return to work quickly after giving birth. \\
\hline 1031 & Employee rights & Paid Family Leave (Tara) & Woman explains how families, employers, and the economy benefit from paid family leave policies. \\
\hline 1032 & Income inequality & Payday Lending & Woman discusses her experience with a payday lender and extremely high predatory interest rates. \\
\hline 1033 & Healthcare & Protect our People at Home & Army Veteran advocates for affordable health care for all working Americans. \\
\hline 1034 & Employee rights & Real Prosperity & $\begin{array}{l}\text { Woman explains the challenges associated with working after giving birth and advocates for access to } \\
\text { better health care. }\end{array}$ \\
\hline 1035 & Elections & Russian Interference & $\begin{array}{c}\text { American vets talk about disgust with Trump for not standing up for our country against Russian } \\
\text { interference. }\end{array}$ \\
\hline 1036 & Income inequality & Stop with the Games & Man expresses anger at political leaders for playing games and failing to support the American Dream. \\
\hline 1037 & Healthcare & Three Million Dollars & $\begin{array}{c}\text { A mother shares the story of her son's motorcycle accident and advocates for universal health } \\
\text { insurance. }\end{array}$ \\
\hline 1038 & Immigration & Tim Cook and DACA & Tim Cook argues for DACA from a business perspective. \\
\hline 1039 & Income inequality & Time for a Real Change & $\begin{array}{l}\text { Man criticizes politicians who do little to create jobs and provide affordable health insurance for the } \\
\text { middle class. }\end{array}$ \\
\hline 1040 & Education & Tuition Free College & Bernie Sanders advocates for making affordable college a priority in this country. \\
\hline 1041 & Immigration & Undocumented Children & $\begin{array}{l}\text { Children are asked tough immigration questions, highlighting absurdity of undocumented children } \\
\text { often having to represent themselves in immigration court. }\end{array}$ \\
\hline 1042 & Education & Vocational Education & Autotech teacher talks about the value of providing students with a vocational education. \\
\hline 1043 & Anti-corporation & Walmart and Bad Corporations & $\begin{array}{l}\text { Walmart worker talks about how the company doesn't care about her and argues that poor people are } \\
\text { beholden to corporations. }\end{array}$ \\
\hline 1044 & Employee rights & Warren and Child Care & Elizabeth Warren highlights importance of child care with personal anecdote. \\
\hline 1045 & Gun ownership & We Call B.S. & $\begin{array}{l}\text { Student from Parkland High School gives emotional "We Call B.S." rallying cry in response to politicians } \\
\text { who refuse to take action to address gun violence. }\end{array}$ \\
\hline 1046 & Income inequality & We Choose Us // Amber & $\begin{array}{l}\text { Amber advocates for a new generation of leaders to address the problems that many young people are } \\
\text { facing. }\end{array}$ \\
\hline 1047 & Income inequality & We The People // Gaby & $\begin{array}{l}\text { Local organizer Gaby advocates for changing a political system that does not give all families or } \\
\text { communities equal opportunities for success. }\end{array}$ \\
\hline
\end{tabular}

Table S2: Description of videos used in Study 1. 


\begin{tabular}{|c|c|c|c|}
\hline Video ID & Category & Video Title & Video Description \\
\hline 1000 & Preventative health & $\begin{array}{l}\text { How To See Germs Spread } \\
\text { Experiment (Coronavirus) }\end{array}$ & $\begin{array}{l}\text { YouTuber demonstrates how germs can easily spread via physical contact, including handshakes, and } \\
\text { shows how proper handwashing can help to prevent germs from spreading. }\end{array}$ \\
\hline 1001 & Preventative health & How soap kills the coronavirus & $\begin{array}{l}\text { Video shows how plain old soap and water absolutely annihilate the coronavirus - but only after at } \\
\text { least } 20 \text { seconds. }\end{array}$ \\
\hline 1002 & U.S. politics & $\begin{array}{l}\text { Coronavirus IV: Last Week Tonight } \\
\text { with John Oliver }\end{array}$ & $\begin{array}{l}\text { John Oliver discusses how the coronavirus is impacting the U.S. workforce, from mass unemployment } \\
\text { to problems with the Paycheck Protection Program. }\end{array}$ \\
\hline 1003 & Coronavirus vs. flu & $\begin{array}{l}\text { Coronavirus is not the flu. It's } \\
\text { worse. }\end{array}$ & $\begin{array}{l}\text { COVID-19, the disease caused by the coronavirus, has similar symptoms to the flu. They also spread in } \\
\text { similar ways. So it's natural to want to compare the two. But COVID-19 is very different, in ways that } \\
\text { make it much more dangerous. }\end{array}$ \\
\hline 1004 & U.S. politics & $\begin{array}{l}\text { Saluting the Heroes of the } \\
\text { Coronavirus Pandumbic | The } \\
\text { Daily Show }\end{array}$ & $\begin{array}{l}\text { Republican politicians and media figures downplayed the dangers of the coronavirus pandemic in } \\
\text { early } 2020 .\end{array}$ \\
\hline 1005 & U.S. politics & $\begin{array}{l}\text { Tucker: Big Tech censors dissent } \\
\text { over coronavirus lockdowns }\end{array}$ & $\begin{array}{c}\begin{array}{c}\text { Big technology companies are using the COVID-19 tragedy to increase their power over the American } \\
\text { population. }\end{array} \\
\text {. }\end{array}$ \\
\hline 1006 & World politics & $\begin{array}{c}\text { Whistleblowers silenced by China } \\
\text { could have stopped global } \\
\text { coronavirus spread | } 60 \text { Minutes } \\
\text { Australia }\end{array}$ & $\begin{array}{l}\text { Mid-November in Wuhan, China, and cases of a strange new flu start surfacing. The coronavirus } \\
\text { festered at least a month and a half before the world was told, after whistleblowers who warned of the } \\
\text { virus's danger were silenced by China. }\end{array}$ \\
\hline 1007 & U.S. politics & $\begin{array}{l}\text { Why Coronavirus is Hitting the } \\
\text { Black Community Hardest | The } \\
\text { Daily Social Distancing Show }\end{array}$ & $\begin{array}{c}\text { Trevor Noah takes a closer look at why the U.S.'s coronavirus outbreak is disproportionately hurting the } \\
\text { black community. }\end{array}$ \\
\hline 1008 & U.S. politics & $\begin{array}{c}\text { Trump Declares Testing } \\
\text { 'Overrated,' As Coronavirus } \\
\text { Deaths Continue to Rise | MSNBC }\end{array}$ & $\begin{array}{l}\text { As the United States' death toll continued to rise, Donald Trump called coronavirus testing "overrated" } \\
\text { in a speech in May of } 2020 .\end{array}$ \\
\hline 1009 & Preventative health & $\begin{array}{l}\text { WHO: Coronavirus - questions } \\
\text { and answers (Q\&A) }\end{array}$ & $\begin{array}{c}\text { What is a coronavirus? Where do they come from? How can I protect myself? Watch this Q\&A from the } \\
\text { World Health Organization for the answers. }\end{array}$ \\
\hline 1010 & World politics & $\begin{array}{l}\text { Funeral Homes in Mexico Show } \\
\text { Coronavirus' Hidden Death Toll }\end{array}$ & $\begin{array}{l}\text { Mexico is reopening, but those handling the dead say the coronavirus epidemic there is far from over. } \\
\text { Crematoriums and funeral homes are overwhelmed, and mortality data shows the death toll is far } \\
\text { higher than official numbers. }\end{array}$ \\
\hline 1011 & Science/technology & $\begin{array}{l}\text { Is This Coronavirus, or Just } \\
\text { Allergies? Symptoms of COVID-19 }\end{array}$ & $\begin{array}{l}\text { A lot of people might be stressing out these days because they are worried that they have COVID- } 19 . \\
\text { However, COVID-19 tests can give false negatives, making it difficult to know if you do or do not have } \\
\text { the virus. }\end{array}$ \\
\hline 1012 & Preventative health & Coronavirus & Basic information about the novel coronavirus and how to prevent its spread. \\
\hline 1013 & World politics & $\begin{array}{l}\text { How we must respond to the } \\
\text { coronavirus pandemic|Bill Gates }\end{array}$ & $\begin{array}{l}\text { In a conversation with TED founder Chris Anderson, philanthropist and Microsoft cofounder Bill Gates } \\
\text { offers insights into the COVID-19 pandemic, discussing how prepared the world was for another } \\
\text { outbreak. }\end{array}$ \\
\hline 1014 & Science/technology & $\begin{array}{l}\text { Empty middle seats on planes } \\
\text { won't stop the coronavirus }\end{array}$ & $\begin{array}{l}\text { As coronavirus lockdowns loosen, flights are starting to fill up - leading many people to call for empty } \\
\text { middle seats. Keeping middle seats open on a plane can help maintain physical distance between } \\
\text { passengers. But it's unlikely to prevent virus transmission. }\end{array}$ \\
\hline 1015 & Science/technology & $\begin{array}{l}\text { What Are the Craziest } \\
\text { Coronavirus Conspiracy Theories? } \\
\text { | The Daily Social Distancing Show }\end{array}$ & Trevor Noah explores the craziest conspiracy theories about the origin of the coronavirus. \\
\hline 1016 & Coronavirus vs. flu & $\begin{array}{c}\text { Dr. Fauci Answers Trevor's } \\
\text { Questions About Coronavirus | } \\
\text { The Daily Social Distancing Show }\end{array}$ & $\begin{array}{l}\text { Infectious diseases expert Dr. Anthony Fauci shares what makes COVID-19 so insidious, busts myths } \\
\text { about the virus, and breaks down why adhering to public health guidelines is paramount. }\end{array}$ \\
\hline 1017 & Science/technology & $\begin{array}{l}\text { Coronavirus Is Our Future | } \\
\text { Alanna Shaikh |TEDxSMU }\end{array}$ & $\begin{array}{l}\text { Global health expert Alanna Shaikh talks about the coronavirus outbreak and what this can teach us } \\
\text { about the epidemics yet to come. }\end{array}$ \\
\hline 1018 & Preventative health & $\begin{array}{l}\text { How to Significantly Slow } \\
\text { Coronavirus? \#Masks4All }\end{array}$ & $\begin{array}{l}\text { Homemade masks are partly effective in individual protection, but they are essential for slowing the } \\
\text { spread of the virus in the population. }\end{array}$ \\
\hline 1019 & World politics & $\begin{array}{l}\text { China Is Censoring Coronavirus } \\
\text { Stories. These Citizens Are } \\
\text { Fighting Back. | NYT News }\end{array}$ & $\begin{array}{l}\text { Information about the coronavirus outbreak is not immune from Chinese censors. But more and more } \\
\text { citizens are dodging censorship by creating a digital archive of deleted posts. }\end{array}$ \\
\hline 1020 & Preventative health & $\begin{array}{l}\text { What face masks actually do } \\
\text { against coronavirus }\end{array}$ & $\begin{array}{c}\text { The truth is that no mask can actually guarantee that you won't get sick. Masks have to be used } \\
\text { correctly to offer any protection at all, and they're most effective if used alongside other preventative } \\
\text { measures like hand-washing and social distancing. }\end{array}$ \\
\hline 1021 & U.S. politics & $\begin{array}{l}\text { Bill Gates On Coronavirus | } \\
\text { TODAY }\end{array}$ & $\begin{array}{l}\text { Through his foundation, Bill Gates is funding tests and treatments for COVID-19. In April 2020, he } \\
\text { spoke with TODAY's Savannah Guthrie about the importance of continued funding for the World } \\
\text { Health Organization. }\end{array}$ \\
\hline 1022 & Coronavirus vs. flu & $\begin{array}{l}\text { The Real Truth about Coronavirus } \\
\text { by Dr. Steven Gundry }\end{array}$ & $\begin{array}{l}\text { A doctor describes the differences between the flu and COVID-19- and explains why the latter is } \\
\text { especially dangerous. }\end{array}$ \\
\hline 1023 & Preventative health & Get the facts on coronavirus & $\begin{array}{l}\text { Information about the coronavirus outbreak is spreading fast, but what do we actually know about the } \\
\text { illness? CBC News medical contributor and family physician Dr. Peter Lin breaks down the facts about } \\
\text { how it spreads and what you can do to protect yourself. }\end{array}$ \\
\hline
\end{tabular}

Table S3: Description of videos used in Study 2. 


\subsection{Randomization Procedure}

\section{Study 1}

For Study 1, respondents viewed a random selection of four messages, in random order, from a list of 48 possible stimuli (within-subject design). For each video, respondents were randomly assigned to one of three conditions:

1. Video: a brief video clip containing a persuasive claim

2. Text: an annotated transcript of the video clip

3. Control: no message shown

In the video condition, respondents were asked to watch a short video $(<1$ minute). In the text condition, respondents were instead asked to read a detailed transcript of this video. Finally, in the control condition, respondents were not shown any new information. We used a multi-stage randomization process to determine the treatment groups to which respondents were assigned. First, we randomly assigned respondents to four unique categories from the list of 15 high-level categories (e.g., immigration, climate change, taxes, see Table S2). Nested within each category was a set of persuasive messages (with between 1-6 messages per category). Respondents had a variable probability of being assigned to a given category, with the probability of assignment increasing in proportion to the total number of stimuli in that category. For example, if a given category included six out of the 48 stimuli, respondents had an initial probability of being assigned to that category of $p=0.13$, whereas if the category only contained two stimuli, respondents were assigned to that category with a probability of $p=0.04$. However, note that, because we sampled without replacement, respondents' exact probability of assignment to a given category was dependent on the other three categories to which they were assigned.

Second, respondents were randomly assigned to view one message from within each of their assigned categories, in order to avoid spillover across similar topics and outcome measures. Respondents had an equal probability of being assigned to each message within a given category. In expectation, each video should have been assigned to approximately 8-9\% of respondents, with respondents more frequently assigned to videos from less populous categories. However, given a finite sample size, the proportion of respondents assigned to each video was somewhat more variable - ranging from 7-10\%. Finally, respondents were randomly assigned to an experimental condition for each message (video, text, or control). Respondents were twice as likely to be assigned to one of the two experimental conditions versus the control, such that $p_{\text {video }}=p_{\text {text }}=0.4$ and $p_{\text {control }}=0.2$.

To implement this randomization scheme, we generated 50,000 potential treatment assignment combinations in $\mathrm{R}$ and randomly sampled one of these combinations for each respondent using PHP. We then imported this information into Qualtrics using a web service. A full description of the randomization procedure, including the $\mathrm{R}$ script used to simulate the treatment assignment process, is available here, and a summary is shown below (Figure S1). 


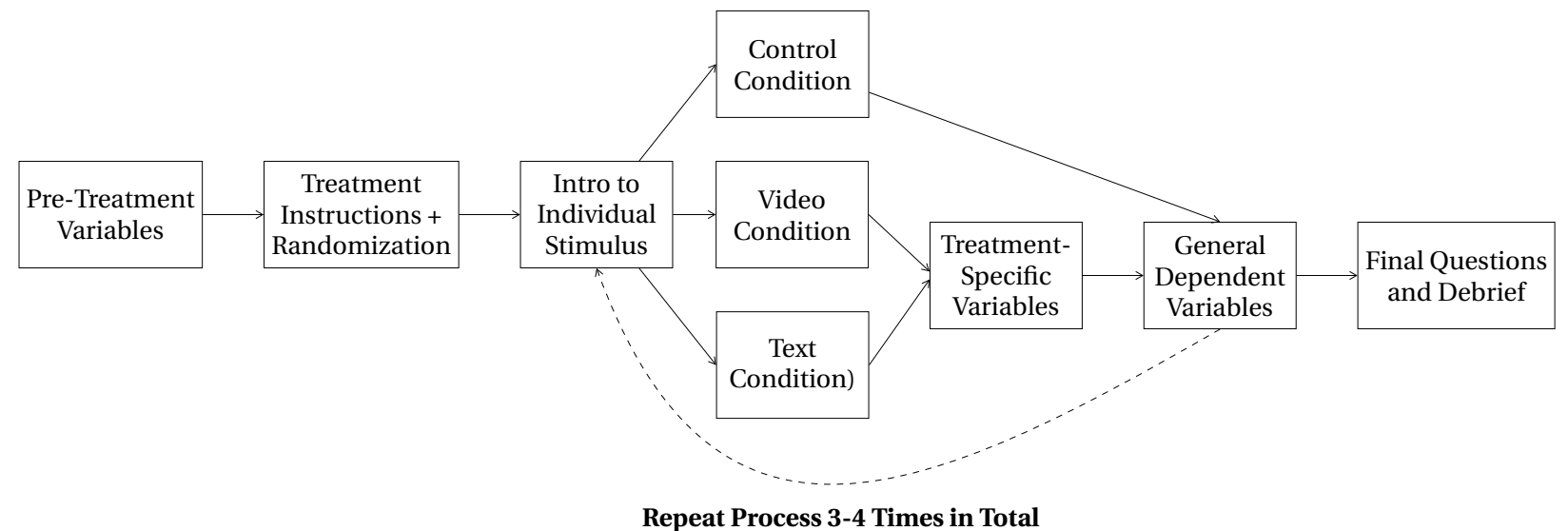

Figure S1: Summary of randomization procedure. Respondents in Study 1 were shown a random selection of four messages, whereas respondents in Study 2 were assigned to three messages.

\section{Study 2}

Study 2 followed a very similar procedure as Study 1 - just with a smaller set of slightly longer video clips (all $<2$ minutes in length). For this study, we randomly assigned respondents to view three messages, in random order, from a list of 24 possible stimuli (again using a within-subject design). As in Study 1, we first randomly assigned respondents to categories in this case, three unique categories from a list of five high-level categories (coronavirus vs. flu, preventative health strategies, science and technology, U.S. politics, or world politics, see Table S3). Given that all of the messages were about the COVID-19 pandemic, these categories were designated based on the structure and content of the dependent variables. Within each category was a set of persuasive messages (with between 3-7 messages per category).

Respondents again had a variable probability of being assigned to a given category, with the probability of assignment increasing in proportion to the number of messages within that category.

Second, respondents were randomly assigned to view one message from within each of their assigned categories. Respondents had an equal probability of being assigned to each message within a given category. In expectation, each video should have been assigned to approximately 11-15\% of respondents, with respondents more likely to be assigned to videos from less populous categories. Given a finite sample size, however, the proportion of respondents assigned to each video ranged from 10-16\%. Finally, respondents were randomly assigned to an experimental condition for each message (video, text, or control), using the same approach as in Study 1. To carry out this randomization procedure, we again generated 50,000 potential treatment assignment combinations in $R$, randomly sampled one of these combinations for each respondent using PHP, and finally imported this information into Qualtrics using a web service. A description of this process is available here. 


\subsection{Survey Questionnaire}

\section{Audiovisual Check}

After providing informed consent, respondents were asked to watch a sample clip to confirm that they were willing and able to watch video content. Respondents were asked two questions to determine whether they both watched and listened to this test clip. Respondents were required to answer both checks correctly in order to proceed to the rest of the survey. Respondents were given two chances to complete this step before being removed from the survey sample. $58.0 \%$ of respondents passed the technical checks in Study 1, as did $64.7 \%$ of respondents in Study 2.

- Instructions: "As part of this study, you may be required to watch videos with sound. Please confirm you are able to do so by watching the short video below and answering the questions on the next page.

Please watch carefully. If you do not answer these questions correctly, you will not be eligible to participate in this survey.

Before you start the clip, make sure your sound is on, and press play when you are ready to begin. Note that the video may take a few seconds to load."

- These instructions were accompanied by a link to a YouTube clip with a short advertisement for PG Tips tea.

- Visual check: "What was the name of the brand advertised in the video?"

$\left(1=\right.$ PG Tips ${ }^{*}, 2=$ Coca-Cola, $3=$ Duracell, $4=$ Cadbury, $5=$ Geico $)$

- Audio check: "Which of the following words was used in the video to describe the product?"

$(1=$ Delicious $*, 2=$ Healthy, $3=$ Surprising, $4=$ Bold, $5=$ Exciting $)$

- Follow-up instructions: (If respondents answered either the visual or audio check incorrectly) "You answered at least one of the questions wrong on the previous page.

Please watch the video one more time and then try again. If you do not answer these questions correctly a second time, the survey will immediately end, and you will not be eligible to participate.

You can watch the video as many times as you would like before proceeding to the next page. Before you start the clip, make sure your sound is on, and press play when you are ready to begin."

- After viewing this second set of instructions, respondents were provided a link to the same clip and were asked the same two questions as above. 


\section{Demographics}

After successfully completing the audiovisual check, respondents answered a series of demographic questions, displayed in the following order:

1. Gender: "What is your gender?"

$(1=$ Male, 2 = Female, $3=$ Other (please specify) $)$

2. Year of birth: "In what year were you born?"

(Drop-down menu, recoded into a measure of age in years)

3. State: "In what state do you currently reside?"

(Drop-down menu, recoded into a measure of census region)

4. Hispanic origin: “Are you of Hispanic, Latino, or Spanish origin?"

$(1=$ Yes, $0=$ No)

5. Race: "Please choose one or more races that you consider yourself to be.

For this survey, Hispanic origin is not a race. (Please select all that apply)"

(Check all that apply; 1 = White, $2=$ Black or African-American, $3=$ American Indian or Alaska Native, 4 = Asian, 5 = Native Hawaiian or other Pacific Islander, $6=$ Other (please specify))

6. Income: “Thinking back over the past year, what was your family's annual income?"

$(1=$ Less than $\$ 10,000,2=\$ 10,000-\$ 19,999,3=\$ 20,000-\$ 29,999,4=\$ 30,000-\$ 39,999,5=$ $\$ 40,000-\$ 49,999,6=\$ 50,000-\$ 74,999,7=\$ 75,000-\$ 99,999,8=\$ 100,000-\$ 149,999,9=$ $\$ 150,000$ or more, $10=$ Prefer not to say)

7. Education: "What is the highest level of education you have completed?" ( 1 = Did not graduate from high school, 2 = High school graduate, $3=$ Some college, but no degree, 4 = 2-year college degree, 5 = 4-year college degree, $6=$ Post-graduate degree (MA, $M B A, J D, P h D$, etc.))

8. Employment: "Which of the following best describes your current employment status?" ( 1 = Working full time now, 2 = Working part time now, $3=$ Temporarily laid off, $4=$ Unemployed, $5=$ Retired, $6=$ Permanently disabled, $7=$ Taking care of home or family, $8=$ Student, 9 = Other (please specify))

9. Partisanship, measured using a series of branching questions:

- "Generally speaking, do you consider yourself a..." ( 1 = Democrat, 2 = Republican, 3 = Independent, 4 = Other party)

- (If respondents selected either Democrat or Republican) "Would you call yourself a strong [Democrat/Republican] or a not very strong [Democrat/Republican]?" ( 1 = Strong [Democrat/Republican], 2 = Not very strong [Democrat/Republican]) 
- (If respondents selected either Independent or other party) "Do you think of yourself as closer to the Republican Party or to the Democratic Party?" ( 1 = Closer to the Republican Party, $2=$ Closer to the Democratic Party, $3=$ Neither $)$

10. Ideology, measured using a series of branching questions:

- "Generally speaking, do you usually think of yourself as a liberal, a conservative, a moderate, or haven't you thought much about this?" ( 1 = Liberal, 2 = Conservative, $3=$ Moderate, $4=$ Haven't thought much about it)

- (If respondents selected either liberal or conservative) "Would you call yourself a strong [liberal/conservative] or a not very strong [liberal/conservative]?" (1 = Strong [liberal/conservative], 2 = Not very strong [liberal/conservative])

- (If respondents selected either moderate or haven't thought much about it) "Do you think of yourself as closer to liberals or closer to conservatives?" ( 1 = Closer to liberals, $2=$ Closer to conservatives, $3=$ Neither $)$

\section{Pre-Treatment Moderator Variables}

Prior to the experimental portion of each study, we then measured several potential moderator variables (in addition to the standard demographic items described in the previous section).

1. Political knowledge, measured using a four-item battery of factual recall questions about political leaders and institutions (2). Starred responses were coded as correct. All other responses (including missing data) were coded as incorrect.

- "Whose responsibility is it to decide if a law is constitutional or not?" ( 1 = The President, 2 = Congress, 3 = The Supreme Court ${ }^{*}$; order randomized $)$

- "Whose responsibility is it to nominate judges to federal courts?" ( 1 = The President*, 2 = Congress, 3 = The Supreme Court; order randomized)

- "Do you know what job or political office is currently held by Nancy Pelosi? Is it:" ( 1 = Speaker of the House*, 2 = Treasury Secretary, 3 = Senate Majority Leader, $4=$ Justice of the Supreme Court, 5 = Governor of New Mexico; order randomized)

- "Do you know what job or political office is currently held by Janet Yellen? Is it:" ( 1 = Attorney General, 2 = Justice of the Supreme Court, $3=$ Treasury Secretary ${ }^{*}, 4=$ House Republican Leader, 5 = Secretary of State; order randomized)

2. Experiences with COVID-19, measured using the following four questions (Study 2 only, adapted from items used by Kaiser Family Foundation, the Pew Research Center, and YouGov):

- "How closely are you following news about the coronavirus pandemic?" ( 1 = Not at all closely, 2 = Not too closely, $3=$ Fairly closely, $4=$ Very closely) 
- "Do you personally know anyone who has tested positive for COVID-19? (Please select all that apply)"

$(1=$ Yes, me, 2 = Yes, a family member, $3=$ Yes, a close friend, $4=$ Yes, someone else, $5=$ No, 6 = Prefer not to say)

- (If respondents said they knew someone who had tested positive in the previous question) "Do you personally know anyone who has died due to complications from COVID-19? (Please select all that apply)"

$(1$ = Yes, a family member, 2 = Yes, a close friend, $3=$ Yes, someone else, $4=$ No, $5=$ Prefer not to say)

- "Have you received at least one dose of the COVID-19 vaccine?" $(1=Y e s, 0=N o)$

3. Cognitive reflection, measured using a four-item Cognitive Reflection Test $(3 ; 4 ; 5)$.

- "The ages of Mark and Adam add up to 28 years total. Mark is 20 years older than Adam. How many years old is Adam? (Please enter a number)" (Open-ended response; coded as correct if say 4, incorrect otherwise)

- "If it takes 10 seconds for 10 printers to print out 10 pages of paper, how many seconds will it take 50 printers to print out 50 pages of paper? (Please enter a number)"

(Open-ended response; coded as correct if say 10, incorrect otherwise)

- "On a loaf of bread, there is a patch of mold. Every day, the patch doubles in size. If it takes 40 days for the patch to cover the entire loaf of bread, how many days would it take for the patch to cover half of the loaf of bread? (Please enter a number)" (Open-ended response; coded as correct if say 39, incorrect otherwise)

- "If you're running a race, and you pass the person in second place, what place are you in? (Please enter a number and do not enter any letters)"

(Open-ended response; coded as correct if say 2, incorrect otherwise)

4. Digital literacy, measured by asking respondents to rate their level of familiarity with six computer- and Internet-related items (6):

- "How familiar are you with the following computer and Internet-related items?" ( 1 = Not at all familiar, 2 = Slightly familiar, $3=$ Moderately familiar, $4=$ Very familiar, 5 = Extremely familiar)

- Options (randomized order): Phishing, Hashtag, JPG, Malware, Cache, RSS

5. Attentiveness, measured using two instructional manipulation checks, or "screeners" (7). Starred responses were coded as correct. All other responses (including missing data) were coded as incorrect.

- "Help us keep track of who is paying attention to the survey. Please select 'Somewhat disagree' from the options below." 
( 1 = Strongly agree, $2=$ Agree, $3=$ Somewhat agree, $4=$ Neither agree nor disagree, $5=$ Somewhat disagree $*$, 6 = Disagree, $7=$ Strongly agree)

- "When a big news story breaks, people often go online to get up-to-the-minute details about what is going on. We want to know which websites people trust to get this information. We also want to know if people are paying attention to this question. To show that you've read this much, please ignore the question and select ABC News website and The Drudge Report as your two answers.

When there is a big news story, which is the one news website you would visit first? (Please choose only one)"

(Check all that apply; 1 = New York Times website, $2=$ Huffington Post, $3=$ Washington Post website, $4=$ CNN.com, $5=$ FoxNews.com, $6=$ MSNBC.com, $7=$ The Drudge Report ${ }^{*}, 8=$ Google News, $9=$ ABC News website $*$, 10=CBS News website, 11 = NBC News website, $12=$ Yahoo! News, $13=$ The Associated Press (AP) website, $14=$ Reuters website, 15 = National Public Radio (NPR) website, 16 = USA Today website, $17=$ New York Post Online, $18=$ None of these websites)

\section{Experimental Instructions}

Respondents then proceeded to the experimental portion of the study, which began with a brief set of instructions previewing the conditions to which respondents might be assigned. For Study 2, we also included a disclaimer about the timing of some of the messages, given that a number of the original YouTube videos were published early on in the pandemic and therefore may not have contained up-to-date public health guidance. In addition, because some respondents noted in Study 1 that they were confused about the interpretation of the believability items, we added a second set of instructions designed to help respondents better understand the intent of these questions.

- Study 1: "For the next part of the study, you will be asked questions about four different topics.

For some of these topics, you may be shown a short video. For others, you may be asked to read a written transcript. Finally, in some cases, you will just be asked to provide your opinion about the issue.

Note that these stories may take a few seconds to load."

- Study 2: "For the next part of the study, you will be asked questions about three different topics related to the coronavirus pandemic.

For some of these topics, you may be shown a short video. For others, you may be asked to read a written transcript. Note that some of these videos and transcripts were created in the early stages of the pandemic (i.e., in March 2020 or before) and so might not reflect current events or public health guidance. Finally, in some cases, you will just be asked to provide your opinion about the issue.

Note that these stories may take a few seconds to load." 
- Belief instructions: "Sometimes, what you see in a video or read in text isn't exactly what occurred in real life. During the survey, we will therefore ask you to tell us whether you think the events shown in a video clip or transcript actually took place - for instance, whether you believe that a speaker really made a particular claim.

As an example, you might be asked a question in the following format: 'To what extent do you believe the speaker actually said that the sky is blue?' When answering this question, we want to know whether you thought the person actually made this claim. In other words, do you think the speaker really said that the sky is blue, or was the video/transcript edited to make it seem like the speaker was saying something they never actually said?

We are not asking whether you agree with the statement or claim. Using our earlier example, we are not asking whether you personally think the sky is blue. We are just asking whether you think the speaker said the sky was blue. It is also possible that the words used in the survey question will not be the same exact phrases used in the video or transcript. In these cases, it doesn't matter whether the words were used verbatim. We just want to know whether you thought the general claim was made."

- Message-specific instructions: respondents were then shown an introduction to each message they were assigned, informing them about the condition to which they'd been assigned (video, text, or the control). After reading these instructions, respondents were administered the relevant treatment and were then asked to complete a series of outcome variables, described in the next section.

- Preamble: "Now, we're interested in hearing your thoughts about [topic]."

- Note: the pipe-in language for each individual message is listed below in Tables S4 and S5.

- Video intro: "You will find a video clip on the next page. Please watch this clip carefully. There will be a brief pause so that you can watch the clip. At the end of the pause, an arrow will appear at the bottom of the screen, allowing you to move to the next part of the survey.

Before you start the clip, make sure your sound is on, and press play when you are ready to begin. Note that the video may take a few seconds to load."

- Transcript intro: "You will find a transcript on the next page. Please read this transcript carefully. There will be a brief pause so that you can read the transcript. At the end of the pause, an arrow will appear at the bottom of the screen, allowing you to move to the next part of the survey.

Note that you may have to scroll in order to see the full transcript."

- For Study 2, several of the transcripts were split across multiple screens. In these cases, respondents were informed that the transcript would appear across two pages. 
- Respondents in the two treatment groups were then directed to the video or transcript. Each message was accompanied by a title and description (see Section 1.2). To encourage engagement with the content, we required respondents to stay on the treatment page for an extended period of time, equivalent to three-quarters the length of the full video clip.

\section{Outcome Variables}

For each message, we measured four sets of outcome variables (in the following order). With the exception of our measure of sharing intentions, the wording of all items varied across messages but followed the same basic format.

1. Believability of the content: "To what extent do you believe [the speaker] actually [made a particular claim from the story]?"

( 1 = Definitely did not happen, 5 = Definitely happened $)$

- Note that this measure was only shown to respondents in the two treatment conditions (video or text).

2. Attitudinal persuasion: "Please rate the extent to which you agree or disagree with the following statement: [Persuasive claim from the story]?"

( 1 = Strongly disagree, 5 = Strongly agree $)$

3. Personal engagement: measured using two items.

- Personal importance (Study 1 only): "How important is the issue of [topic] to you, relative to other issues?"

$(1$ = Not at all important, 5 = Extremely important $)$

- Interest in learning more: "To what extent are you interested in learning more about [topic]?"

$(1=$ Not at all interested, $5=$ Extremely interested $)$

4. Sharing intentions: "How likely would you be to share the story you just saw with a friend or colleague?"

$(1=$ Not at all likely, 5 = Extremely likely $)$

- Note that this measure was only shown to respondents in the two treatment conditions (video or text).

For the questions that vary across individual stimuli, the exact wording for each message is listed below (Table S4 for Study 1, Table S5 for Study 2). 


\begin{tabular}{|c|c|c|c|c|c|c|}
\hline Video ID & Video Title & Topic & Belief Item & Persuasion Item & Importance Item & Engagement Item \\
\hline 1000 & $\begin{array}{l}\text { Abigail } \\
\text { Disney }\end{array}$ & tax policy & $\begin{array}{l}\text { To what extent do you believe } \\
\text { Abigail Disney actually said tax } \\
\text { cuts disproportionately benefit } \\
\text { the wealthy? }\end{array}$ & $\begin{array}{l}\text { Recent tax cuts have } \\
\text { benefitted wealthy } \\
\text { Americans more than } \\
\text { others. }\end{array}$ & $\begin{array}{c}\text { How important is the issue } \\
\text { of tax cuts to you, relative to } \\
\text { other issues? }\end{array}$ & $\begin{array}{l}\text { To what extent are you } \\
\text { interested in learning more } \\
\text { about tax cuts? }\end{array}$ \\
\hline 1001 & $\begin{array}{l}\text { Angry Young } \\
\text { Man }\end{array}$ & $\begin{array}{l}\text { corporate } \\
\text { lobbying }\end{array}$ & $\begin{array}{l}\text { To what extent do you believe the } \\
\text { speaker actually said corporations } \\
\text { have too much power over } \\
\text { politics? }\end{array}$ & $\begin{array}{l}\text { Major corporations in the } \\
\text { U.S. have too much power } \\
\text { over politics. }\end{array}$ & $\begin{array}{l}\text { How important is the issue } \\
\text { of corporate lobbying to } \\
\text { you, relative to other issues? }\end{array}$ & $\begin{array}{l}\text { To what extent are you } \\
\text { interested in learning more } \\
\text { about corporate lobbying? }\end{array}$ \\
\hline 1002 & $\begin{array}{l}\text { Autobarn } \\
\text { Minimum } \\
\text { Wage }\end{array}$ & $\begin{array}{l}\text { the minimum } \\
\text { wage }\end{array}$ & $\begin{array}{l}\text { To what extent do you believe the } \\
\text { business owners actually said they } \\
\text { support raising the minimum } \\
\text { wage? }\end{array}$ & $\begin{array}{l}\text { The minimum wage should } \\
\text { be increased to } \$ 15.00 / \text { hour. }\end{array}$ & $\begin{array}{l}\text { How important is the issue } \\
\text { of the minimum wage to } \\
\text { you, relative to other issues? }\end{array}$ & $\begin{array}{l}\text { To what extent are you } \\
\text { interested in learning more } \\
\text { about the minimum wage? }\end{array}$ \\
\hline 1003 & Ben Cohen & tax policy & $\begin{array}{l}\text { To what extent do you believe Ben } \\
\text { Cohen actually said tax cuts } \\
\text { disproportionately benefit the } \\
\text { wealthy? }\end{array}$ & $\begin{array}{l}\text { Recent tax cuts have } \\
\text { benefitted wealthy } \\
\text { Americans more than } \\
\text { others. }\end{array}$ & $\begin{array}{l}\text { How important is the issue } \\
\text { of tax cuts to you, relative to } \\
\text { other issues? }\end{array}$ & $\begin{array}{l}\text { To what extent are you } \\
\text { interested in learning more } \\
\text { about tax cuts? }\end{array}$ \\
\hline 1004 & $\begin{array}{l}\text { Bob's Crab } \\
\text { Shack }\end{array}$ & $\begin{array}{l}\text { the minimum } \\
\text { wage }\end{array}$ & $\begin{array}{l}\text { To what extent do you believe the } \\
\text { business owner actually said he } \\
\text { supports raising the minimum } \\
\text { wage? }\end{array}$ & $\begin{array}{l}\text { The minimum wage should } \\
\text { be increased to } \$ 15.00 / \text { hour. }\end{array}$ & $\begin{array}{l}\text { How important is the issue } \\
\text { of the minimum wage to } \\
\text { you, relative to other issues? }\end{array}$ & $\begin{array}{l}\text { To what extent are you } \\
\text { interested in learning more } \\
\text { about the minimum wage? }\end{array}$ \\
\hline 1005 & $\begin{array}{l}\text { Carbon } \\
\text { Pollution }\end{array}$ & $\begin{array}{l}\text { climate } \\
\text { change }\end{array}$ & $\begin{array}{l}\text { To what extent do you believe the } \\
\text { video actually said carbon } \\
\text { pollution makes food less healthy? }\end{array}$ & $\begin{array}{l}\text { The U.S. should take steps } \\
\text { to reduce its carbon } \\
\text { emissions. }\end{array}$ & $\begin{array}{l}\text { How important is the issue } \\
\text { of climate change to you, } \\
\text { relative to other issues? }\end{array}$ & $\begin{array}{c}\text { To what extent are you } \\
\text { interested in learning more } \\
\text { about ways to reduce } \\
\text { carbon emissions? }\end{array}$ \\
\hline 1006 & $\begin{array}{c}\text { Climate } \\
\text { Science with } \\
\text { Leo }\end{array}$ & $\begin{array}{l}\text { climate } \\
\text { change }\end{array}$ & $\begin{array}{l}\text { To what extent do you believe } \\
\text { Leonardo DiCaprio actually said } \\
\text { most scientists believe humans } \\
\text { are contributing to climate } \\
\text { change? }\end{array}$ & $\begin{array}{l}\text { Human activity contributes } \\
\text { to climate change. }\end{array}$ & $\begin{array}{l}\text { How important is the issue } \\
\text { of climate change to you, } \\
\text { relative to other issues? }\end{array}$ & $\begin{array}{c}\text { To what extent are you } \\
\text { interested in learning more } \\
\text { about the scientific } \\
\text { consensus on climate } \\
\text { change? }\end{array}$ \\
\hline 1007 & $\begin{array}{l}\text { Colorado and } \\
\text { Birth Control }\end{array}$ & $\begin{array}{l}\text { reproductive } \\
\text { health }\end{array}$ & $\begin{array}{l}\text { To what extent do you believe the } \\
\text { video actually said access to birth } \\
\text { control saves states money? }\end{array}$ & $\begin{array}{l}\text { The U.S. should increase } \\
\text { access to birth control. }\end{array}$ & $\begin{array}{l}\text { How important is the issue } \\
\text { of reproductive health to } \\
\text { you, relative to other issues? }\end{array}$ & $\begin{array}{c}\text { To what extent are you } \\
\text { interested in learning more } \\
\text { about access to reproductive } \\
\text { health services? }\end{array}$ \\
\hline 1008 & $\begin{array}{l}\text { Cows and } \\
\text { Seaweed }\end{array}$ & $\begin{array}{l}\text { climate } \\
\text { change }\end{array}$ & $\begin{array}{c}\text { To what extent do you believe the } \\
\text { video actually said farmers should } \\
\text { feed cows seaweed to combat } \\
\text { climate change? }\end{array}$ & $\begin{array}{c}\text { Farmers who raise cows } \\
\text { should adopt more } \\
\text { sustainable farming } \\
\text { practices. }\end{array}$ & $\begin{array}{l}\text { How important is the issue } \\
\text { of climate change to you, } \\
\text { relative to other issues? }\end{array}$ & $\begin{array}{c}\text { To what extent are you } \\
\text { interested in learning more } \\
\text { about sustainable farming } \\
\text { practices? }\end{array}$ \\
\hline 1009 & $\begin{array}{l}\text { Defunding } \\
\text { Planned } \\
\text { Parenthood }\end{array}$ & $\begin{array}{l}\text { reproductive } \\
\text { health }\end{array}$ & $\begin{array}{c}\text { To what extent do you believe } \\
\text { actress Kate Walsh actually said } \\
\text { defunding Planned Parenthood } \\
\text { would cause a national healthcare } \\
\text { disaster? }\end{array}$ & $\begin{array}{l}\text { Planned Parenthood should } \\
\text { receive funding from the } \\
\text { federal government. }\end{array}$ & $\begin{array}{l}\text { How important is the issue } \\
\text { of reproductive health to } \\
\text { you, relative to other issues? }\end{array}$ & $\begin{array}{l}\text { To what extent are you } \\
\text { interested in learning more } \\
\text { about funding for Planned } \\
\text { Parenthood? }\end{array}$ \\
\hline 1010 & $\begin{array}{l}\text { Eddie // } \\
\text { Veteran } \\
\text { Affairs }\end{array}$ & $\begin{array}{l}\text { support for } \\
\text { veterans }\end{array}$ & $\begin{array}{c}\text { To what extent do you believe the } \\
\text { speaker actually said he had a bad } \\
\text { experience with the Department } \\
\text { of Veteran Affairs (VA)? }\end{array}$ & $\begin{array}{l}\text { Funding for the Department } \\
\text { of Veteran Affairs (VA) } \\
\text { should be increased. }\end{array}$ & $\begin{array}{l}\text { How important is the issue } \\
\text { of support for veterans to } \\
\text { you, relative to other issues? }\end{array}$ & $\begin{array}{c}\text { To what extent are you } \\
\text { interested in learning more } \\
\text { about funding for veterans' } \\
\text { services? }\end{array}$ \\
\hline 1011 & $\begin{array}{l}\text { Education } \\
\text { Privatization }\end{array}$ & $\begin{array}{l}\text { public } \\
\text { education }\end{array}$ & $\begin{array}{l}\text { To what extent do you believe the } \\
\text { speaker actually said education } \\
\text { privatization is harmful to public } \\
\text { schools? }\end{array}$ & $\begin{array}{l}\text { Public schools in the U.S. } \\
\text { should be privatized. } \\
\text { (Reverse-coded) }\end{array}$ & $\begin{array}{l}\text { How important is the issue } \\
\text { of education privatization to } \\
\text { you, relative to other issues? }\end{array}$ & $\begin{array}{c}\text { To what extent are you } \\
\text { interested in learning more } \\
\text { about education } \\
\text { privatization? }\end{array}$ \\
\hline 1012 & $\begin{array}{c}\text { Factory } \\
\text { Worker Larry } \\
\text { // Healthcare }\end{array}$ & $\begin{array}{c}\text { corporations' } \\
\text { treatment of } \\
\text { their } \\
\text { employees }\end{array}$ & $\begin{array}{l}\text { To what extent do you believe the } \\
\text { speaker actually said the } \\
\text { Honeywell Corporation took away } \\
\text { his retirement benefits? }\end{array}$ & $\begin{array}{l}\text { Employers generally pursue } \\
\text { profits at the expense of } \\
\text { their employees. }\end{array}$ & $\begin{array}{c}\text { How important is the issue } \\
\text { of corporations' treatment } \\
\text { of employees to you, relative } \\
\text { to other issues? }\end{array}$ & $\begin{array}{l}\text { To what extent are you } \\
\text { interested in learning more } \\
\text { about corporations' } \\
\text { treatment of their } \\
\text { employees? }\end{array}$ \\
\hline 1013 & $\begin{array}{c}\text { Factory } \\
\text { Worker Larry } \\
\text { // Jobs } \\
\text { Overseas }\end{array}$ & $\begin{array}{c}\text { corporations' } \\
\text { treatment of } \\
\text { their } \\
\text { employees }\end{array}$ & $\begin{array}{l}\text { To what extent do you believe the } \\
\text { speaker actually said the } \\
\text { Honeywell Corporation sent jobs } \\
\text { overseas? }\end{array}$ & $\begin{array}{l}\text { Employers generally pursue } \\
\text { profits at the expense of } \\
\text { their employees. }\end{array}$ & $\begin{array}{l}\text { How important is the issue } \\
\text { of job outsourcing to you, } \\
\text { relative to other issues? }\end{array}$ & $\begin{array}{l}\text { To what extent are you } \\
\text { interested in learning more } \\
\text { about the outsourcing of } \\
\text { jobs overseas? }\end{array}$ \\
\hline 1014 & $\begin{array}{l}\text { Farmer and } \\
\text { Tax Cuts }\end{array}$ & tax policy & $\begin{array}{c}\text { To what extent do you believe the } \\
\text { farmer actually said tax cuts } \\
\text { disproportionately benefit large } \\
\text { corporations? }\end{array}$ & $\begin{array}{c}\text { Recent tax cuts have } \\
\text { benefitted large } \\
\text { corporations more than } \\
\text { other groups. }\end{array}$ & $\begin{array}{c}\text { How important is the issue } \\
\text { of tax cuts to you, relative to } \\
\text { other issues? }\end{array}$ & $\begin{array}{c}\text { To what extent are you } \\
\text { interested in learning more } \\
\text { about tax cuts? }\end{array}$ \\
\hline 1015 & $\begin{array}{l}\text { Father } \\
\text { Enraged over } \\
\text { Trumpcare }\end{array}$ & healthcare & $\begin{array}{l}\text { To what extent do you believe the } \\
\text { speaker actually criticized Trump } \\
\text { for making cuts to the Affordable } \\
\text { Care Act (ACA)? }\end{array}$ & $\begin{array}{l}\text { The Affordable Care Act } \\
\text { (ACA) should be repealed. } \\
\text { (Reverse-coded) }\end{array}$ & $\begin{array}{l}\text { How important is the issue } \\
\text { of affordable healthcare to } \\
\text { you, relative to other issues? }\end{array}$ & $\begin{array}{c}\text { To what extent are you } \\
\text { interested in learning more } \\
\text { about changes to the } \\
\text { Affordable Care Act (ACA)? }\end{array}$ \\
\hline 1016 & $\begin{array}{l}\text { Fox News and } \\
\text { Taxes }\end{array}$ & tax policy & $\begin{array}{l}\text { To what extent do you believe } \\
\text { Trump actually said he would } \\
\text { close tax loopholes that benefit } \\
\text { the wealthy? }\end{array}$ & $\begin{array}{l}\text { The government should } \\
\text { close tax loopholes for } \\
\text { wealthy individuals. }\end{array}$ & $\begin{array}{l}\text { How important is the issue } \\
\text { of tax policy to you, relative } \\
\text { to other issues? }\end{array}$ & $\begin{array}{l}\text { To what extent are you } \\
\text { interested in learning more } \\
\text { about tax policy? }\end{array}$ \\
\hline 1017 & $\begin{array}{l}\text { Get the } \\
\text { American } \\
\text { Dream Back } \\
\text { on Track } \\
\end{array}$ & tax policy & $\begin{array}{l}\text { To what extent do you believe the } \\
\text { speaker actually said tax cuts for } \\
\text { the wealthy reduce funding for } \\
\text { infrastructure projects? }\end{array}$ & $\begin{array}{c}\text { Taxes should be raised on } \\
\text { the wealthiest Americans in } \\
\text { order to fund infrastructure } \\
\text { projects. }\end{array}$ & $\begin{array}{l}\text { How important is the issue } \\
\text { of infrastructure funding to } \\
\text { you, relative to other issues? }\end{array}$ & $\begin{array}{l}\text { To what extent are you } \\
\text { interested in learning more } \\
\text { about funding for } \\
\text { infrastructure projects? }\end{array}$ \\
\hline 1018 & Gun Control & $\begin{array}{l}\text { gun laws in } \\
\text { the United } \\
\text { States }\end{array}$ & $\begin{array}{l}\text { To what extent do you believe the } \\
\text { speaker actually called for stricter } \\
\text { regulations of gun ownership? }\end{array}$ & $\begin{array}{l}\text { There should be stricter gun } \\
\text { laws in the United States. }\end{array}$ & $\begin{array}{l}\text { How important is the issue } \\
\text { of gun control to you, } \\
\text { relative to other issues? }\end{array}$ & $\begin{array}{l}\text { To what extent are you } \\
\text { interested in learning more } \\
\text { about gun laws in the } \\
\text { United States? }\end{array}$ \\
\hline 1019 & $\begin{array}{c}\text { Income } \\
\text { Inequality // } \\
\text { Craig \#1 }\end{array}$ & $\begin{array}{l}\text { income } \\
\text { inequality }\end{array}$ & $\begin{array}{l}\text { To what extent do you believe the } \\
\text { speaker actually said billionaires } \\
\text { and lobbyists seek to divide the } \\
\text { working class? }\end{array}$ & $\begin{array}{l}\text { The government should take } \\
\text { steps to reduce differences } \\
\text { in income between rich and } \\
\text { poor people. }\end{array}$ & $\begin{array}{l}\text { How important is the issue } \\
\text { of income inequality to you, } \\
\text { relative to other issues? }\end{array}$ & $\begin{array}{c}\text { To what extent are you } \\
\text { interested in learning more } \\
\text { about ways to reduce } \\
\text { income differences between } \\
\text { rich and poor people? }\end{array}$ \\
\hline 1020 & $\begin{array}{l}\text { KFC Vet and } \\
\text { Minimum } \\
\text { Wage }\end{array}$ & $\begin{array}{l}\text { the minimum } \\
\text { wage }\end{array}$ & $\begin{array}{l}\text { To what extent do you believe the } \\
\text { KFC worker actually said he } \\
\text { supports raising the minimum } \\
\text { wage? }\end{array}$ & $\begin{array}{l}\text { The minimum wage should } \\
\text { be increased to } \$ 15.00 / \text { hour. }\end{array}$ & $\begin{array}{l}\text { How important is the issue } \\
\text { of the minimum wage to } \\
\text { you, relative to other issues? }\end{array}$ & $\begin{array}{l}\text { To what extent are you } \\
\text { interested in learning more } \\
\text { about the minimum wage? }\end{array}$ \\
\hline
\end{tabular}




\begin{tabular}{|c|c|c|c|c|c|c|}
\hline Video ID & Video Title & Topic & Belief Item & Persuasion Item & Importance Item & Engagement Item \\
\hline 1021 & $\begin{array}{l}\text { Main Street } \\
\text { Economic } \\
\text { Development }\end{array}$ & $\begin{array}{l}\text { economic } \\
\text { support for } \\
\text { small } \\
\text { businesses }\end{array}$ & $\begin{array}{c}\text { To what extent do you believe the } \\
\text { speaker actually said Main Street } \\
\text { businesses are vital to economic } \\
\text { growth? }\end{array}$ & $\begin{array}{l}\text { The government should } \\
\text { invest more in small } \\
\text { businesses. }\end{array}$ & $\begin{array}{l}\text { How important is the issue } \\
\text { of economic support for } \\
\text { small businesses to you, } \\
\text { relative to other issues? }\end{array}$ & $\begin{array}{c}\text { To what extent are you } \\
\text { interested in learning more } \\
\text { about economic support for } \\
\text { small businesses? }\end{array}$ \\
\hline 1022 & $\begin{array}{l}\text { Main Street } \\
\text { Investment }\end{array}$ & $\begin{array}{l}\text { economic } \\
\text { support for } \\
\text { small } \\
\text { businesses }\end{array}$ & $\begin{array}{c}\text { To what extent do you believe the } \\
\text { speaker actually said people } \\
\text { should invest in Main Street } \\
\text { businesses first? }\end{array}$ & $\begin{array}{l}\text { The government should } \\
\text { invest more in small } \\
\text { businesses. }\end{array}$ & $\begin{array}{l}\text { How important is the issue } \\
\text { of economic support for } \\
\text { small businesses to you, } \\
\text { relative to other issues? }\end{array}$ & $\begin{array}{c}\text { To what extent are you } \\
\text { interested in learning more } \\
\text { about economic support for } \\
\text { small businesses? }\end{array}$ \\
\hline 1023 & $\begin{array}{l}\text { Marijuana } \\
\text { Legalization }\end{array}$ & $\begin{array}{c}\text { marijuana } \\
\text { legalization }\end{array}$ & $\begin{array}{l}\text { To what extent do you believe the } \\
\text { speaker actually said marijuana } \\
\text { should be decriminalized? }\end{array}$ & $\begin{array}{l}\text { Marijuana use should be } \\
\text { legal in all U.S. states. }\end{array}$ & $\begin{array}{l}\text { How important is the issue } \\
\text { of marijuana legalization to } \\
\text { you, relative to other issues? }\end{array}$ & $\begin{array}{c}\text { To what extent are you } \\
\text { interested in learning more } \\
\text { about marijuana } \\
\text { legalization? }\end{array}$ \\
\hline 1024 & $\begin{array}{l}\text { Massachusetts } \\
\text { Nurse }\end{array}$ & $\begin{array}{l}\text { paid sick } \\
\text { leave }\end{array}$ & $\begin{array}{l}\text { To what extent do you believe the } \\
\text { speaker actually said a lack of } \\
\text { paid sick leave harms children } \\
\text { and their families? }\end{array}$ & $\begin{array}{l}\text { The government should } \\
\text { require employers to offer } \\
\text { paid time off to workers } \\
\text { whose family members are } \\
\text { sick. }\end{array}$ & $\begin{array}{l}\text { How important is the issue } \\
\text { of paid sick leave to you, } \\
\text { relative to other issues? }\end{array}$ & $\begin{array}{l}\text { To what extent are you } \\
\text { interested in learning more } \\
\text { about paid sick leave? }\end{array}$ \\
\hline 1025 & Net Neutrality & $\begin{array}{l}\text { Internet } \\
\text { regulation }\end{array}$ & $\begin{array}{l}\text { To what extent do you believe the } \\
\text { speaker actually said net } \\
\text { neutrality is a bipartisan issue? }\end{array}$ & $\begin{array}{l}\text { Internet service providers } \\
\text { should be allowed to adjust } \\
\text { the quality and/or speed of } \\
\text { Internet content based on } \\
\text { fees charged to companies. } \\
\text { (Reverse-coded) }\end{array}$ & $\begin{array}{l}\text { How important is the issue } \\
\text { of Internet regulation to } \\
\text { you, relative to other issues? }\end{array}$ & $\begin{array}{l}\text { To what extent are you } \\
\text { interested in learning more } \\
\text { about policies related to } \\
\text { Internet regulation? }\end{array}$ \\
\hline 1026 & NJ Nurses & $\begin{array}{l}\text { children's } \\
\text { healthcare }\end{array}$ & $\begin{array}{l}\text { To what extent do you believe the } \\
\text { school nurses actually said they } \\
\text { are the primary healthcare } \\
\text { providers for many students? }\end{array}$ & $\begin{array}{l}\text { Funding for school nurses } \\
\text { should be increased. }\end{array}$ & $\begin{array}{l}\text { How important is the issue } \\
\text { of children's healthcare to } \\
\text { you, relative to other issues? }\end{array}$ & $\begin{array}{l}\text { To what extent are you } \\
\text { interested in learning more } \\
\text { about policies related to } \\
\text { children's healthcare? }\end{array}$ \\
\hline 1027 & $\begin{array}{l}\text { Nurse and } \\
\text { ACA }\end{array}$ & healthcare & $\begin{array}{l}\text { To what extent do you believe the } \\
\text { Republican nurse actually said } \\
\text { she supports the Affordable Care } \\
\text { Act (ACA)? }\end{array}$ & $\begin{array}{l}\text { The Affordable Care Act } \\
\text { (ACA) should be repealed. } \\
\text { (Reverse-coded) }\end{array}$ & $\begin{array}{l}\text { How important is the issue } \\
\text { of affordable healthcare to } \\
\text { you, relative to other issues? }\end{array}$ & $\begin{array}{c}\text { To what extent are you } \\
\text { interested in learning more } \\
\text { about changes to the } \\
\text { Affordable Care Act (ACA)? }\end{array}$ \\
\hline 1028 & $\begin{array}{l}\text { Oklahoma } \\
\text { Teachers }\end{array}$ & $\begin{array}{l}\text { public } \\
\text { education }\end{array}$ & $\begin{array}{l}\text { To what extent do you believe the } \\
\text { teachers actually said they work } \\
\text { multiple jobs to make ends meet? }\end{array}$ & $\begin{array}{l}\text { Public school teachers } \\
\text { should be paid a higher } \\
\text { salary. }\end{array}$ & $\begin{array}{l}\text { How important is the issue } \\
\text { of funding for public } \\
\text { schools to you, relative to } \\
\text { other issues? }\end{array}$ & $\begin{array}{c}\text { To what extent are you } \\
\text { interested in learning more } \\
\text { about funding for public } \\
\text { schools? }\end{array}$ \\
\hline 1029 & Opioid Crisis & $\begin{array}{c}\text { opioid } \\
\text { addiction }\end{array}$ & $\begin{array}{c}\text { To what extent do you believe the } \\
\text { speaker actually said he was able } \\
\text { to successfully recover from } \\
\text { opioid addiction? }\end{array}$ & $\begin{array}{c}\text { The government should } \\
\text { devote more resources to } \\
\text { addressing the opioid } \\
\text { epidemic. }\end{array}$ & $\begin{array}{l}\text { How important is the issue } \\
\text { of opioid addiction to you, } \\
\text { relative to other issues? }\end{array}$ & $\begin{array}{c}\text { To what extent are you } \\
\text { interested in learning more } \\
\text { about support for opioid } \\
\text { addiction? }\end{array}$ \\
\hline 1030 & $\begin{array}{l}\text { Paid Family } \\
\text { Leave (Jamie) }\end{array}$ & $\begin{array}{l}\text { paid family } \\
\text { leave }\end{array}$ & $\begin{array}{c}\text { To what extent do you believe the } \\
\text { speaker actually said paid family } \\
\text { leave is better for the baby's } \\
\text { health? }\end{array}$ & $\begin{array}{l}\text { The government should } \\
\text { require employers to } \\
\text { provide their workers with } \\
\text { paid family leave. }\end{array}$ & $\begin{array}{l}\text { How important is the issue } \\
\text { of paid family leave to you, } \\
\text { relative to other issues? }\end{array}$ & $\begin{array}{l}\text { To what extent are you } \\
\text { interested in learning more } \\
\text { about paid family leave? }\end{array}$ \\
\hline 1031 & $\begin{array}{l}\text { Paid Family } \\
\text { Leave (Tara) }\end{array}$ & $\begin{array}{l}\text { paid family } \\
\text { leave }\end{array}$ & $\begin{array}{l}\text { To what extent do you believe the } \\
\text { speaker actually said paid family } \\
\text { leave is better for the economy? }\end{array}$ & $\begin{array}{l}\text { The government should } \\
\text { require employers to } \\
\text { provide their workers with } \\
\text { paid family leave. } \\
\end{array}$ & $\begin{array}{l}\text { How important is the issue } \\
\text { of paid family leave to you, } \\
\text { relative to other issues? }\end{array}$ & $\begin{array}{l}\text { To what extent are you } \\
\text { interested in learning more } \\
\text { about paid family leave? }\end{array}$ \\
\hline 1032 & $\begin{array}{l}\text { Payday } \\
\text { Lending }\end{array}$ & $\begin{array}{l}\text { personal } \\
\text { finance }\end{array}$ & $\begin{array}{l}\text { To what extent do you believe the } \\
\text { speaker actually said people } \\
\text { should avoid payday lenders? }\end{array}$ & $\begin{array}{l}\text { There should be more } \\
\text { government oversight of } \\
\text { financial companies, such } \\
\text { as payday lenders. }\end{array}$ & $\begin{array}{l}\text { How important is the issue } \\
\text { of personal finance to you, } \\
\text { relative to other issues? }\end{array}$ & $\begin{array}{c}\text { To what extent are you } \\
\text { interested in learning more } \\
\text { about payday lenders? }\end{array}$ \\
\hline 1033 & $\begin{array}{l}\text { Protect our } \\
\text { People at } \\
\text { Home }\end{array}$ & healthcare & $\begin{array}{l}\text { To what extent do you believe the } \\
\text { speaker actually said the U.S. } \\
\text { should give all Americans access } \\
\text { to affordable healthcare? }\end{array}$ & $\begin{array}{l}\text { The government should } \\
\text { provide affordable } \\
\text { healthcare coverage to all } \\
\text { Americans. }\end{array}$ & $\begin{array}{l}\text { How important is the issue } \\
\text { of affordable healthcare to } \\
\text { you, relative to other issues? }\end{array}$ & $\begin{array}{l}\text { To what extent are you } \\
\text { interested in learning more } \\
\text { about policies related to } \\
\text { affordable healthcare? }\end{array}$ \\
\hline 1034 & $\begin{array}{c}\text { Real } \\
\text { Prosperity }\end{array}$ & $\begin{array}{l}\text { paid family } \\
\text { leave }\end{array}$ & $\begin{array}{l}\text { To what extent do you believe the } \\
\text { speaker actually said she had to } \\
\text { go back to work one week after } \\
\text { giving birth? }\end{array}$ & $\begin{array}{l}\text { The government should } \\
\text { require employers to } \\
\text { provide their workers with } \\
\text { paid family leave. }\end{array}$ & $\begin{array}{l}\text { How important is the issue } \\
\text { of paid family leave to you, } \\
\text { relative to other issues? }\end{array}$ & $\begin{array}{l}\text { To what extent are you } \\
\text { interested in learning more } \\
\text { about paid family leave? }\end{array}$ \\
\hline 1035 & $\begin{array}{l}\text { Russian } \\
\text { Interference }\end{array}$ & $\begin{array}{l}\text { election ad- } \\
\text { ministration } \\
\text { in the United } \\
\text { States }\end{array}$ & $\begin{array}{l}\text { To what extent do you believe the } \\
\text { veterans actually said Trump } \\
\text { should be held accountable for } \\
\text { Russian interference in American } \\
\text { elections? }\end{array}$ & $\begin{array}{l}\text { The government should do } \\
\text { more to prevent Russian } \\
\text { interference in American } \\
\text { elections. }\end{array}$ & $\begin{array}{l}\text { How important is the issue } \\
\text { of election interference to } \\
\text { you, relative to other issues? }\end{array}$ & $\begin{array}{l}\text { To what extent are you } \\
\text { interested in learning more } \\
\text { about Russian interference } \\
\text { in American elections? }\end{array}$ \\
\hline 1036 & $\begin{array}{l}\text { Stop with the } \\
\text { Games }\end{array}$ & $\begin{array}{l}\text { support for } \\
\text { working } \\
\text { Americans }\end{array}$ & $\begin{array}{l}\text { To what extent do you believe the } \\
\text { speaker actually said politicians } \\
\text { aren't doing enough to help } \\
\text { working Americans? }\end{array}$ & $\begin{array}{l}\text { The government should } \\
\text { provide more economic } \\
\text { support to working } \\
\text { Americans. }\end{array}$ & $\begin{array}{c}\text { How important is the issue } \\
\text { of support for working } \\
\text { Americans to you, relative to } \\
\text { other issues? }\end{array}$ & $\begin{array}{c}\text { To what extent are you } \\
\text { interested in learning more } \\
\text { about policies to support } \\
\text { working Americans? }\end{array}$ \\
\hline 1037 & $\begin{array}{l}\text { Three Million } \\
\text { Dollars }\end{array}$ & healthcare & $\begin{array}{l}\text { To what extent do you believe the } \\
\text { speaker actually said the U.S. } \\
\text { should give all Americans access } \\
\text { to affordable healthcare? }\end{array}$ & $\begin{array}{l}\text { The government should } \\
\text { provide affordable } \\
\text { healthcare coverage to all } \\
\text { Americans. }\end{array}$ & $\begin{array}{l}\text { How important is the issue } \\
\text { of affordable healthcare to } \\
\text { you, relative to other issues? }\end{array}$ & $\begin{array}{l}\text { To what extent are you } \\
\text { interested in learning more } \\
\text { about policies related to } \\
\text { affordable healthcare? }\end{array}$ \\
\hline 1038 & $\begin{array}{l}\text { Tim Cook and } \\
\text { DACA }\end{array}$ & immigration & $\begin{array}{l}\text { To what extent do you believe } \\
\text { Apple CEO Tim Cook actually said } \\
\text { immigrants who came to the U.S. } \\
\text { as children should be allowed to } \\
\text { stay in the country? }\end{array}$ & $\begin{array}{l}\text { The U.S. should create a } \\
\text { path to citizenship for } \\
\text { undocumented immigrants } \\
\text { brought to the country as } \\
\text { children. }\end{array}$ & $\begin{array}{l}\text { How important is the issue } \\
\text { of immigration to you, } \\
\text { relative to other issues? }\end{array}$ & $\begin{array}{l}\text { To what extent are you } \\
\text { interested in learning more } \\
\text { about the Deferred Action } \\
\text { for Childhood Arrivals } \\
\text { (DACA) program? }\end{array}$ \\
\hline 1039 & $\begin{array}{l}\text { Time for a } \\
\text { Real Change }\end{array}$ & $\begin{array}{l}\text { support for } \\
\text { the middle } \\
\text { class }\end{array}$ & $\begin{array}{l}\text { To what extent do you believe the } \\
\text { speaker actually said politicians } \\
\text { don't do enough to support the } \\
\text { middle class? }\end{array}$ & $\begin{array}{l}\text { The government should } \\
\text { provide more economic } \\
\text { support to the middle class. }\end{array}$ & $\begin{array}{l}\text { How important is the issue } \\
\text { of support for the middle } \\
\text { class to you, relative to other } \\
\text { issues? }\end{array}$ & $\begin{array}{c}\text { To what extent are you } \\
\text { interested in learning more } \\
\text { about policies to support } \\
\text { the middle class? }\end{array}$ \\
\hline 1040 & $\begin{array}{l}\text { Tuition Free } \\
\text { College }\end{array}$ & $\begin{array}{l}\text { college } \\
\text { education }\end{array}$ & $\begin{array}{l}\text { To what extent do you believe } \\
\text { Bernie Sanders actually said } \\
\text { tuition to public colleges and } \\
\text { universities should be free? }\end{array}$ & $\begin{array}{l}\text { Tuition at public colleges } \\
\text { and universities should be } \\
\text { free for all students. }\end{array}$ & $\begin{array}{l}\text { How important is the issue } \\
\text { of college access to you, } \\
\text { relative to other issues? }\end{array}$ & $\begin{array}{l}\text { To what extent are you } \\
\text { interested in learning more } \\
\text { about proposals for } \\
\text { tuition-free college? }\end{array}$ \\
\hline 1041 & $\begin{array}{l}\text { Undocumented } \\
\text { Children }\end{array}$ & immigration & $\begin{array}{l}\text { To what extent do you believe the } \\
\text { children were actually confused } \\
\text { about immigration court } \\
\text { procedures? }\end{array}$ & $\begin{array}{l}\text { The government should be } \\
\text { required to provide legal } \\
\text { representation to children } \\
\text { who are undocumented. }\end{array}$ & $\begin{array}{l}\text { How important is the issue } \\
\text { of immigration to you, } \\
\text { relative to other issues? }\end{array}$ & $\begin{array}{l}\text { To what extent are you } \\
\text { interested in learning more } \\
\text { about policies related to } \\
\text { immigrant children? }\end{array}$ \\
\hline
\end{tabular}




\begin{tabular}{|c|c|c|c|c|c|c|}
\hline Video ID & Video Title & Topic & Belief Item & Persuasion Item & Importance Item & Engagement Item \\
\hline 1042 & $\begin{array}{l}\text { Vocational } \\
\text { Education }\end{array}$ & $\begin{array}{l}\text { public } \\
\text { education }\end{array}$ & $\begin{array}{l}\text { To what extent do you believe the } \\
\text { speaker actually said there needs } \\
\text { to be more funding for career and } \\
\text { technical education? }\end{array}$ & $\begin{array}{l}\text { The government should } \\
\text { provide more funding for } \\
\text { career and technical } \\
\text { education in public high } \\
\text { schools. }\end{array}$ & $\begin{array}{l}\text { How important is the issue } \\
\text { of career and technical } \\
\text { education to you, relative to } \\
\text { other issues? }\end{array}$ & $\begin{array}{c}\text { To what extent are you } \\
\text { interested in learning more } \\
\text { about career and technical } \\
\text { education? }\end{array}$ \\
\hline 1043 & $\begin{array}{l}\text { Walmart and } \\
\text { Bad } \\
\text { Corporations }\end{array}$ & $\begin{array}{c}\text { corporations' } \\
\text { treatment of } \\
\text { their } \\
\text { employees }\end{array}$ & $\begin{array}{l}\text { To what extent do you believe the } \\
\text { speaker actually said Walmart } \\
\text { does not care about its } \\
\text { employees? }\end{array}$ & $\begin{array}{l}\text { Employers generally pursue } \\
\text { profits at the expense of } \\
\text { their employees. }\end{array}$ & $\begin{array}{l}\text { How important is the issue } \\
\text { of corporations' treatment } \\
\text { of employees to you, relative } \\
\text { to other issues? }\end{array}$ & $\begin{array}{l}\text { To what extent are you } \\
\text { interested in learning more } \\
\text { about corporations' } \\
\text { treatment of their } \\
\text { employees? }\end{array}$ \\
\hline 1045 & We Call B.S. & $\begin{array}{l}\text { gun laws in } \\
\text { the United } \\
\text { States }\end{array}$ & $\begin{array}{l}\text { To what extent do you believe the } \\
\text { speaker actually said politicians } \\
\text { should do more to stop gun } \\
\text { violence? }\end{array}$ & $\begin{array}{l}\text { There should be stricter gun } \\
\text { laws in the United States. }\end{array}$ & $\begin{array}{l}\text { How important is the issue } \\
\text { of gun control to you, } \\
\text { relative to other issues? }\end{array}$ & $\begin{array}{l}\text { To what extent are you } \\
\text { interested in learning more } \\
\text { about gun laws in the } \\
\text { United States? }\end{array}$ \\
\hline 1046 & $\begin{array}{l}\text { We Choose Us } \\
\text { // Amber }\end{array}$ & $\begin{array}{l}\text { grassroots } \\
\text { organizing }\end{array}$ & $\begin{array}{l}\text { To what extent do you believe the } \\
\text { speaker actually said there needs } \\
\text { to be a new generation of political } \\
\text { leaders? }\end{array}$ & $\begin{array}{l}\text { A new generation of leaders } \\
\text { is needed to change the } \\
\text { political system. }\end{array}$ & $\begin{array}{l}\text { How important is the issue } \\
\text { of grassroots organizing to } \\
\text { you, relative to other issues? }\end{array}$ & $\begin{array}{c}\text { To what extent are you } \\
\text { interested in learning more } \\
\text { about grassroots organizing } \\
\text { practices? }\end{array}$ \\
\hline 1047 & $\begin{array}{l}\text { We The } \\
\text { People // } \\
\text { Gaby }\end{array}$ & $\begin{array}{l}\text { income } \\
\text { inequality }\end{array}$ & $\begin{array}{l}\text { To what extent do you believe the } \\
\text { speaker actually said the system } \\
\text { needs to change to address } \\
\text { income inequality? }\end{array}$ & $\begin{array}{l}\text { The government should take } \\
\text { steps to reduce differences } \\
\text { in income between rich and } \\
\text { poor people. }\end{array}$ & $\begin{array}{l}\text { How important is the issue } \\
\text { of income inequality to you, } \\
\text { relative to other issues? }\end{array}$ & $\begin{array}{l}\text { To what extent are you } \\
\text { interested in learning more } \\
\text { about ways to reduce } \\
\text { income differences between } \\
\text { rich and poor people? }\end{array}$ \\
\hline
\end{tabular}

Table S4: Wording of outcome variables in Study 1.

\begin{tabular}{|c|c|c|c|c|c|}
\hline Video ID & Video Title & Topic & Belief Item & Persuasion Item & Engagement Item \\
\hline 1000 & $\begin{array}{l}\text { How To See Germs Spread } \\
\text { Experiment (Coronavirus) }\end{array}$ & $\begin{array}{l}\text { strategies to prevent } \\
\text { the spread of the } \\
\text { coronavirus }\end{array}$ & $\begin{array}{c}\text { To what extent do you believe the } \\
\text { experiment actually showed that } \\
\text { the virus can spread via } \\
\text { handshakes? }\end{array}$ & $\begin{array}{c}\text { The coronavirus can spread easily } \\
\text { via physical contact, such as } \\
\text { handshakes. }\end{array}$ & $\begin{array}{l}\text { To what extent are you interested } \\
\text { in learning more about strategies } \\
\text { to prevent the spread of the } \\
\text { coronavirus? }\end{array}$ \\
\hline 1001 & $\begin{array}{l}\text { How soap kills the } \\
\text { coronavirus }\end{array}$ & $\begin{array}{l}\text { strategies to prevent } \\
\text { the spread of the } \\
\text { coronavirus }\end{array}$ & $\begin{array}{l}\text { To what extent do you believe the } \\
\text { soap actually removed the virus } \\
\text { after } 20 \text { seconds of handwashing? }\end{array}$ & $\begin{array}{l}\text { Handwashing is most effective in } \\
\text { protecting against COVID- } 19 \\
\text { when done for at least } 20 \text { seconds. }\end{array}$ & $\begin{array}{l}\text { To what extent are you interested } \\
\text { in learning more about strategies } \\
\text { for effective handwashing? }\end{array}$ \\
\hline 1002 & $\begin{array}{l}\text { Coronavirus IV: Last Week } \\
\text { Tonight with John Oliver }\end{array}$ & $\begin{array}{l}\text { the federal } \\
\text { government's } \\
\text { response to the } \\
\text { pandemic }\end{array}$ & $\begin{array}{l}\text { To what extent do you believe } \\
\text { Donald Trump actually said that } \\
\text { the Paycheck Protection Program } \\
\text { was well-run? }\end{array}$ & $\begin{array}{l}\text { The federal government has not } \\
\text { provided enough support to small } \\
\text { businesses during the pandemic. }\end{array}$ & $\begin{array}{l}\text { To what extent are you interested } \\
\text { in learning more about support } \\
\text { for small businesses during the } \\
\text { pandemic? }\end{array}$ \\
\hline 1003 & $\begin{array}{l}\text { Coronavirus is not the flu. } \\
\text { It's worse. }\end{array}$ & $\begin{array}{l}\text { differences between } \\
\text { the coronavirus and } \\
\text { the flu }\end{array}$ & $\begin{array}{l}\text { To what extent do you believe } \\
\text { Anthony Fauci actually said that } \\
\text { COVID-19 has a higher mortality } \\
\text { rate than the flu? }\end{array}$ & $\begin{array}{l}\text { COVID-19 is significantly more } \\
\text { dangerous than the flu. }\end{array}$ & $\begin{array}{l}\text { To what extent are you interested } \\
\text { in learning more about } \\
\text { differences between the } \\
\text { coronavirus and the flu? }\end{array}$ \\
\hline 1004 & $\begin{array}{l}\text { Saluting the Heroes of the } \\
\text { Coronavirus Pandumbic| } \\
\text { The Daily Show }\end{array}$ & $\begin{array}{l}\text { U.S. politicians' } \\
\text { response to the } \\
\text { pandemic }\end{array}$ & $\begin{array}{l}\text { To what extent do you believe } \\
\text { Republican leaders actually } \\
\text { claimed in early } 2020 \text { that the } \\
\text { coronavirus was contained? }\end{array}$ & $\begin{array}{c}\text { Republican politicians have } \\
\text { downplayed the risks of } \\
\text { COVID-19. }\end{array}$ & $\begin{array}{l}\text { To what extent are you interested } \\
\text { in learning more about } \\
\text { Republican politicians' responses } \\
\text { to the pandemic? }\end{array}$ \\
\hline 1005 & $\begin{array}{c}\text { Tucker: Big Tech censors } \\
\text { dissent over coronavirus } \\
\text { lockdowns }\end{array}$ & $\begin{array}{l}\text { the role of tech } \\
\text { companies in } \\
\text { addressing the } \\
\text { pandemic }\end{array}$ & $\begin{array}{l}\text { To what extent do you believe } \\
\text { Senator Cory Booker actually said } \\
\text { that he supported the use of } \\
\text { drones to enforce social } \\
\text { distancing orders? }\end{array}$ & $\begin{array}{l}\text { Tech companies should be } \\
\text { allowed to monitor citizens to } \\
\text { make sure they follow public } \\
\text { health guidelines. (Reverse-coded) }\end{array}$ & $\begin{array}{l}\text { To what extent are you interested } \\
\text { in learning more about the use of } \\
\text { technology to track the spread of } \\
\text { the coronavirus? }\end{array}$ \\
\hline 1006 & $\begin{array}{l}\text { Whistleblowers silenced by } \\
\text { China could have stopped } \\
\text { global coronavirus spread } \\
60 \text { Minutes Australia }\end{array}$ & $\begin{array}{l}\text { the Chinese } \\
\text { government's } \\
\text { response to the } \\
\text { pandemic }\end{array}$ & $\begin{array}{l}\text { To what extent do you believe the } \\
\text { speaker actually said that doctors } \\
\text { in China were forced to lie about } \\
\text { the emergence of the coronavirus? }\end{array}$ & $\begin{array}{l}\text { The Chinese government did not } \\
\text { respond quickly enough to } \\
\text { warnings about the emergence of } \\
\text { COVID-19. }\end{array}$ & $\begin{array}{l}\text { To what extent are you interested } \\
\text { in learning more about the } \\
\text { Chinese government's response to } \\
\text { the pandemic? }\end{array}$ \\
\hline 1007 & $\begin{array}{c}\text { Why Coronavirus Is Hitting } \\
\text { the Black Community } \\
\text { Hardest | The Daily Social } \\
\text { Distancing Show }\end{array}$ & $\begin{array}{l}\text { the impact of } \\
\text { COVID-19 on different } \\
\text { groups }\end{array}$ & $\begin{array}{l}\text { To what extent do you believe } \\
\text { Donald Trump actually said that } \\
\text { the Black community has been } \\
\text { more affected by COVID- } 19 \text { than } \\
\text { other groups? }\end{array}$ & $\begin{array}{l}\text { Black Americans have been hit } \\
\text { harder by COVID-19 than other } \\
\text { groups. }\end{array}$ & $\begin{array}{l}\text { To what extent are you interested } \\
\text { in learning more about racial } \\
\text { disparities in COVID-19 cases? }\end{array}$ \\
\hline 1008 & $\begin{array}{l}\text { Trump Declares Testing } \\
\text { 'Overrated,' As Coronavirus } \\
\text { Deaths Continue to Rise }\end{array}$ & $\begin{array}{l}\text { the federal } \\
\text { government's } \\
\text { response to the } \\
\text { pandemic }\end{array}$ & $\begin{array}{l}\text { To what extent do you believe } \\
\text { Donald Trump actually said that } \\
\text { the U.S. would have very few } \\
\text { COVID-19 cases if fewer people } \\
\text { were tested? }\end{array}$ & $\begin{array}{l}\text { If the U.S. administered fewer } \\
\text { COVID-19 tests, there would be } \\
\text { fewer cases. }\end{array}$ & $\begin{array}{l}\text { To what extent are you interested } \\
\text { in learning more about the federal } \\
\text { government's response to the } \\
\text { coronavirus pandemic? }\end{array}$ \\
\hline 1009 & $\begin{array}{l}\text { WHO: Coronavirus - } \\
\text { questions and answers } \\
\text { (Q\&A) }\end{array}$ & $\begin{array}{l}\text { strategies to prevent } \\
\text { the spread of the } \\
\text { coronavirus }\end{array}$ & $\begin{array}{l}\text { To what extent do you believe the } \\
\text { WHO representative actually said } \\
\text { that people should avoid contact } \\
\text { with live animals to protect } \\
\text { themselves against the } \\
\text { coronavirus? }\end{array}$ & $\begin{array}{l}\text { Avoiding contact with live animals } \\
\text { can help prevent the spread of the } \\
\text { coronavirus. }\end{array}$ & $\begin{array}{l}\text { To what extent are you interested } \\
\text { in learning more about World } \\
\text { Health Organization (WHO) } \\
\text { guidance for preventing the } \\
\text { spread of the coronavirus? }\end{array}$ \\
\hline 1011 & $\begin{array}{l}\text { Is This Coronavirus, or Just } \\
\text { Allergies? Symptoms of } \\
\text { COVID-19 }\end{array}$ & testing for COVID-19 & $\begin{array}{c}\text { To what extent do you believe the } \\
\text { video host actually said that up to } \\
30 \% \text { of negative COVID- } 19 \text { tests } \\
\text { may be false negatives? }\end{array}$ & $\begin{array}{l}\text { It is possible to have COVID-19 } \\
\text { even if you receive a negative test. }\end{array}$ & $\begin{array}{l}\text { To what extent are you interested } \\
\text { in learning more about testing for } \\
\text { COVID-19? }\end{array}$ \\
\hline
\end{tabular}




\begin{tabular}{|c|c|c|c|c|c|}
\hline Video ID & Video Title & Topic & Belief Item & Persuasion Item & Engagement Item \\
\hline 1012 & Coronavirus & $\begin{array}{l}\text { strategies to prevent } \\
\text { the spread of the } \\
\text { coronavirus }\end{array}$ & $\begin{array}{l}\text { To what extent do you believe the } \\
\text { speaker actually said that people } \\
\text { should avoid social contact with } \\
\text { people outside their households? }\end{array}$ & $\begin{array}{l}\text { To prevent the spread of } \\
\text { COVID-19, it is essential that } \\
\text { people avoid unnecessary contact } \\
\text { with people outside their } \\
\text { household. }\end{array}$ & $\begin{array}{c}\text { To what extent are you interested } \\
\text { in learning more about strategies } \\
\text { to prevent the spread of the } \\
\text { coronavirus? }\end{array}$ \\
\hline 1013 & $\begin{array}{l}\text { How we must respond to the } \\
\text { coronavirus pandemic | Bill } \\
\text { Gates }\end{array}$ & $\begin{array}{l}\text { how well-prepared the } \\
\text { world was for the } \\
\text { coronavirus pandemic }\end{array}$ & $\begin{array}{l}\text { To what extent do you believe that } \\
\text { Bill Gates actually said that the } \\
\text { world was not ready for the } \\
\text { coronavirus pandemic? }\end{array}$ & $\begin{array}{l}\text { Governments could have done } \\
\text { significantly more to prepare for } \\
\text { the coronavirus pandemic. }\end{array}$ & $\begin{array}{l}\text { To what extent are you interested } \\
\text { in learning more about ways to } \\
\text { prepare for future pandemics? }\end{array}$ \\
\hline 1014 & $\begin{array}{l}\text { Empty middle seats on } \\
\text { planes won't stop the } \\
\text { coronavirus }\end{array}$ & $\begin{array}{l}\text { the science behind the } \\
\text { coronavirus }\end{array}$ & $\begin{array}{l}\text { To what extent do you believe the } \\
\text { simulation actually showed that } \\
\text { the coronavirus can spread across } \\
\text { airplane rows? }\end{array}$ & $\begin{array}{l}\text { The coronavirus can spread easily } \\
\text { on airplanes, even with safety } \\
\text { precautions in place. }\end{array}$ & $\begin{array}{l}\text { To what extent are you interested } \\
\text { in learning more about the spread } \\
\text { of the coronavirus on airplanes? }\end{array}$ \\
\hline 1015 & $\begin{array}{c}\text { What Are the Craziest } \\
\text { Coronavirus Conspiracy } \\
\text { Theories? | The Daily Social } \\
\text { Distancing Show }\end{array}$ & $\begin{array}{l}\text { theories linking } 5 \mathrm{G} \\
\text { and the coronavirus }\end{array}$ & $\begin{array}{l}\text { To what extent do you believe } \\
\text { Trevor Noah actually said that the } \\
5 \mathrm{G} \text { coronavirus conspiracy is } \\
\text { completely ridiculous? }\end{array}$ & $\begin{array}{l}\text { The coronavirus can spread via } \\
5 \mathrm{G} \text { technology. (Reverse-coded) }\end{array}$ & $\begin{array}{l}\text { To what extent are you interested } \\
\text { in learning more about } \\
\text { coronavirus conspiracy theories? }\end{array}$ \\
\hline 1016 & $\begin{array}{l}\text { Dr. Fauci Answers Trevor's } \\
\text { Questions About } \\
\text { Coronavirus | The Daily } \\
\text { Social Distancing Show }\end{array}$ & $\begin{array}{l}\text { differences between } \\
\text { the coronavirus and } \\
\text { the flu }\end{array}$ & $\begin{array}{l}\text { To what extent do you believe that } \\
\text { Anthony Fauci actually said that } \\
\text { COVID-19 has a higher mortality } \\
\text { rate than the flu? }\end{array}$ & $\begin{array}{l}\text { COVID-19 is significantly more } \\
\text { dangerous than the flu. }\end{array}$ & $\begin{array}{c}\text { To what extent are you interested } \\
\text { in learning more about } \\
\text { differences between the } \\
\text { coronavirus and the flu? }\end{array}$ \\
\hline 1018 & $\begin{array}{l}\text { How to Significantly Slow } \\
\text { Coronavirus? \#Masks4All }\end{array}$ & $\begin{array}{l}\text { strategies to prevent } \\
\text { the spread of the } \\
\text { coronavirus }\end{array}$ & $\begin{array}{l}\text { To what extent do you believe the } \\
\text { professor actually said that } \\
\text { population-wide use of masks is } \\
\text { essential to slowing the spread of } \\
\text { the coronavirus? }\end{array}$ & $\begin{array}{l}\text { During the pandemic, everyone } \\
\text { has a responsibility to wear a face } \\
\text { mask to protect public health. }\end{array}$ & $\begin{array}{l}\text { To what extent are you interested } \\
\text { in learning more about the role of } \\
\text { face masks in preventing the } \\
\text { spread of the coronavirus? }\end{array}$ \\
\hline 1019 & $\begin{array}{c}\text { China Is Censoring } \\
\text { Coronavirus Stories. These } \\
\text { Citizens Are Fighting Back. | } \\
\text { NYT News }\end{array}$ & $\begin{array}{l}\text { the Chinese } \\
\text { government's } \\
\text { response to the } \\
\text { pandemic }\end{array}$ & $\begin{array}{l}\text { To what extent do you believe the } \\
\text { activist actually said that it was } \\
\text { important to preserve } \\
\text { information that was being } \\
\text { censored by the Chinese } \\
\text { government? }\end{array}$ & $\begin{array}{l}\text { The Chinese government has } \\
\text { censored information about the } \\
\text { coronavirus pandemic. }\end{array}$ & $\begin{array}{c}\text { To what extent are you interested } \\
\text { in learning more about the } \\
\text { Chinese government's censorship } \\
\text { of information about the } \\
\text { coronavirus? }\end{array}$ \\
\hline 1020 & $\begin{array}{l}\text { What face masks actually do } \\
\text { against coronavirus }\end{array}$ & $\begin{array}{l}\text { strategies to prevent } \\
\text { the spread of the } \\
\text { coronavirus }\end{array}$ & $\begin{array}{l}\text { To what extent do you believe that } \\
\text { the speaker actually said that } \\
\text { mask-wearing is most effective } \\
\text { when combined with social } \\
\text { distancing and handwashing? }\end{array}$ & $\begin{array}{l}\text { Social distancing is not important } \\
\text { if you are wearing a face mask. } \\
\text { (Reverse-coded) }\end{array}$ & $\begin{array}{l}\text { To what extent are you interested } \\
\text { in learning more about the role of } \\
\text { face masks in preventing the } \\
\text { spread of the coronavirus? }\end{array}$ \\
\hline 1021 & $\begin{array}{l}\text { Bill Gates On Coronavirus: } \\
\text { 'It's Going To Be A While } \\
\text { Before Things Go Back To } \\
\text { Normal' | TODAY }\end{array}$ & $\begin{array}{l}\text { the World Health } \\
\text { Organization }\end{array}$ & $\begin{array}{l}\text { To what extent do you believe Bill } \\
\text { Gates actually said that the U.S. } \\
\text { should provide additional support } \\
\text { for the World Health Organization } \\
\text { (WHO)? }\end{array}$ & $\begin{array}{l}\text { The U.S. government should } \\
\text { provide more funding for the } \\
\text { World Health Organization } \\
\text { (WHO). }\end{array}$ & $\begin{array}{l}\text { To what extent are you interested } \\
\text { in learning more about U.S. } \\
\text { support for the World Health } \\
\text { Organization (WHO)? }\end{array}$ \\
\hline 1022 & $\begin{array}{c}\text { The Real Truth about } \\
\text { Coronavirus by Dr. Steven } \\
\text { Gundry }\end{array}$ & $\begin{array}{c}\text { differences between } \\
\text { the coronavirus and } \\
\text { the flu }\end{array}$ & $\begin{array}{l}\text { To what extent do you believe the } \\
\text { speaker actually said that the } \\
\text { coronavirus has a much longer } \\
\text { incubation period than the } \\
\text { seasonal flu? }\end{array}$ & $\begin{array}{l}\text { COVID-19 is significantly more } \\
\text { dangerous than the flu. }\end{array}$ & $\begin{array}{c}\text { To what extent are you interested } \\
\text { in learning more about } \\
\text { differences between the } \\
\text { coronavirus and the flu? }\end{array}$ \\
\hline 1023 & Get the facts on coronavirus & $\begin{array}{l}\text { strategies to prevent } \\
\text { the spread of the } \\
\text { coronavirus }\end{array}$ & $\begin{array}{l}\text { To what extent do you believe the } \\
\text { physician actually said that you } \\
\text { should self-isolate if you have } \\
\text { come into contact with someone } \\
\text { who has COVID-19? }\end{array}$ & $\begin{array}{l}\text { If you have been in contact with } \\
\text { someone who has COVID-19, it is } \\
\text { essential to self-isolate, even if } \\
\text { you do not have symptoms. }\end{array}$ & $\begin{array}{c}\text { To what extent are you interested } \\
\text { in learning more about strategies } \\
\text { to prevent the spread of the } \\
\text { coronavirus? }\end{array}$ \\
\hline
\end{tabular}

Table S5: Wording of outcome variables in Study 2. 


\section{Final Questions}

After completing the experimental portion of the study, respondents were asked several final questions before being debriefed about the purpose of the study.

- Video problems: (If respondents were shown at least one clip during the experimental portion of the study) "During the survey, we showed you at least one video clip. Did you have any problems viewing any of the video clips?"

$(1=$ Yes, $0=$ No $)$

- (If respondents indicated they had technical issues) "Please describe any problems you had with the video clips."

(Open-ended response)

- Random responding: “Did you respond randomly at any point during the study?"

Note: Please be honest! You will get paid regardless of your response.”

$(1=Y e s, 0=N o)$

- Study 1 debrief:

- Video content: "Thank you for taking part in our survey. Before you go, we would like to tell you more about some of the questions on this survey.

Throughout the survey, we asked you to tell us whether you thought certain stories were real - that is, whether you thought the events in a video or transcript actually happened. Our goal in doing so was to learn whether events and claims seem more believable when they are shown on video versus described in text. However, it is important to note that all of the content you were shown was entirely real.

If you have any final questions or comments about our survey, please leave them below or contact us at mit_perl@yahoo.com.”

(Open-ended response)

- Note: Respondents were only shown this debrief if they were assigned to either the video or transcript condition at least once.

- Study 2 debrief:

- Video timing: "Over the course of this study, you may have been shown videos or transcripts that were created in the early stages of the pandemic (i.e., in March 2020 or before). In some cases, public health guidance has changed substantially since these stories were first produced.

As a result, we strongly caution against taking advice from these videos without first consulting the most up-to-date public health recommendations, such as those from the Centers for Disease Control and Prevention (CDC)." 
- Video content: "Thank you for taking part in our survey. Before you go, we would like to tell you more about some of the questions on this survey.

Throughout the survey, we asked you to tell us whether you thought the events in a video or transcript actually happened. Our goal in doing so was to learn whether events and claims seem more believable when they are shown on video versus described in text. However, it is important to note that all of the content you were shown came from real clips found on YouTube.

If you have any final questions or comments about our survey, please leave them below or contact us at mit_perl@yahoo.com.”

(Open-ended response)

- Note: Respondents were only shown this debrief if they were assigned to either the video or transcript condition at least once. 


\section{Model Specification and Diagnostics}

\subsection{Primary Analyses}

In this section, we outline the model specifications used to test our main hypotheses. Following our preregistration, we fit a series of Bayesian multi-level models using the brms package in R. Our primary quantity of interest for each of these models is the average treatment effect of video vs. text for each of our five outcome variables (believability, attitudinal persuasion, sharing intentions, personal importance, and interest in learning more). To estimate the treatment effects of exposure to video and text, we include two dummy variables: the first, video_vs_text, indicates the video treatment (coded 1) relative to the text treatment (0), and the second, control_vs_text, indicates the control group (1) relative to the text treatment $(0)$. This second dummy variable is only included for outcome variables asked of respondents in the control condition.

Each model allows the intercept and the treatment effects to vary across persuasive messages, as well as across respondents. The prior distributions on all parameters are vague and weakly-informative, allowing the data to speak for themselves. The formal specification of the model is presented below, where $Y_{i}$ corresponds to one of the five outcome variables described above, $i$ indexes respondent-message pairs, $J$ indexes the vector of parameters for individual messages, $K$ indexes the vector of parameters for individual respondents, and both $\mathbf{R}_{J}$ and $\mathbf{R}_{K}$ are $3 \times 3$ correlation matrices.

$$
\begin{aligned}
Y_{i} & \sim \operatorname{Normal}\left(\mu_{i}, \sigma\right) \\
\mu_{i} & =\phi+\lambda_{1} \text { video_vs_text }_{i}+\lambda_{2} \text { control_vs_text }_{i} \\
\phi & =\alpha+\alpha_{J[i]}+\alpha_{K[i]} \\
\lambda_{1} & =\beta_{1}+\beta_{1 J[i]}+\beta_{1 K[i]} \\
\lambda_{2} & =\beta_{2}+\beta_{2 J[i]}+\beta_{2 K[i]} \\
{\left[\begin{array}{c}
\alpha_{J} \\
\beta_{1 J} \\
\beta_{2 J}
\end{array}\right] } & \sim \operatorname{MVNormal}\left(\left[\begin{array}{l}
0 \\
0 \\
0
\end{array}\right], \mathbf{S}_{J}\right) \\
{\left[\begin{array}{c}
\alpha_{K} \\
\beta_{1 K} \\
\beta_{2 K}
\end{array}\right] } & \sim \operatorname{MVNormal}\left(\left[\begin{array}{l}
0 \\
0 \\
0
\end{array}\right], \mathbf{S}_{K}\right) \\
\mathbf{S}_{J} & =\left(\begin{array}{ccc}
\sigma_{\alpha_{J}} & 0 & 0 \\
0 & \sigma_{\beta_{1 J}} & 0 \\
0 & 0 & \sigma_{\beta_{2 J}}
\end{array}\right) \mathbf{R}_{J}\left(\begin{array}{ccc}
\sigma_{\alpha_{J}} & 0 & 0 \\
0 & \sigma_{\beta_{1 J}} & 0 \\
0 & 0 & \sigma_{\beta_{2 J}}
\end{array}\right) \\
\mathbf{S}_{K} & =\left(\begin{array}{ccc}
\sigma_{\alpha_{K}} & 0 & 0 \\
0 & \sigma_{\beta_{1 K}} & 0 \\
0 & 0 & \sigma_{\beta_{2 K}}
\end{array}\right) \mathbf{R}_{K}\left(\begin{array}{ccc}
\sigma_{\alpha_{K}} & 0 & 0 \\
0 & \sigma_{\beta_{1 K}} & 0 \\
0 & 0 & \sigma_{\beta_{2 K}}
\end{array}\right)
\end{aligned}
$$




$$
\begin{aligned}
\alpha & \sim \operatorname{Normal}(3,1.5) \\
\beta_{1}, \beta_{2} & \sim \operatorname{Normal}(0,2) \\
\sigma_{\alpha_{J}}, \sigma_{\beta_{1 J}}, \sigma_{\beta_{2 J}} & \sim \operatorname{Exponential}(1) \\
\sigma_{\alpha_{K}}, \sigma_{\beta_{1 K}}, \sigma_{\beta_{2 K}} \sim \operatorname{Exponential}(1) & \\
\sigma & \sim \operatorname{Exponential}(1) \\
\mathbf{R}_{J}, \mathbf{R}_{K} & \sim \operatorname{LKJcorr}(2)
\end{aligned}
$$

Of note, the parameter on the video_vs_text variable is our primary quantity of interest, as this corresponds to the average treatment effect of video versus text for a given outcome. However, in order to determine the directionality of our observed treatment effects, we also benchmark responses against the control group. To do so, we fit the above model twice - once with text as the reference category (as specified) and once with control as the reference category. For the latter case, the second line of the model can be rewritten as follows: $\mu_{i}=\phi+\lambda_{1}$ video_vs_control ${ }_{i}+\lambda_{2}$ text_vs_control ${ }_{i}$. Note that we fit these alternative models only for those outcome measures that were asked of respondents in the control condition.

\subsection{Moderator Models}

In addition to our primary analyses, we also probed the extent to which our estimated treatment effects vary based on both respondent- and message-level characteristics. First, for both Studies 1-2, we examined heterogeneity across several respondent characteristics, including:

1. Age, measured in years.

2. Cognitive reflection, based on the proportion of correct responses to four CRT items.

3. Digital literacy, based on average familiarity with six computer- and Internet-related items.

4. Partisanship, measured using a seven-point scale, where $1=$ strong Democrat and $7=$ strong Republican.

5. Political knowledge, based on the proportion of correct answers to four factual knowledge questions.

In addition, for Study 2, we assessed whether the effect of video versus text varies based on whether the content of the messages was political or non-political, based on crowdsourced ratings from 164 workers on Amazon's Mechanical Turk. Specifically, as discussed in the Materials/Methods section of the main paper, we recoded workers' ratings into a 13-point political score, where $-6=$ extremely confident non-political, $0=$ not sure, and $6=$ extremely confident political. For all of our moderator variables, we fit Bayesian multi-level models in which we linearly interact the treatment indicators (video_vs_text and control_vs_text) with a given moderator variable (age, cognitive reflection, digital literacy, partisanship, 
political knowledge, or political score). All moderator variables are treated as continuous and are standardized, such that they have a mean of 0 and a standard deviation of 1 .

For these analyses, we add three new variables and their corresponding parameters to our primary model specification, described in the previous section. The first new variable, mod, represents the standardized moderator variable, and the latter two, (video_vs_text $\times$ mod) $i$ and (control_vs_text $\times \bmod )_{i}$, represent the linear interactions between the treatment indicators and the moderator variable. As before, the dummy variable control_vs_text is only included for outcome variables asked of respondents in the control condition.

For models measuring moderation by respondent-level characteristics (e.g., partisanship, political knowledge), this interactive model allows all parameters to vary across messages. However, only the intercept and two treatment effects are allowed to vary across respondents. This is because the moderator variables (e.g., partisanship, political knowledge) are measured at the respondent-level and therefore do not vary for a given respondent across messages. The reverse is true for models assessing moderation based on message-specific attributes (e.g., political vs. non-political). The prior distributions on all parameters are again vague and weakly-informative, allowing the data to speak for themselves. The formal specification of the model (based on respondent-level moderators) is as follows, where $Y_{i}$ corresponds to one of our five outcome variables, $i$ indexes respondent-message pairs, $J$ indexes the vector of parameters for individual messages, $K$ indexes the vector of parameters for individual respondents, $\mathbf{R}_{J}$ is a $6 \times 6$ correlation matrix, and $\mathbf{R}_{K}$ is a $3 \times 3$ correlation matrix: $^{1}$

$$
\begin{aligned}
& Y_{i} \sim \operatorname{Normal}\left(\mu_{i}, \sigma\right) \\
& \mu_{i}=\phi+\lambda_{1} \text { video_vs_text }_{i}+\lambda_{2} \text { control_vs_text }_{i}+\lambda_{3} \bmod _{i} \\
& +\lambda_{4}(\text { video_vs_text } \times \text { mod })_{i}+\lambda_{5}(\text { control_vs_text } \times \text { mod })_{i} \\
& \phi=\alpha+\alpha_{J[i]}+\alpha_{K[i]} \\
& \lambda_{1}=\beta_{1}+\beta_{1 J[i]}+\beta_{1 K[i]} \\
& \lambda_{2}=\beta_{2}+\beta_{2 J[i]}+\beta_{2 K[i]} \\
& \lambda_{3}=\beta_{3}+\beta_{3 J[i]} \\
& \lambda_{4}=\beta_{4}+\beta_{4 J[i]} \\
& \lambda_{5}=\beta_{5}+\beta_{5 J[i]} \\
& {\left[\begin{array}{c}
\alpha_{J} \\
\beta_{1 J} \\
\beta_{2 J} \\
\beta_{3 J} \\
\beta_{4 J} \\
\beta_{5 J}
\end{array}\right] \sim \text { MVNormal }\left(\left[\begin{array}{l}
0 \\
0 \\
0 \\
0 \\
0 \\
0
\end{array}\right], \mathbf{S}_{J}\right)} \\
& {\left[\begin{array}{c}
\alpha_{K} \\
\beta_{1 K} \\
\beta_{2 K}
\end{array}\right] \sim \operatorname{MVNormal}\left(\left[\begin{array}{l}
0 \\
0 \\
0
\end{array}\right], \mathbf{s}_{K}\right)}
\end{aligned}
$$

\footnotetext{
${ }^{1}$ The structure of the $J$ and $K$ terms is reversed for models with message-level moderators, such that all the parameters are allowed to vary across respondents but only the intercept, $\lambda_{1}$, and $\lambda_{2}$ are allowed to vary across messages.
} 


$$
\begin{aligned}
& \mathbf{S}_{J}=\left(\begin{array}{cccccc}
\sigma_{\alpha_{J}} & 0 & 0 & 0 & 0 & 0 \\
0 & \sigma_{\beta_{1 J}} & 0 & 0 & 0 & 0 \\
0 & 0 & \sigma_{\beta_{2 J}} & 0 & 0 & 0 \\
0 & 0 & 0 & \sigma_{\beta_{3 J}} & 0 & 0 \\
0 & 0 & 0 & 0 & \sigma_{\beta_{4 J}} & 0 \\
0 & 0 & 0 & 0 & 0 & \sigma_{\beta_{5 J}}
\end{array}\right) \mathbf{R}_{J}\left(\begin{array}{cccccc}
\sigma_{\alpha_{J}} & 0 & 0 & 0 & 0 & 0 \\
0 & \sigma_{\beta_{1 J}} & 0 & 0 & 0 & 0 \\
0 & 0 & \sigma_{\beta_{2 J}} & 0 & 0 & 0 \\
0 & 0 & 0 & \sigma_{\beta_{3 J}} & 0 & 0 \\
0 & 0 & 0 & 0 & \sigma_{\beta_{4 J}} & 0 \\
0 & 0 & 0 & 0 & 0 & \sigma_{\beta_{5 J}}
\end{array}\right) \\
& \mathbf{S}_{K}=\left(\begin{array}{ccc}
\sigma_{\alpha_{K}} & 0 & 0 \\
0 & \sigma_{\beta_{1 K}} & 0 \\
0 & 0 & \sigma_{\beta_{2 K}}
\end{array}\right) \mathbf{R}_{K}\left(\begin{array}{ccc}
\sigma_{\alpha_{K}} & 0 & 0 \\
0 & \sigma_{\beta_{1 K}} & 0 \\
0 & 0 & \sigma_{\beta_{2 K}}
\end{array}\right) \\
& \alpha \sim \operatorname{Normal}(3,1.5) \\
& \beta_{1}, \beta_{2}, \beta_{3}, \beta_{4}, \beta_{5} \sim \operatorname{Normal}(0,2) \\
& \sigma_{\alpha_{J}}, \sigma_{\beta_{1 J}}, \sigma_{\beta_{2 J}}, \sigma_{\beta_{3 J}}, \sigma_{\beta_{4 J}}, \sigma_{\beta_{5 J}} \sim \text { Exponential(1) } \\
& \sigma_{\alpha_{K}}, \sigma_{\beta_{1 K}}, \sigma_{\beta_{2 K}} \sim \operatorname{Exponential}(1) \\
& \sigma \sim \operatorname{Exponential(1)} \\
& \mathbf{R}_{J}, \mathbf{R}_{K} \sim \text { LKJcorr(2). }
\end{aligned}
$$




\subsection{Model Diagnostics: Summary Tables}

In the following section, we report convergence diagnostics for the models whose results are reported in the main text. In particular, for each model, we provide a table containing (i) the parameter estimates, (ii) the effective sample sizes for each parameter (Eff .Sample), and (iii) the $\hat{R}$ values for each parameter $(\hat{\mathrm{R}})$. Note that the reported parameter estimates include the posterior mean (Estimate) and 95\% credible interval (based on the $2.5^{\text {th }}$ and $97.5^{\text {th }}$ percentiles of the posterior distribution, labelled as L.95\% CI and H. 95\% CI, respectively). This approach marks a departure from the main text, which reports the posterior median and 95\% HPDIs, though the two sets of quantities correspond quite closely. In addition to these tables, we also report trace plots for each model parameter. For brevity, we do not include summary tables and trace plots for secondary models whose results are not described in the main text. Instead, these can be found on OSF (https://osf.io/xwmqn/).

\section{Study 1}

Tables S6 through S10 report convergence diagnostics for Study 1. In particular, we provide diagnostics for our primary model specifications, which treat the text condition as the reference category. Each table corresponds to one of our five (standardized) outcome variables: believability, attitudinal persuasion, sharing intentions, interest in learning more, and personal importance. Note that, because respondents in the control condition did not provide ratings of believability and sharing intentions, parameters for the control_vs_text comparison are not available for these outcome measures. For the sake of space, we do not provide a summary of every model parameter (e.g., subject- and message-level random effects).

In all cases, our primary quantities of interest are the fixed effect parameters (denoted within the fixed group) for the video versus text comparison (video_vs_text) and the text versus control comparison (control_vs_text). Parameters within the video_id group correspond to message-level random effects, and parameters within the subject_id group correspond to respondent-level random effects. Of note, because we had relatively few observations per respondent, in several cases the sampling chains for the respondent-level random effects do not appear sufficiently well mixed, especially for the variance parameters (as evidenced by low effective sample sizes and $\hat{R}$ values exceeding 1). However, in Section 5.2, we demonstrate that, in models that omit these respondent-level random effects, we obtain nearly identical treatment effect estimates. 


\begin{tabular}{llcccccc}
\hline Group & Term & Estimate & Est. Error & L. 95\% CI & H. 95\% CI & Eff. Sample & $\hat{\mathbf{R}}$ \\
\hline fixed & Intercept & 3.65 & 0.03 & 3.59 & 3.71 & 3391.18 & 1.00 \\
fixed & video_vs_text & 0.26 & 0.02 & 0.23 & 0.30 & 16000.00 & 1.00 \\
residual & sigma & 0.80 & 0.01 & 0.79 & 0.82 & 1031.93 & 1.00 \\
video_id & sd(Intercept) & 0.18 & 0.02 & 0.14 & 0.23 & 4736.91 & 1.00 \\
video_id & sd(video_vs_text) & 0.05 & 0.03 & 0.00 & 0.11 & 2166.17 & 1.00 \\
video_id & cor(Intercept,video_vs_text) & -0.04 & 0.33 & -0.64 & 0.67 & 16000.00 & 1.00 \\
subject_id & sd(Intercept) & 0.58 & 0.02 & 0.55 & 0.61 & 1688.19 & 1.00 \\
subject_id & sd(video_vs_text) & 0.23 & 0.06 & 0.08 & 0.34 & 287.88 & 1.02 \\
subject_id & cor(Intercept,video_vs_text) & -0.44 & 0.09 & -0.68 & -0.28 & 1070.07 & 1.00 \\
\hline
\end{tabular}

Table S6: Model diagnostics for ratings of believability in Study 1. Reported parameters come from our preregistered model specification (with text as the reference category). The dependent variable is standardized.

\begin{tabular}{llcccccc}
\hline Group & Term & Estimate & Est. Error & L. 95\% CI & H. 95\% CI & Eff. Sample & $\hat{\mathbf{R}}$ \\
\hline fixed & Intercept & 3.19 & 0.04 & 3.12 & 3.26 & 2128.93 & 1.00 \\
fixed & video_vs_text & 0.08 & 0.02 & 0.05 & 0.11 & 16000.00 & 1.00 \\
fixed & control_vs_text & -0.07 & 0.02 & -0.12 & -0.03 & 16000.00 & 1.00 \\
residual & sigma & 0.77 & 0.01 & 0.75 & 0.78 & 1543.72 & 1.00 \\
video_id & sd(Intercept) & 0.23 & 0.03 & 0.18 & 0.29 & 4035.81 & 1.00 \\
video_id & sd(video_vs_text) & 0.03 & 0.02 & 0.00 & 0.07 & 3707.49 & 1.00 \\
video_id & sd(control_vs_text) & 0.08 & 0.03 & 0.02 & 0.13 & 3612.63 & 1.00 \\
video_id & cor(Intercept,video_vs_text) & 0.07 & 0.35 & -0.63 & 0.73 & 16000.00 & 1.00 \\
video_id & cor(Intercept,control_vs_text) & -0.13 & 0.24 & -0.57 & 0.38 & 16000.00 & 1.00 \\
video_id & cor(video_vs_text,control_vs_text) & -0.25 & 0.37 & -0.84 & 0.54 & 3348.35 & 1.00 \\
subject_id & sd(Intercept) & 0.60 & 0.01 & 0.58 & 0.62 & 2647.84 & 1.00 \\
subject_id & sd(video_vs_text) & 0.06 & 0.05 & 0.00 & 0.17 & 498.38 & 1.01 \\
subject_id & sd(control_vs_text) & 0.24 & 0.07 & 0.06 & 0.34 & 403.72 & 1.00 \\
subject_id & cor(Intercept,video_vs_text) & -0.15 & 0.30 & -0.71 & 0.55 & 16000.00 & 1.00 \\
subject_id & cor(Intercept,control_vs_text) & -0.16 & 0.12 & -0.34 & 0.09 & 2368.72 & 1.00 \\
subject_id & cor(video_vs_text,control_vs_text) & 0.04 & 0.40 & -0.73 & 0.75 & 279.55 & 1.01 \\
\hline
\end{tabular}

Table S7: Model diagnostics for ratings of attitudinal persuasion in Study 1. Reported parameters come from our preregistered model specification (with text as the reference category). The dependent variable is standardized.

\begin{tabular}{llcccccc}
\hline Group & Term & Estimate & Est. Error & L. 95\% CI & H. 95\% CI & Eff. Sample & $\hat{\mathbf{R}}$ \\
\hline fixed & Intercept & 1.84 & 0.02 & 1.80 & 1.88 & 2261.31 & 1.00 \\
fixed & video_vs_text & 0.08 & 0.01 & 0.05 & 0.10 & 16000.00 & 1.00 \\
residual & sigma & 0.57 & 0.00 & 0.56 & 0.58 & 16000.00 & 1.00 \\
video_id & sd(Intercept) & 0.08 & 0.01 & 0.06 & 0.11 & 5672.56 & 1.00 \\
video_id & sd(video_vs_text) & 0.02 & 0.02 & 0.00 & 0.06 & 2460.50 & 1.00 \\
video_id & cor(Intercept,video_vs_text) & -0.05 & 0.39 & -0.75 & 0.73 & 12916.97 & 1.00 \\
subject_id & sd(Intercept) & 0.80 & 0.01 & 0.78 & 0.82 & 3392.58 & 1.00 \\
subject_id & sd(video_vs_text) & 0.07 & 0.04 & 0.01 & 0.15 & 381.98 & 1.01 \\
subject_id & cor(Intercept,video_vs_text) & 0.37 & 0.24 & -0.03 & 0.85 & 1048.19 & 1.00 \\
\hline
\end{tabular}

Table S8: Model diagnostics for ratings of sharing intentions in Study 1. Reported parameters come from our preregistered model specification (with text as the reference category). The dependent variable is standardized. 


\begin{tabular}{|c|c|c|c|c|c|c|c|}
\hline Group & Term & Estimate & Est. Error & L. 95\% CI & H. 95\% CI & Eff. Sample & $\hat{\mathbf{R}}$ \\
\hline fixed & Intercept & 2.29 & 0.03 & 2.24 & 2.34 & 3220.59 & 1.00 \\
\hline fixed & video_vs_text & 0.01 & 0.01 & -0.01 & 0.04 & 16000.00 & 1.00 \\
\hline fixed & control_vs_text & -0.05 & 0.02 & -0.08 & -0.01 & 16000.00 & 1.00 \\
\hline residual & sigma & 0.67 & 0.01 & 0.66 & 0.68 & 716.07 & 1.00 \\
\hline video_id & sd(Intercept) & 0.16 & 0.02 & 0.13 & 0.20 & 4974.96 & 1.00 \\
\hline video_id & sd(video_vs_text) & 0.03 & 0.02 & 0.00 & 0.07 & 4098.01 & 1.00 \\
\hline video_id & sd(control_vs_text) & 0.03 & 0.02 & 0.00 & 0.07 & 4987.23 & 1.00 \\
\hline video_id & cor(Intercept,video_vs_text) & 0.20 & 0.34 & -0.54 & 0.79 & 16000.00 & 1.00 \\
\hline video_id & cor(Intercept,control_vs_text) & 0.02 & 0.36 & -0.66 & 0.72 & 16000.00 & 1.00 \\
\hline video_id & cor(video_vs_text,control_vs_text) & 0.02 & 0.40 & -0.74 & 0.76 & 16000.00 & 1.00 \\
\hline subject_id & sd(Intercept) & 0.71 & 0.01 & 0.69 & 0.73 & 4017.79 & 1.00 \\
\hline subject_id & sd(video_vs_text) & 0.17 & 0.05 & 0.07 & 0.26 & 246.53 & 1.02 \\
\hline subject_id & sd(control_vs_text) & 0.29 & 0.05 & 0.17 & 0.38 & 307.06 & 1.01 \\
\hline subject_id & cor(Intercept,video_vs_text) & 0.07 & 0.14 & -0.13 & 0.42 & 365.96 & 1.01 \\
\hline subject_id & cor(Intercept,control_vs_text) & -0.12 & 0.08 & -0.25 & 0.06 & 768.02 & 1.00 \\
\hline subject_id & cor(video_vs_text,control_vs_text) & 0.72 & 0.18 & 0.27 & 0.94 & 330.99 & 1.01 \\
\hline
\end{tabular}

Table S9: Model diagnostics for ratings of interest in learning more in Study 1. Reported parameters come from our preregistered model specification (with text as the reference category). The dependent variable is standardized.

\begin{tabular}{llcccccc}
\hline Group & Term & Estimate & Est. Error & L. 95\% CI & H. 95\% CI & Eff. Sample & $\hat{\mathbf{R}}$ \\
\hline fixed & Intercept & 2.78 & 0.03 & 2.72 & 2.85 & 1372.70 & 1.00 \\
fixed & video_vs_text & 0.04 & 0.02 & 0.01 & 0.07 & 16000.00 & 1.00 \\
fixed & control_vs_text & -0.11 & 0.02 & -0.15 & -0.08 & 16000.00 & 1.00 \\
residual & sigma & 0.77 & 0.01 & 0.76 & 0.79 & 2402.53 & 1.00 \\
video_id & sd(Intercept) & 0.21 & 0.02 & 0.17 & 0.26 & 2812.88 & 1.00 \\
video_id & sd(video_vs_text) & 0.02 & 0.02 & 0.00 & 0.06 & 4182.47 & 1.00 \\
video_id & sd(control_vs_text) & 0.05 & 0.03 & 0.00 & 0.11 & 2739.85 & 1.00 \\
video_id & cor(Intercept,video_vs_text) & 0.15 & 0.37 & -0.61 & 0.78 & 16000.00 & 1.00 \\
video_id & cor(Intercept,control_vs_text) & 0.20 & 0.31 & -0.46 & 0.76 & 16000.00 & 1.00 \\
video_id & cor(video_vs_text,control_vs_text) & -0.01 & 0.40 & -0.74 & 0.73 & 6040.13 & 1.00 \\
subject_id & sd(Intercept) & 0.58 & 0.01 & 0.56 & 0.61 & 5338.84 & 1.00 \\
subject_id & sd(video_vs_text) & 0.07 & 0.04 & 0.00 & 0.17 & 593.79 & 1.00 \\
subject_id & sd(control_vs_text) & 0.10 & 0.07 & 0.00 & 0.24 & 475.13 & 1.01 \\
subject_id & cor(Intercept,video_vs_text) & 0.20 & 0.27 & -0.37 & 0.73 & 4562.67 & 1.00 \\
subject_id & cor(Intercept,control_vs_text) & 0.06 & 0.26 & -0.45 & 0.64 & 3758.99 & 1.00 \\
subject_id & cor(video_vs_text,control_vs_text) & -0.02 & 0.40 & -0.76 & 0.73 & 1404.89 & 1.00 \\
\hline
\end{tabular}

Table S10: Model diagnostics for ratings of personal importance in Study 1. Reported parameters come from our preregistered model specification (with text as the reference category). The dependent variable is standardized. 


\section{Study 2}

Tables S11 through S14 report convergence diagnostics for Study 2. The tables follow the same structure as in the previous section, though respondents in Study 2 were not asked to rate personal importance. The dependent variable in all cases is again standardized. As in Study 1, the sampling chains were not as well mixed for the respondent-level random effects (within the subject_id group). Nevertheless, as we show in Section 5.2, we again obtain nearly identical results when using models that exclude these random effects.

\begin{tabular}{llcccccc}
\hline Group & Term & Estimate & Est. Error & L. 95\% CI & H. 95\% CI & Eff. Sample & $\hat{\mathbf{R}}$ \\
\hline fixed & Intercept & 3.34 & 0.06 & 3.21 & 3.46 & 2246.31 & 1.00 \\
fixed & video_vs_text & 0.28 & 0.02 & 0.23 & 0.32 & 16000.00 & 1.00 \\
residual & sigma & 0.82 & 0.01 & 0.80 & 0.84 & 1311.42 & 1.00 \\
video_id & sd(Intercept) & 0.30 & 0.05 & 0.22 & 0.41 & 4607.29 & 1.00 \\
video_id & sd(video_vs_text) & 0.04 & 0.03 & 0.00 & 0.11 & 5051.50 & 1.00 \\
video_id & cor(Intercept,video_vs_text) & 0.11 & 0.39 & -0.66 & 0.80 & 16000.00 & 1.00 \\
subject_id & sd(Intercept) & 0.51 & 0.02 & 0.47 & 0.56 & 1287.89 & 1.00 \\
subject_id & sd(video_vs_text) & 0.20 & 0.08 & 0.05 & 0.36 & 396.94 & 1.01 \\
subject_id & cor(Intercept,video_vs_text) & -0.54 & 0.14 & -0.83 & -0.27 & 3374.78 & 1.00 \\
\hline
\end{tabular}

Table S1 1: Model diagnostics for ratings of believability in Study 2. Reported parameters come from our preregistered model specification (with text as the reference category). The dependent variable is standardized.

\begin{tabular}{llcccccc}
\hline Group & Term & Estimate & Est. Error & L. 95\% CI & H. 95\% CI & Eff. Sample & $\hat{\mathbf{R}}$ \\
\hline fixed & Intercept & 3.26 & 0.08 & 3.10 & 3.42 & 1267.57 & 1.01 \\
fixed & video_vs_text & 0.11 & 0.02 & 0.07 & 0.16 & 16000.00 & 1.00 \\
fixed & control_vs_text & -0.14 & 0.04 & -0.21 & -0.07 & 11812.30 & 1.00 \\
residual & sigma & 0.83 & 0.01 & 0.81 & 0.85 & 2257.48 & 1.00 \\
video_id & sd(Intercept) & 0.38 & 0.06 & 0.28 & 0.52 & 3447.53 & 1.00 \\
video_id & sd(video_vs_text) & 0.05 & 0.03 & 0.00 & 0.12 & 3973.89 & 1.00 \\
video_id & sd(control_vs_text) & 0.11 & 0.04 & 0.03 & 0.20 & 3517.00 & 1.00 \\
video_id & cor(Intercept,video_vs_text) & -0.00 & 0.34 & -0.64 & 0.66 & 16000.00 & 1.00 \\
video_id & cor(Intercept,control_vs_text) & 0.14 & 0.27 & -0.40 & 0.65 & 13073.27 & 1.00 \\
video_id & cor(video_vs_text,control_vs_text) & 0.00 & 0.38 & -0.72 & 0.70 & 3973.86 & 1.00 \\
subject_id & sd(Intercept) & 0.42 & 0.02 & 0.39 & 0.45 & 4458.22 & 1.00 \\
subject_id & sd(video_vs_text) & 0.06 & 0.05 & 0.00 & 0.19 & 782.85 & 1.01 \\
subject_id & sd(control_vs_text) & 0.17 & 0.10 & 0.01 & 0.36 & 480.85 & 1.01 \\
subject_id & cor(Intercept,video_vs_text) & -0.04 & 0.34 & -0.68 & 0.67 & 8320.77 & 1.00 \\
subject_id & cor(Intercept,control_vs_text) & 0.03 & 0.27 & -0.42 & 0.64 & 1540.48 & 1.00 \\
subject_id & cor(video_vs_text,control_vs_text) & 0.07 & 0.41 & -0.71 & 0.79 & 937.57 & 1.00 \\
\hline
\end{tabular}

Table S12: Model diagnostics for ratings of attitudinal persuasion in Study 2. Reported parameters come from our preregistered model specification (with text as the reference category). The dependent variable is standardized. 


\begin{tabular}{llcccccc}
\hline Group & Term & Estimate & Est. Error & L. 95\% CI & H. 95\% CI & Eff. Sample & $\hat{\mathbf{R}}$ \\
\hline fixed & Intercept & 1.88 & 0.03 & 1.82 & 1.93 & 4791.78 & 1.00 \\
fixed & video_vs_text & 0.08 & 0.02 & 0.03 & 0.12 & 9302.69 & 1.00 \\
residual & sigma & 0.58 & 0.01 & 0.56 & 0.59 & 2107.87 & 1.00 \\
video_id & sd(Intercept) & 0.10 & 0.02 & 0.07 & 0.15 & 8038.72 & 1.00 \\
video_id & sd(video_vs_text) & 0.09 & 0.02 & 0.05 & 0.14 & 7603.24 & 1.00 \\
video_id & cor(Intercept,video_vs_text) & 0.57 & 0.24 & 0.03 & 0.93 & 7789.42 & 1.00 \\
subject_id & sd(Intercept) & 0.80 & 0.01 & 0.77 & 0.83 & 5335.53 & 1.00 \\
subject_id & sd(video_vs_text) & 0.06 & 0.05 & 0.00 & 0.19 & 294.89 & 1.01 \\
subject_id & cor(Intercept,video_vs_text) & -0.03 & 0.32 & -0.70 & 0.68 & 16000.00 & 1.00 \\
\hline
\end{tabular}

Table S13: Model diagnostics for ratings of sharing intentions in Study 2. Reported parameters come from our preregistered model specification (with text as the reference category). The dependent variable is standardized.

\begin{tabular}{llcccccc}
\hline Group & Term & Estimate & Est. Error & L. 95\% CI & H. 95\% CI & Eff. Sample & $\hat{\mathbf{R}}$ \\
\hline fixed & Intercept & 2.17 & 0.04 & 2.09 & 2.25 & 1945.90 & 1.00 \\
fixed & video_vs_text & 0.01 & 0.02 & -0.03 & 0.05 & 16000.00 & 1.00 \\
fixed & control_vs_text & -0.01 & 0.02 & -0.06 & 0.04 & 16000.00 & 1.00 \\
residual & sigma & 0.64 & 0.01 & 0.63 & 0.65 & 503.39 & 1.01 \\
video_id & sd(Intercept) & 0.17 & 0.03 & 0.12 & 0.24 & 5103.26 & 1.00 \\
video_id & sd(video_vs_text) & 0.05 & 0.03 & 0.00 & 0.10 & 3499.78 & 1.00 \\
video_id & sd(control_vs_text) & 0.05 & 0.03 & 0.00 & 0.12 & 3951.04 & 1.00 \\
video_id & cor(Intercept,video_vs_text) & 0.10 & 0.33 & -0.56 & 0.70 & 16000.00 & 1.00 \\
video_id & cor(Intercept,control_vs_text) & -0.17 & 0.34 & -0.76 & 0.56 & 16000.00 & 1.00 \\
video_id & cor(video_vs_text,control_vs_text) & -0.15 & 0.39 & -0.81 & 0.64 & 8254.82 & 1.00 \\
subject_id & sd(Intercept) & 0.75 & 0.01 & 0.72 & 0.77 & 4742.70 & 1.00 \\
subject_id & sd(video_vs_text) & 0.10 & 0.07 & 0.00 & 0.24 & 157.66 & 1.02 \\
subject_id & sd(control_vs_text) & 0.11 & 0.08 & 0.00 & 0.28 & 285.87 & 1.01 \\
subject_id & cor(Intercept,video_vs_text) & -0.03 & 0.26 & -0.55 & 0.56 & 6014.83 & 1.00 \\
subject_id & cor(Intercept,control_vs_text) & -0.04 & 0.26 & -0.55 & 0.56 & 7823.42 & 1.00 \\
subject_id & cor(video_vs_text,control_vs_text) & 0.13 & 0.42 & -0.71 & 0.81 & 780.87 & 1.01 \\
\hline
\end{tabular}

Table S14: Model diagnostics for ratings of interest in learning more in Study 2. Reported parameters come from our preregistered model specification (with text as the reference category). The dependent variable is standardized. 


\subsection{Model Diagnostics: Trace Plots}

In the following section, we produce trace plots for the key parameters from our main model specifications, as reported in the summary tables above. Figures S2 through S6 contain the trace plots for Study 1, and Figures S7 through S10 contain the trace plots for Study 2. As noted above, these plots indicate that the sampling chains for the respondent-level random effects (denoted as subject_id) are less well-mixed than for other parameters, particularly for the variance parameters (denoted as sd).

\section{Study 1}
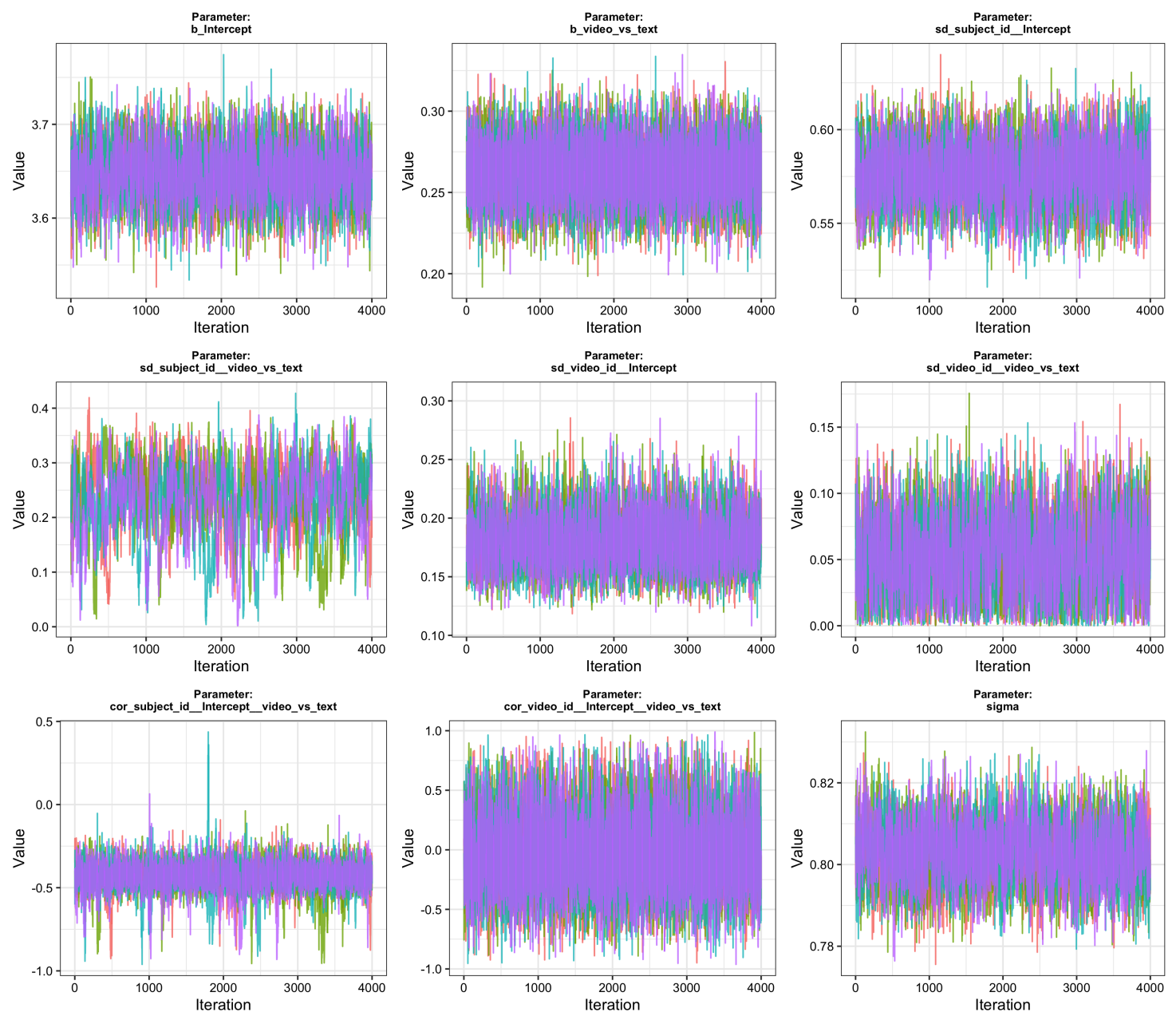

Figure S2: Trace plots for the believability outcome, Study 1. 

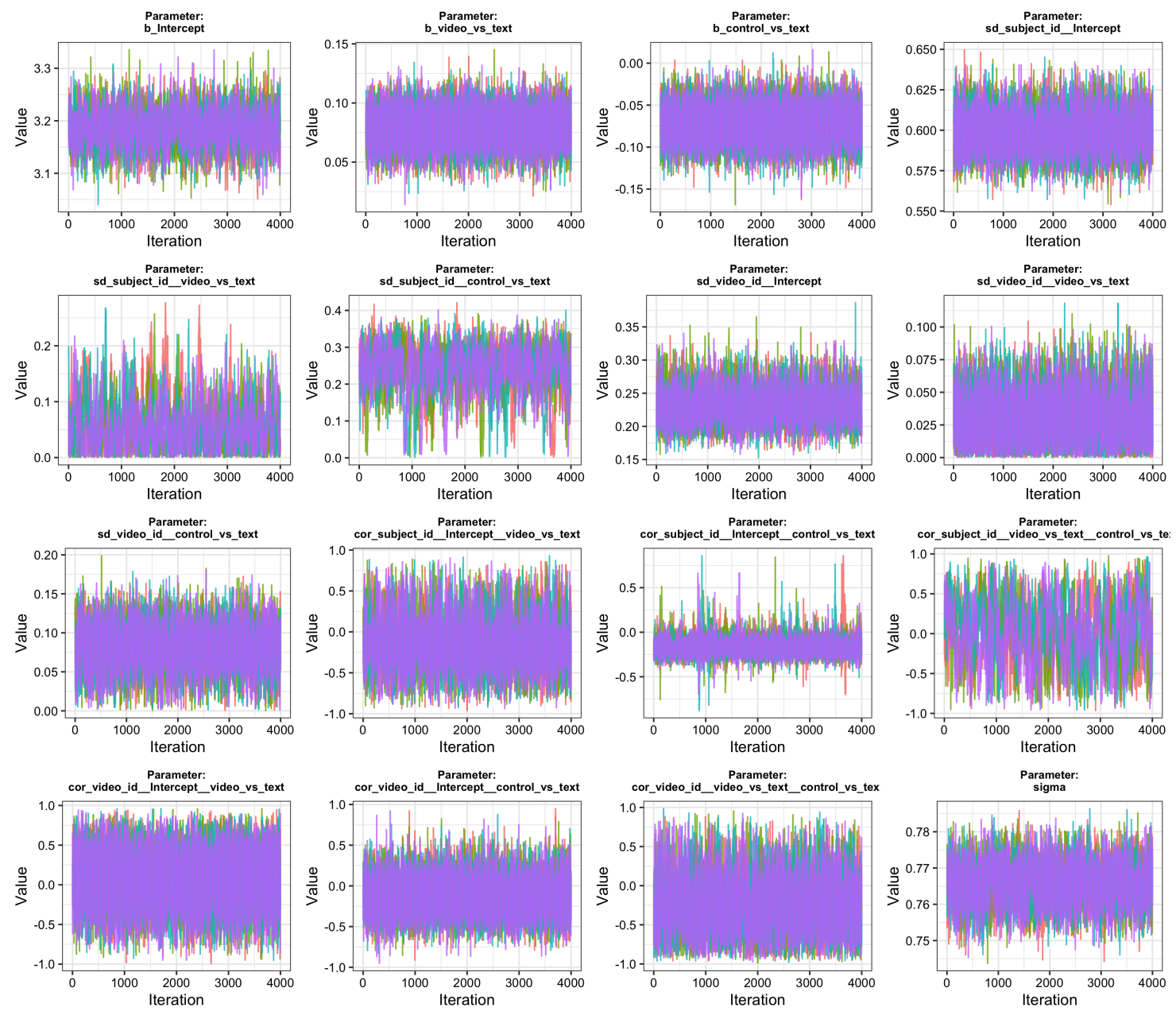

Figure S3: Trace plots for the attitudinal persuasion outcome, Study 1. 

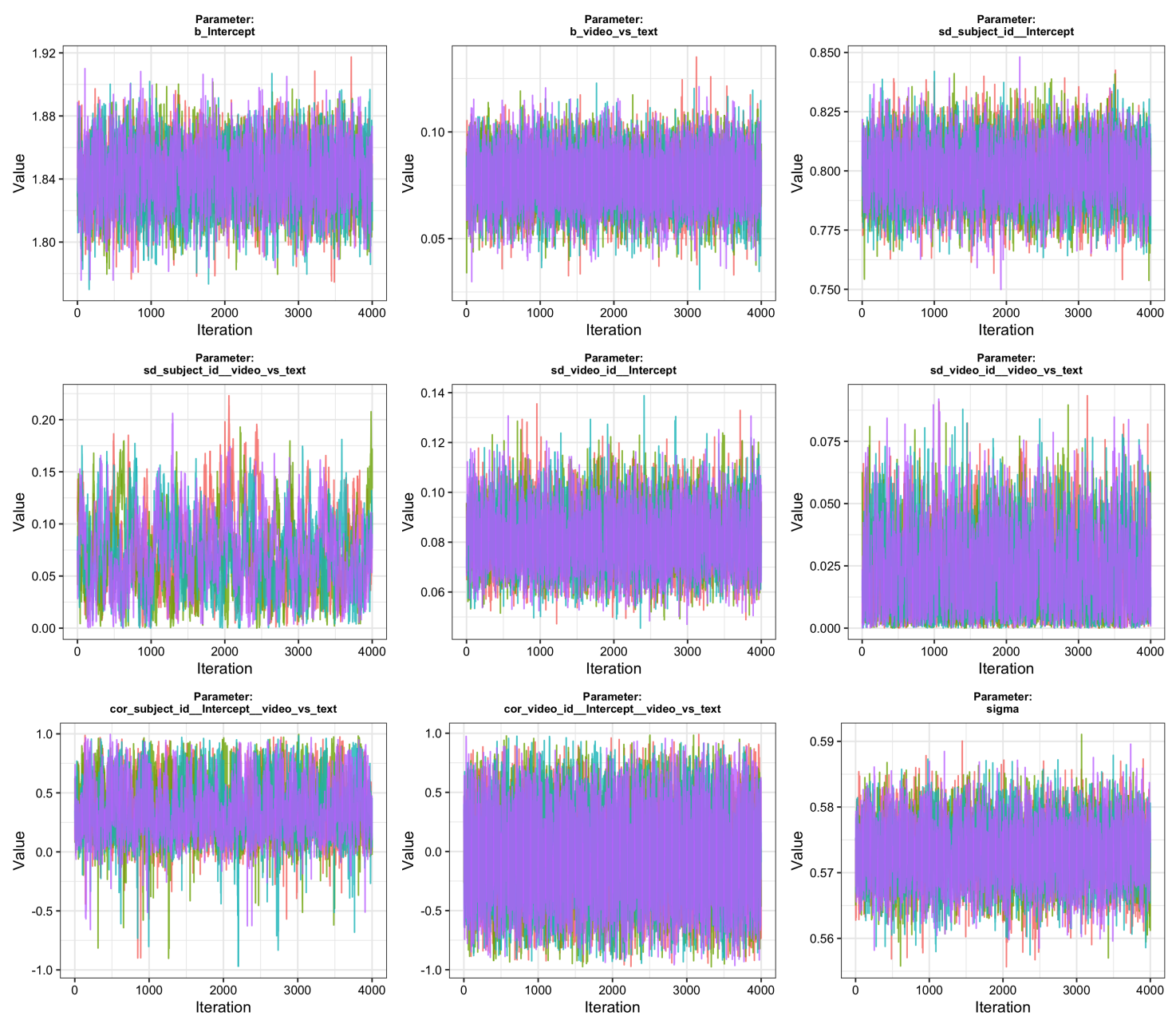

Figure S4: Trace plots for the sharing intentions outcome, Study 1. 

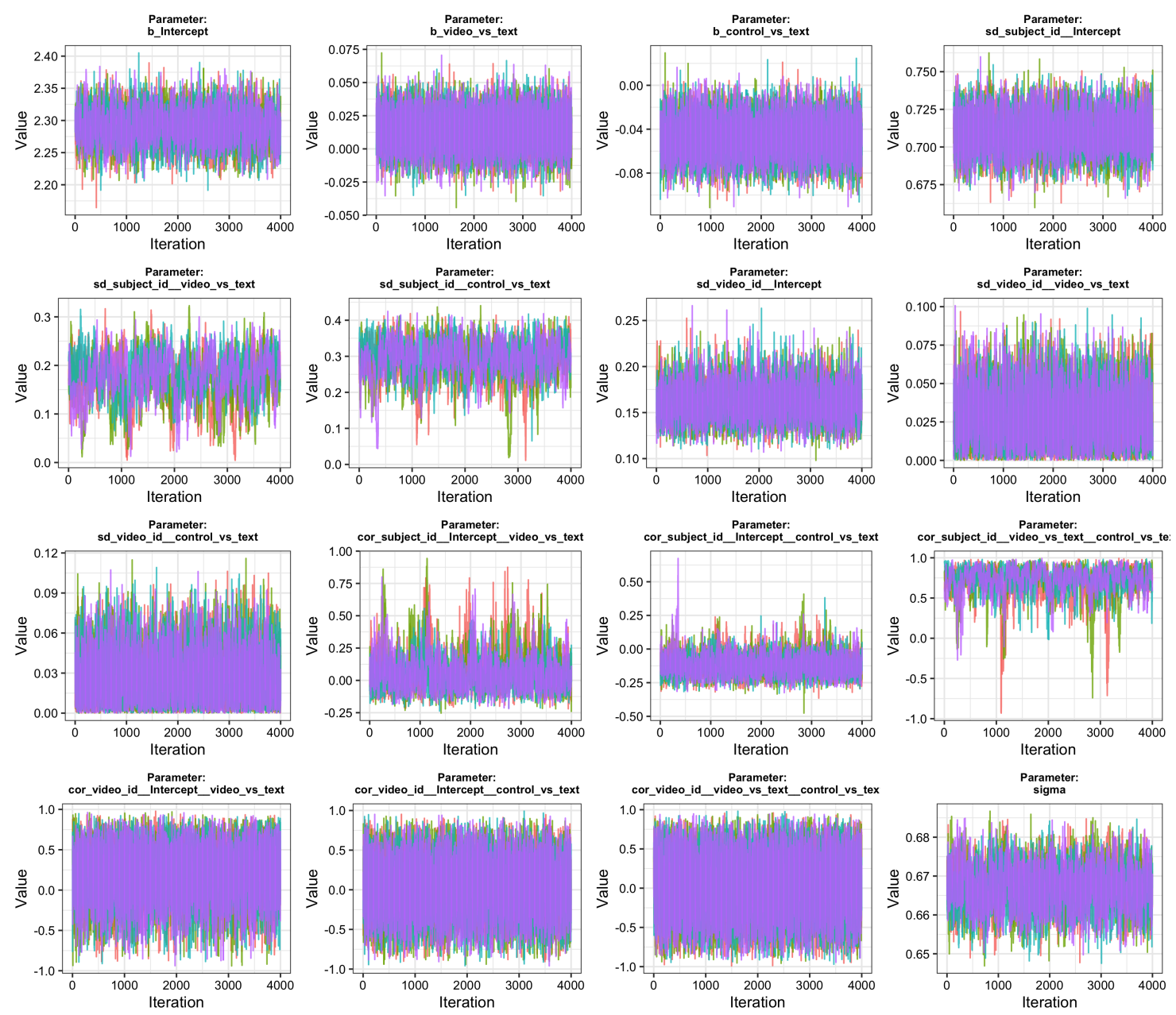

Figure S5: Trace plots for the interest in learning more outcome, Study 1. 

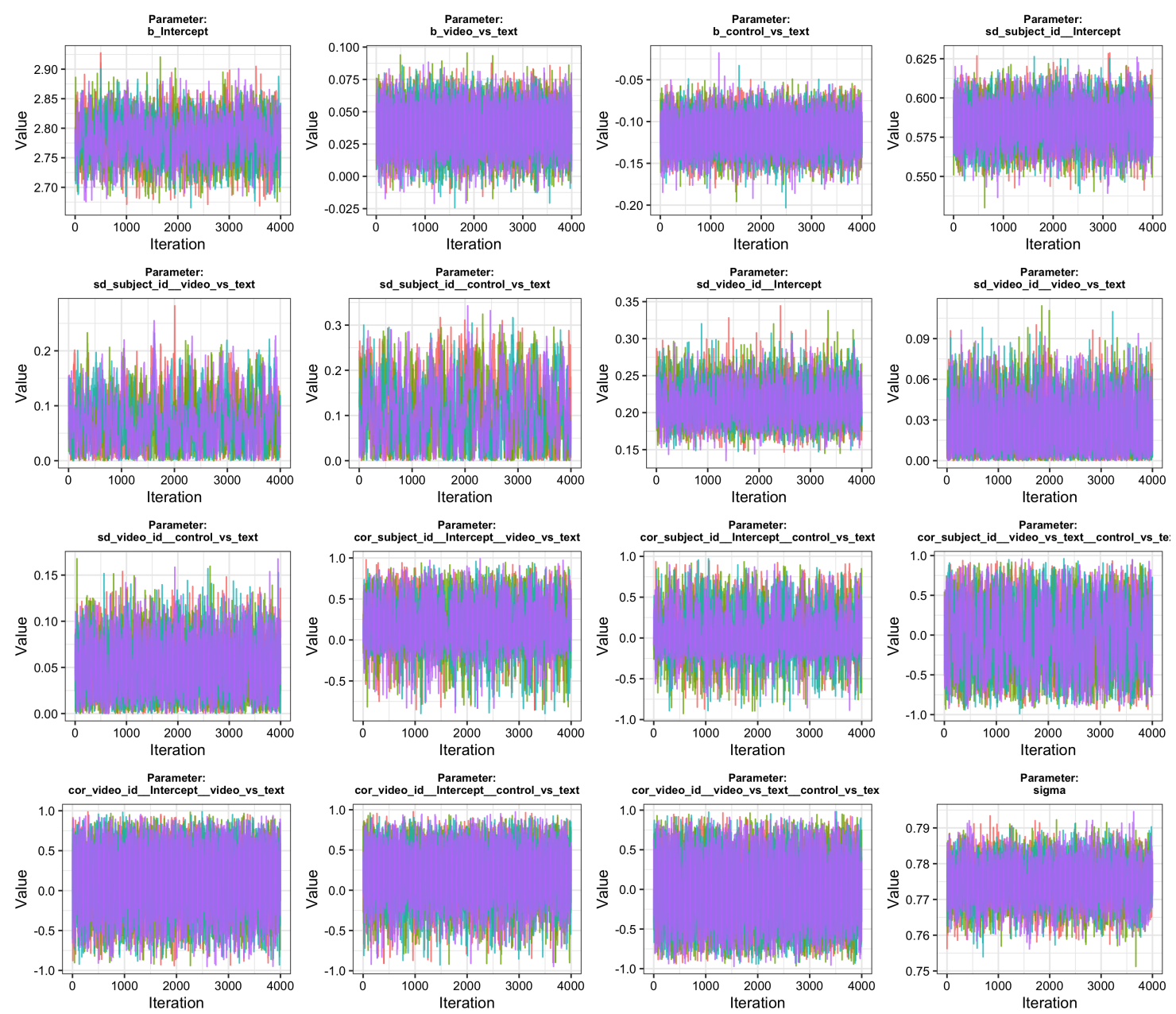

Figure S6: Trace plots for the personal importance outcome, Study 1. 


\section{Study 2}
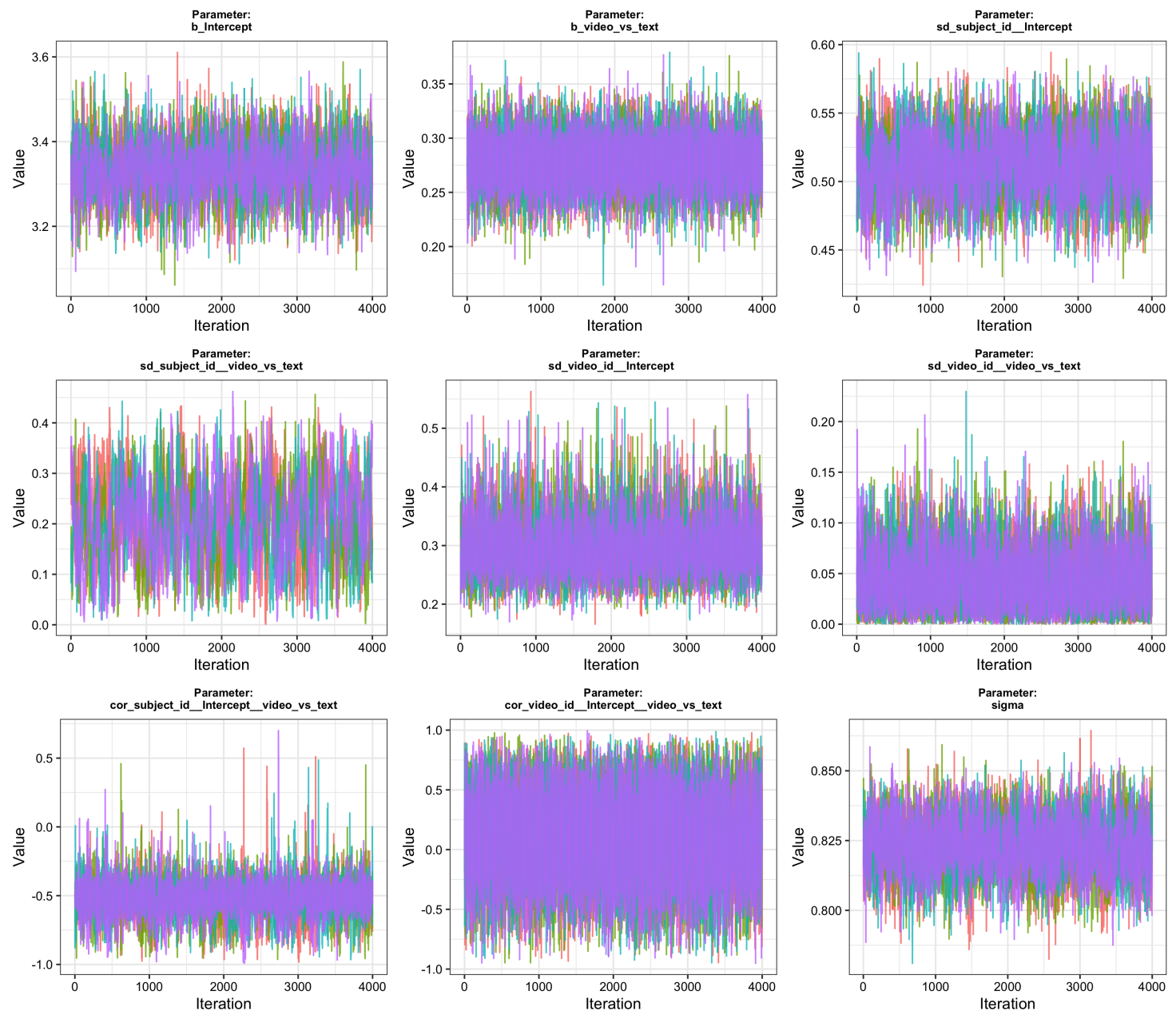

Figure S7: Trace plots for the believability outcome, Study 2. 

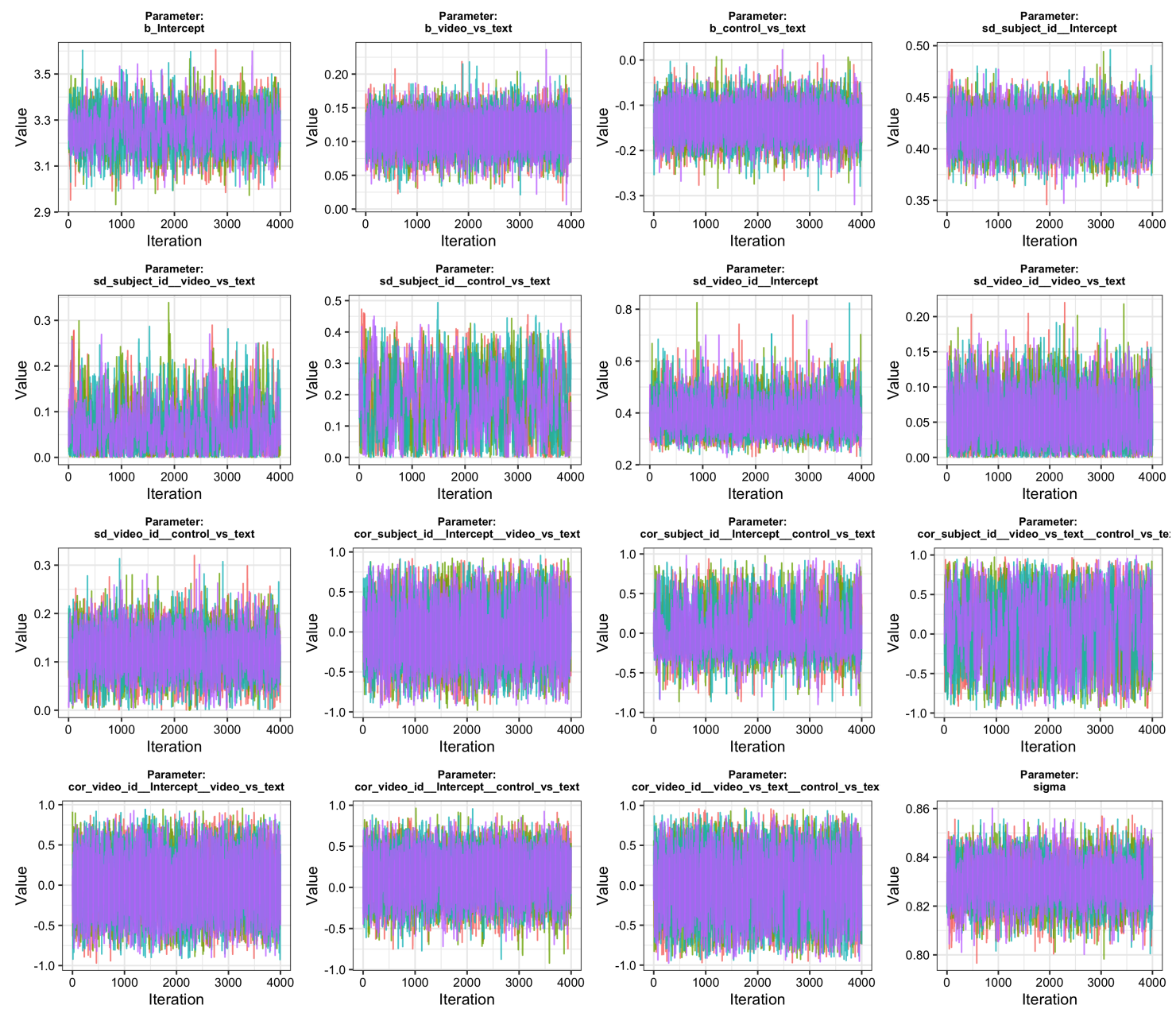

Figure S8: Trace plots for the attitudinal persuasion outcome, Study 2. 

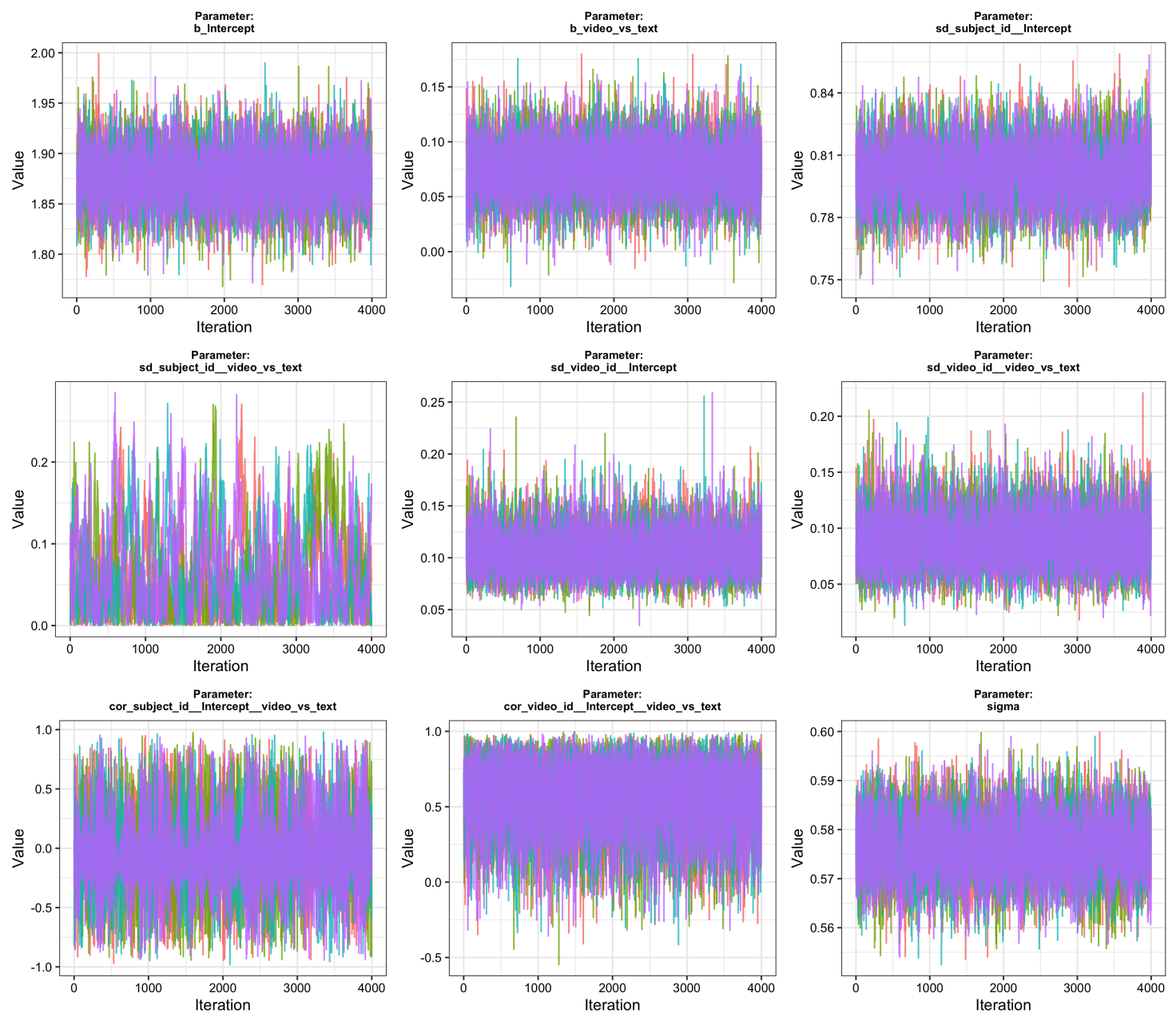

Figure S9: Trace plots for the sharing intentions outcome, Study 2. 

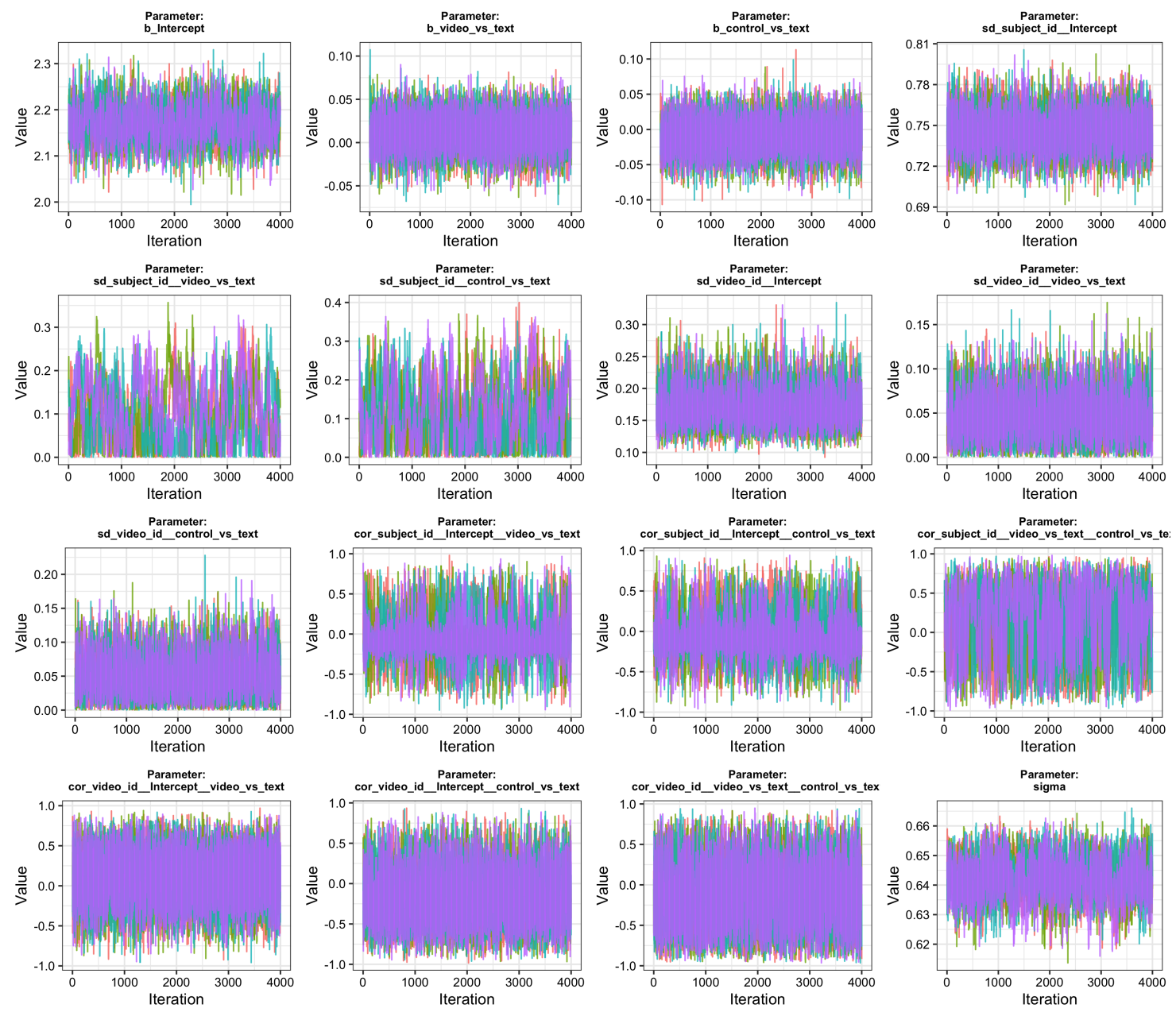

Figure S10: Trace plots for the interest in learning more outcome, Study 2. 


\section{Data Description}

In this section, we display average ratings, disaggregated by persuasive message and experimental condition, for each study. Figures S11 through S15 show average ratings for Study 1, and Figures S16 through S19 show average ratings for Study 2. Ratings of believability and sharing intentions are not available for respondents in the control condition, who were not asked these items. In addition, ratings of personal importance are only available for Study 1. 95\% confidence intervals are displayed in all cases.

\subsection{Study 1}

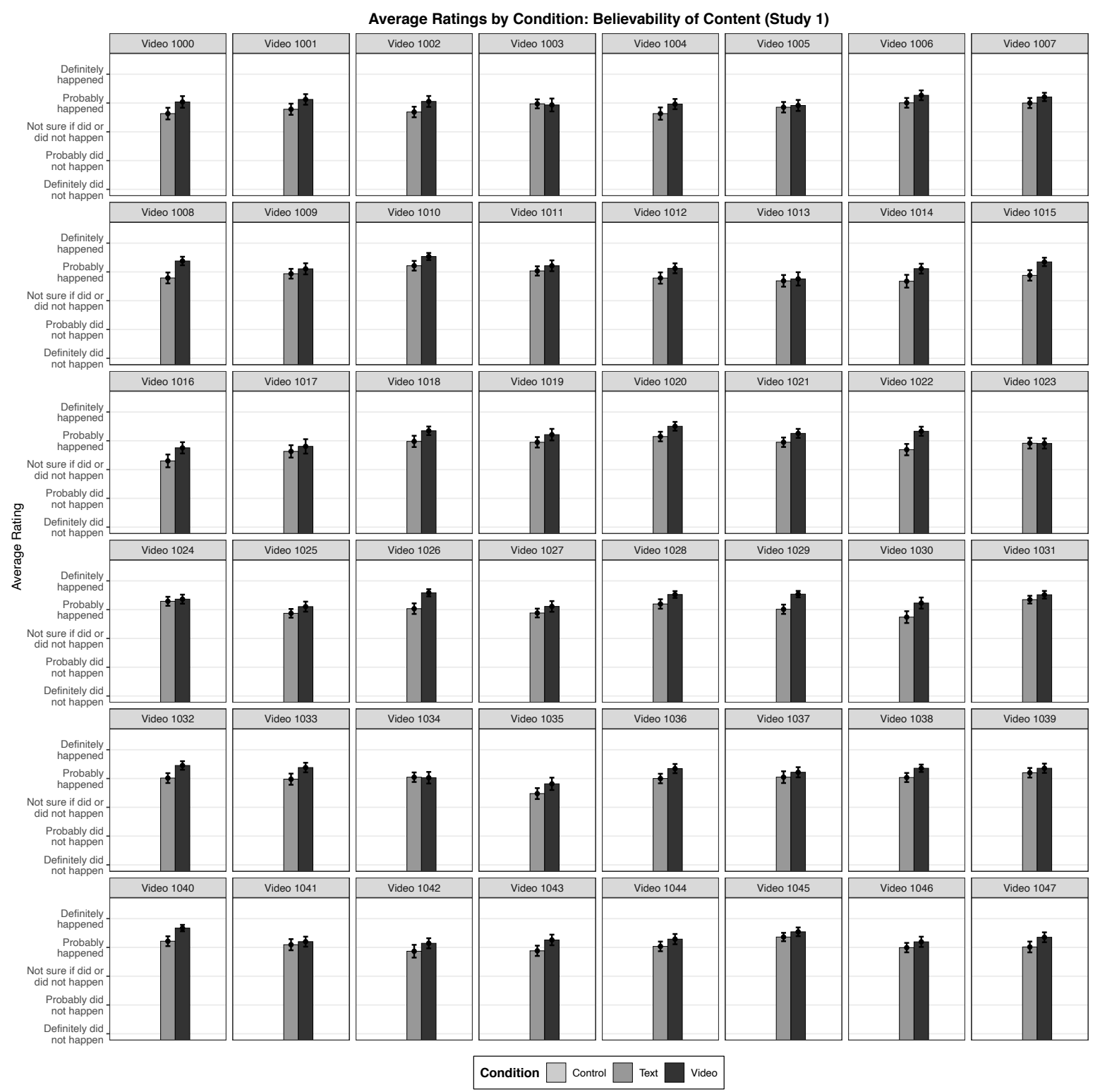

Figure S1 1: Average ratings of believability, disaggregated by experimental condition, for Study 1. 95\% confidence intervals are displayed. 


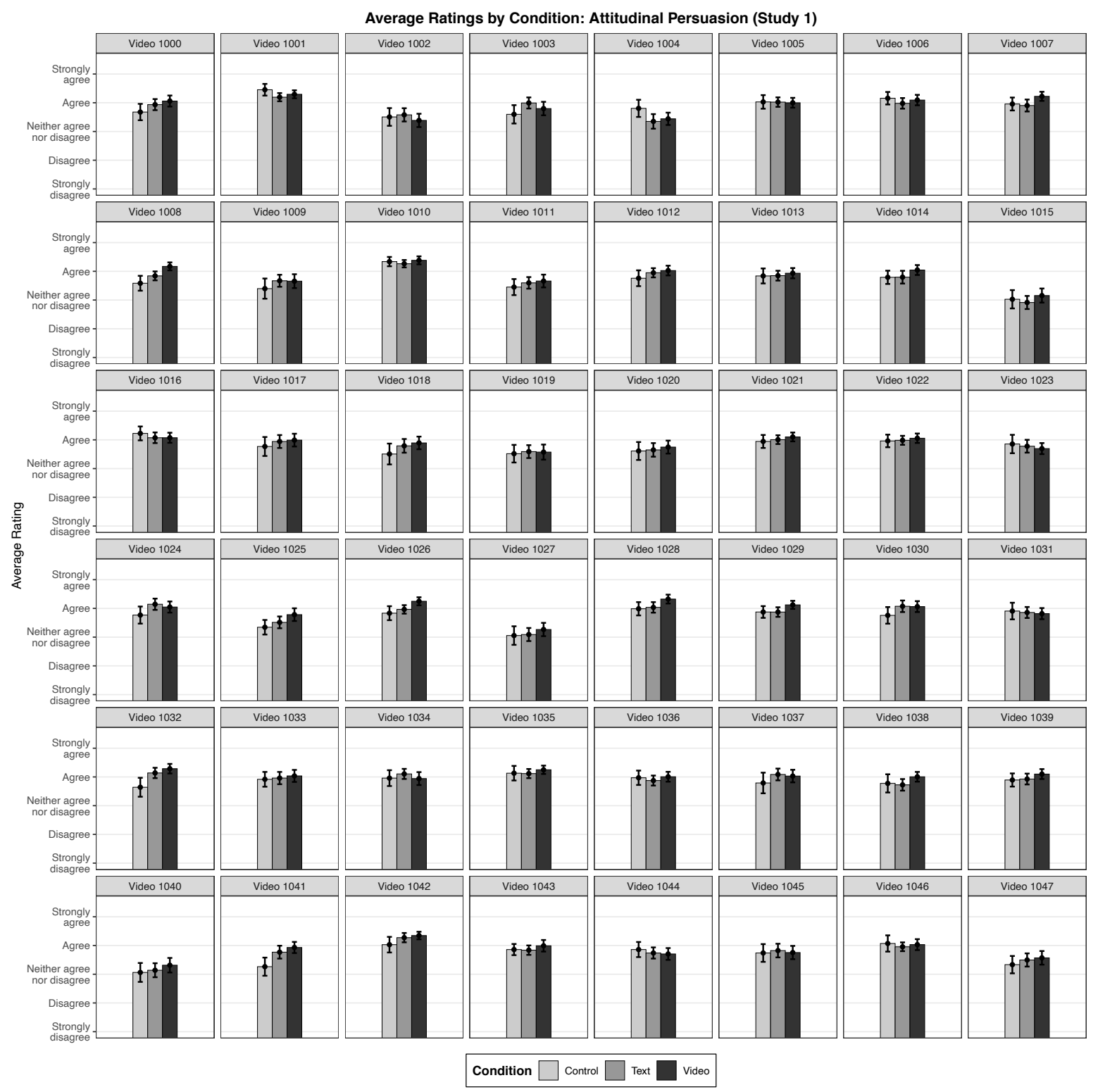

Figure S12: Average ratings of attitudinal persuasion, disaggregated by experimental condition, for Study 1. 95\% confidence intervals are displayed. 


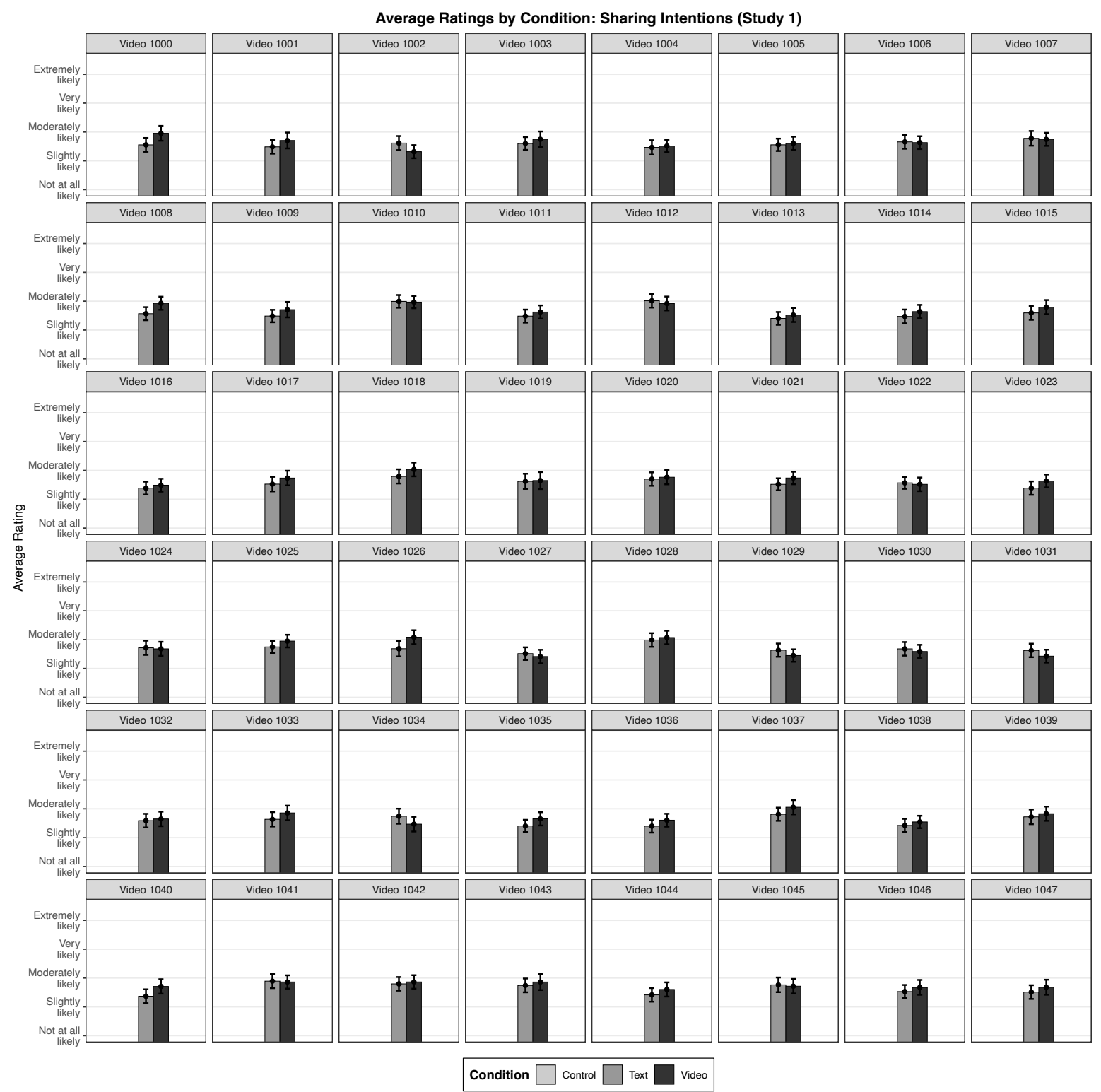

Figure S13: Average ratings of sharing intentions, disaggregated by experimental condition, for Study 1. $95 \%$ confidence intervals are displayed. 


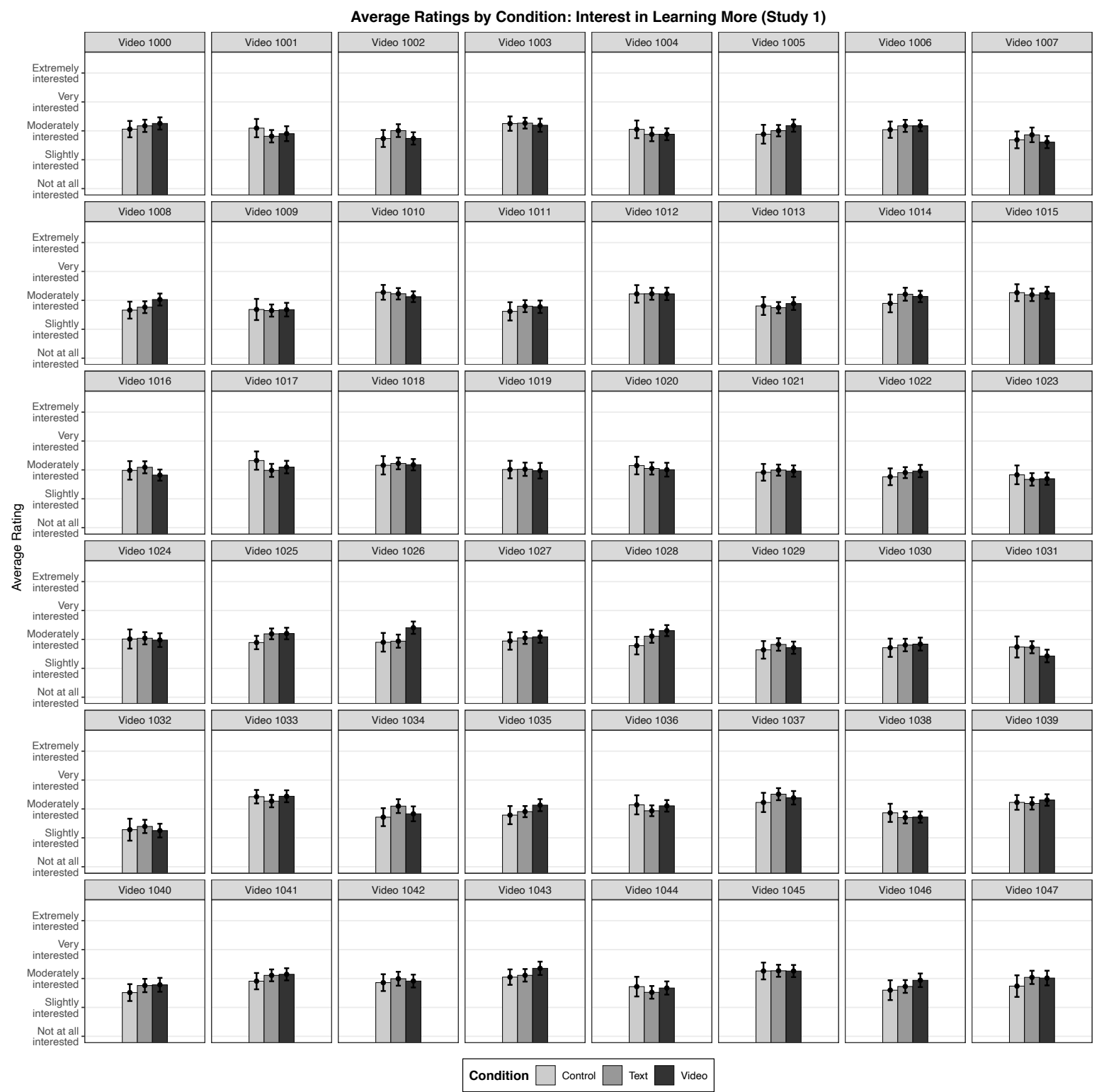

Figure S14: Average ratings of interest in learning more, disaggregated by experimental condition, for Study $1.95 \%$ confidence intervals are displayed. 


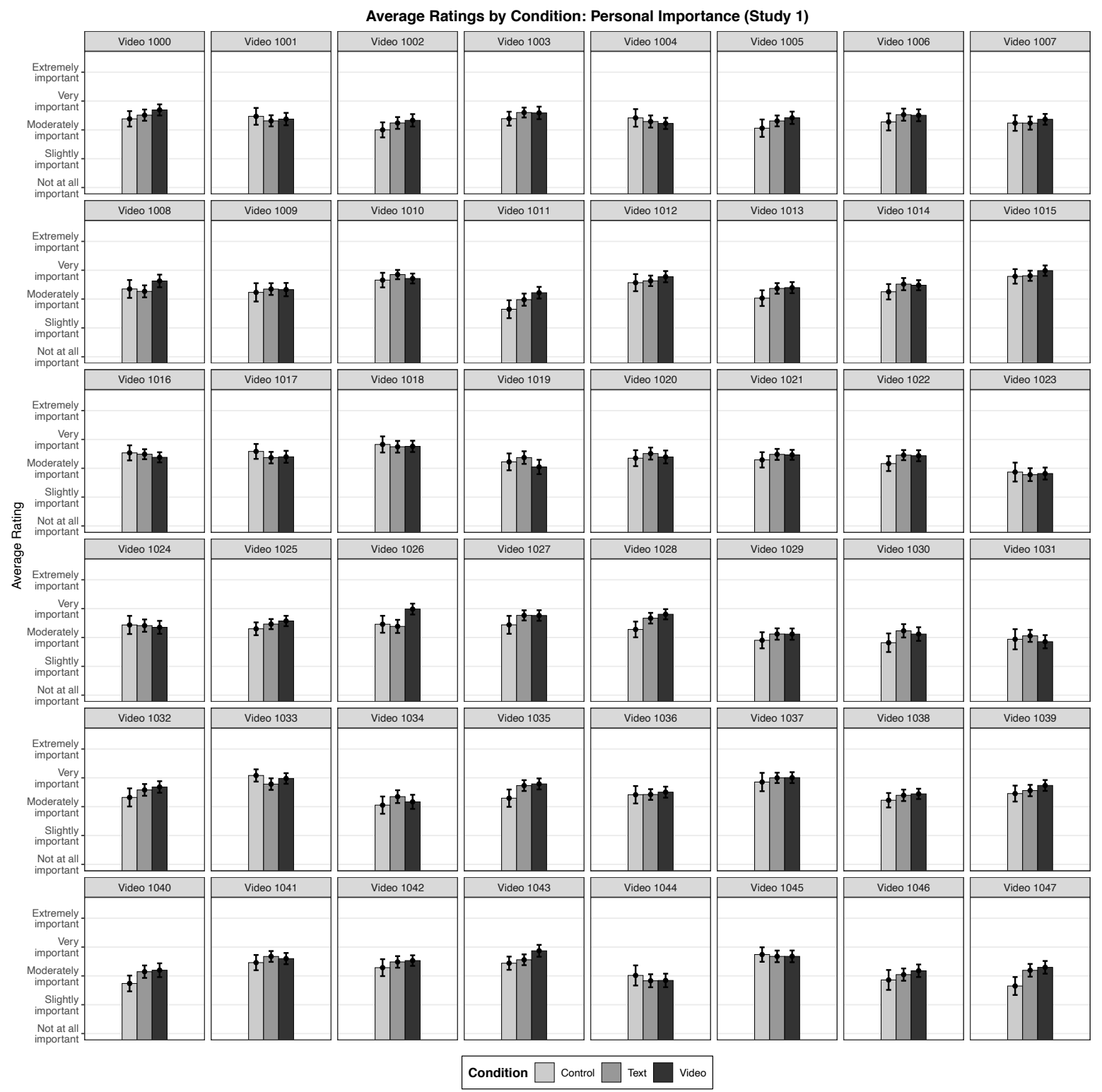

Figure S15: Average ratings of personal importance, disaggregated by experimental condition, for Study 1. 95\% confidence intervals are displayed. 


\subsection{Study 2}

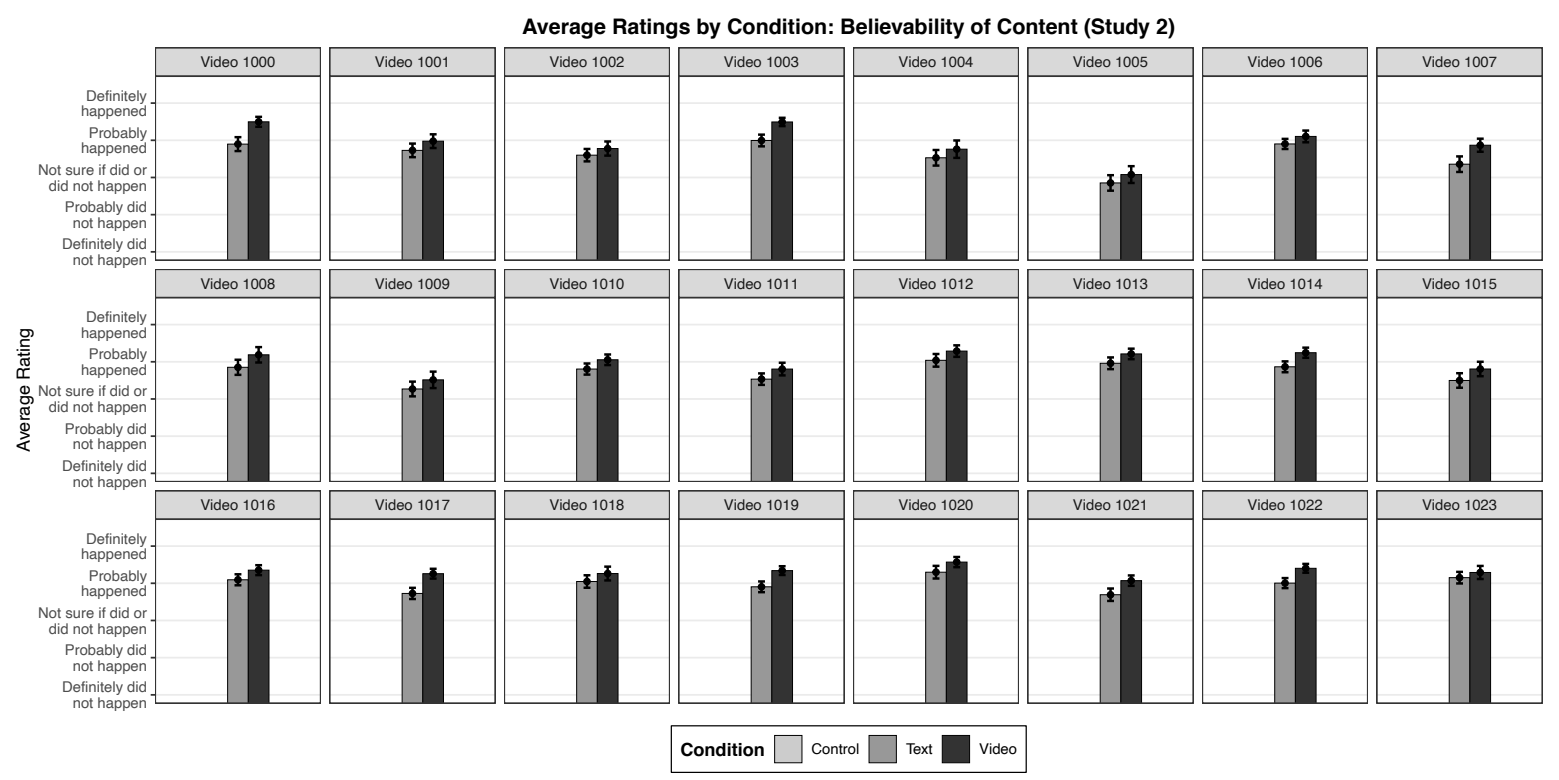

Figure S16: Average ratings of believability, disaggregated by experimental condition, for Study 2. 95\% confidence intervals are displayed.

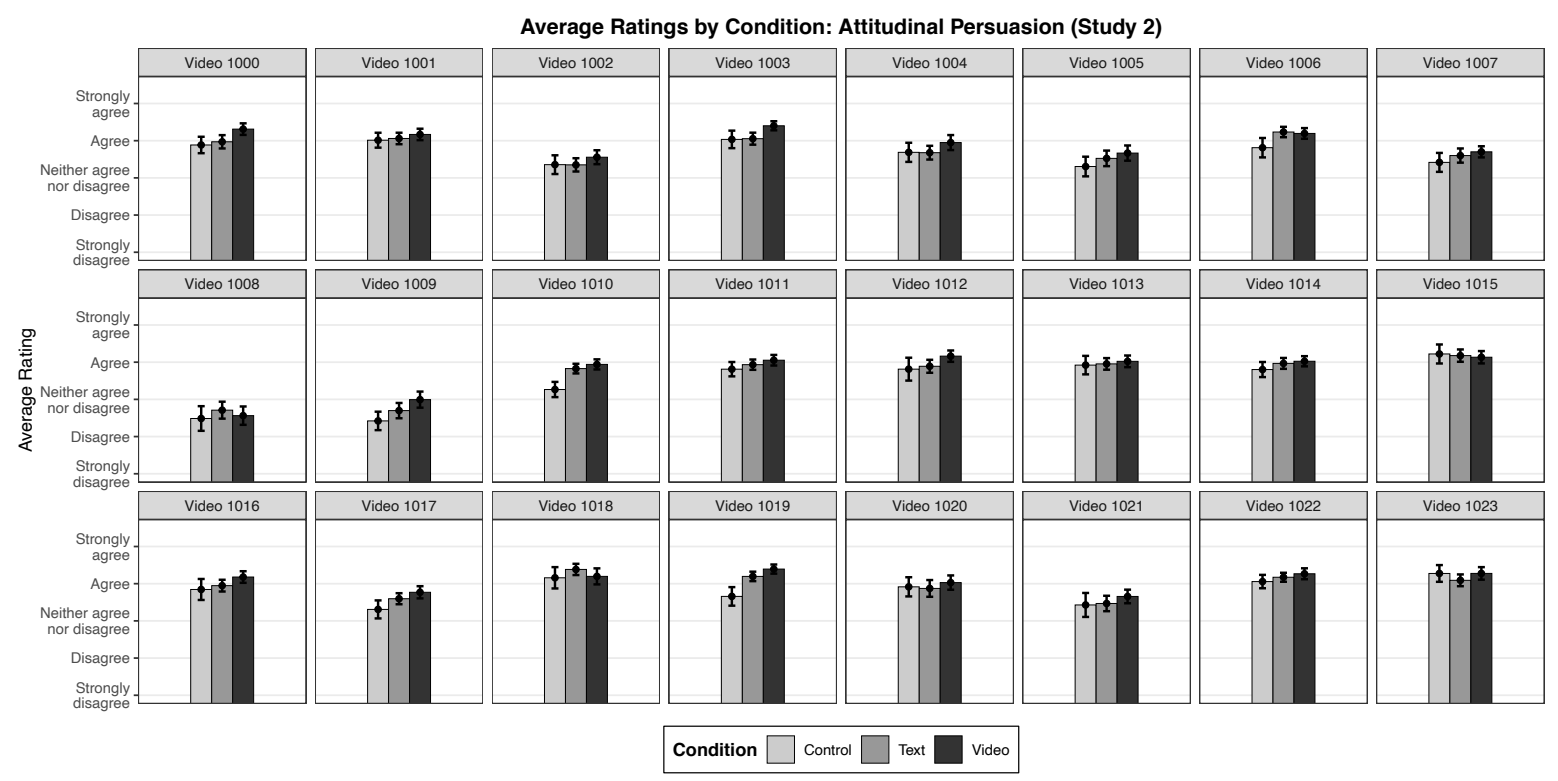

Figure S17: Average ratings of attitudinal persuasion, disaggregated by experimental condition, for Study 2. $95 \%$ confidence intervals are displayed. 


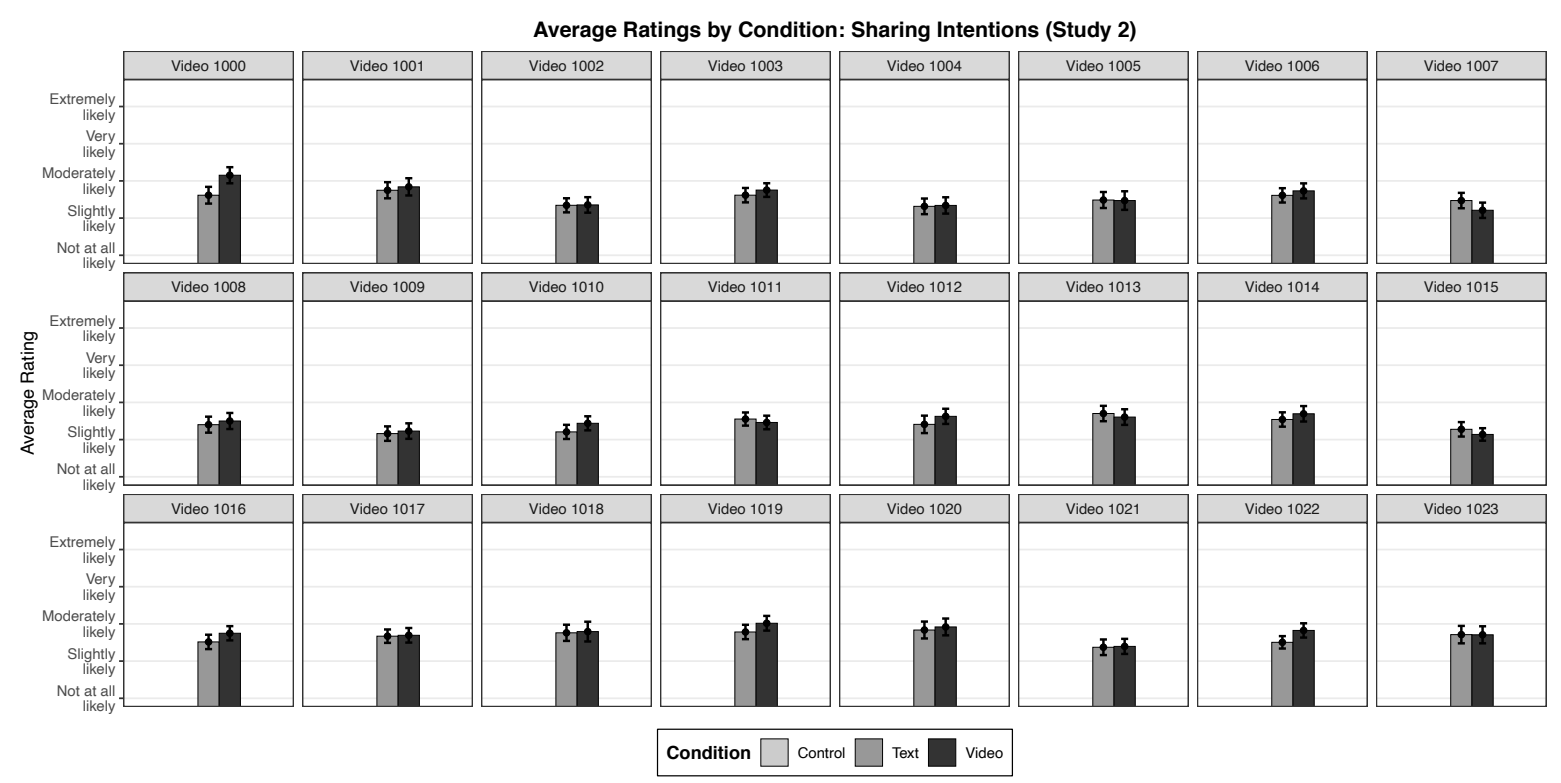

Figure S18: Average ratings of sharing intentions, disaggregated by experimental condition, for Study 2. 95\% confidence intervals are displayed.

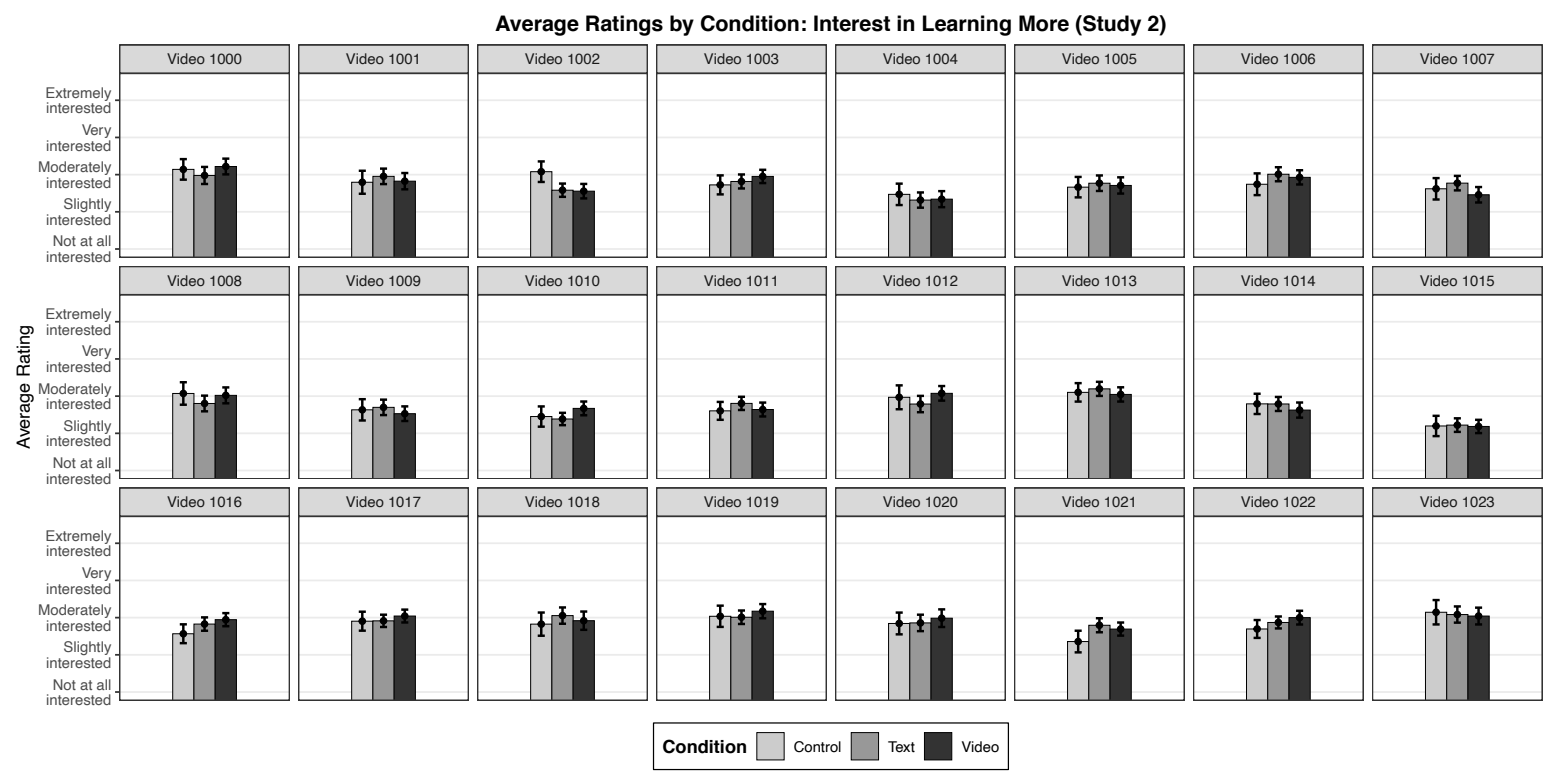

Figure S19: Average ratings of interest in learning more, disaggregated by experimental condition, for Study 2. 95\% confidence intervals are displayed. 


\section{Preregistered Analyses}

\subsection{Comparison to Control Condition}

Figures S20 and S21 plot the standardized treatment effects of assignment to each of the treatment groups, relative to the control condition. Of note, respondents in the control condition were not asked to provide ratings of believability and sharing intentions. In addition, ratings of personal importance are only available for Study 1. The treatment effects in all cases are expressed in terms of standard deviations of the outcome scale.

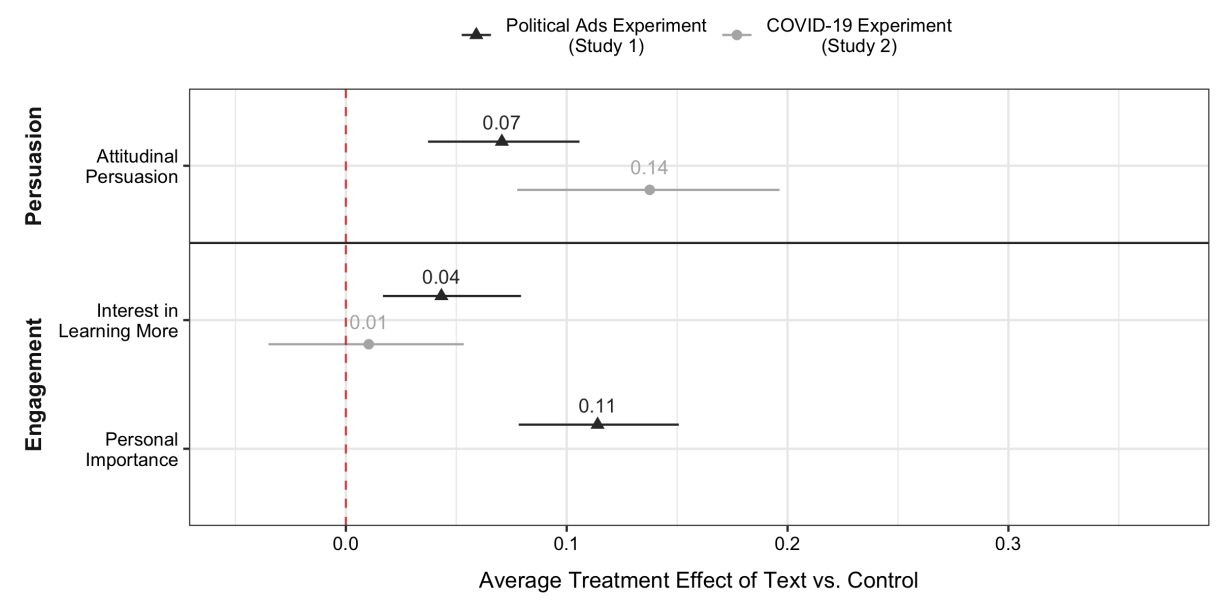

Figure S20: Average treatment effect (ATE) of assignment to the text versus control condition on ratings of persuasion and personal engagement. All estimates are expressed in terms of standard deviations. The point estimate of the ATE is based on the posterior median; specifically, we compute the median of the posterior distribution on the fixed effect parameter for the dummy variable indicating assignment to the text versus control condition. 95\% HPDIs are displayed.

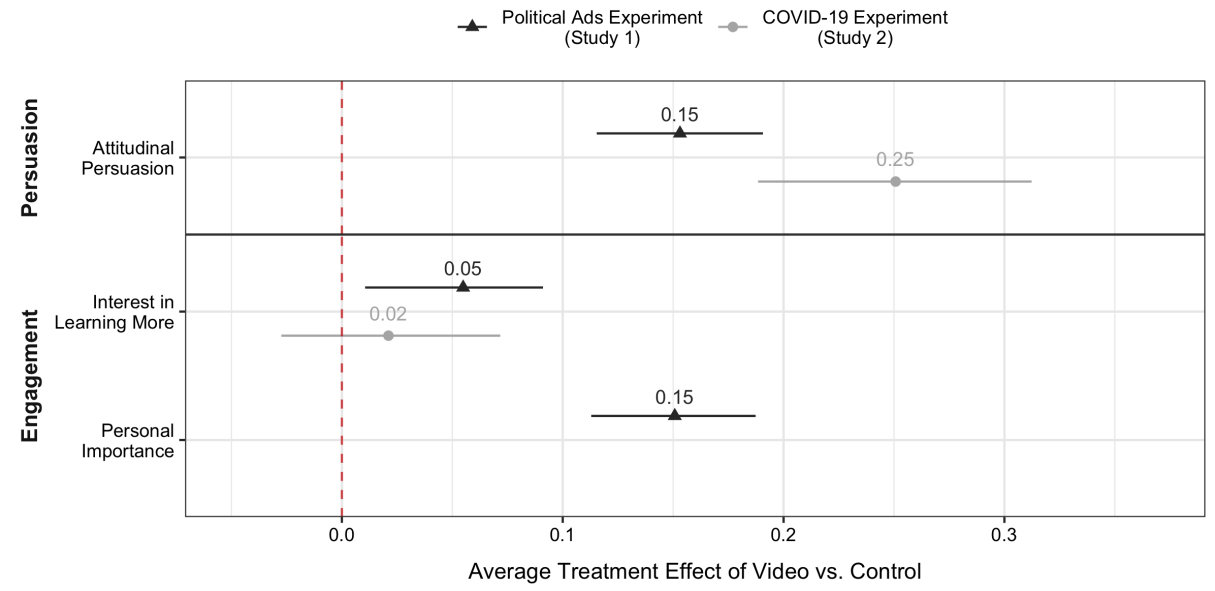

Figure S21: Average treatment effect (ATE) of assignment to the video versus control condition on ratings of persuasion and personal engagement. All estimates are expressed in terms of standard deviations. The point estimate of the ATE is based on the posterior median; specifically, we compute the median of the posterior distribution on the fixed effect parameter for the dummy variable indicating assignment to the video versus control condition. 95\% HPDIs are displayed. 


\subsection{Results Using Untransformed Dependent Variables}

The main results reported in the paper come from models with standardized dependent variables, such that the estimated effects may be interpreted in units of standard deviations. In this section, we instead display the results from models using the untransformed dependent variables, where all reported effects are expressed in terms of Likert-scale points (based on a five-point scale). Figure S22 plots the estimated ATE of assignment to video versus text, and Figure S23 plots the estimated ATE of assignment to text versus the control. Note that respondents in the control condition were not asked to rate the believability of the message or their likelihood of sharing the message with others; as such, for these two measures we do not compute ATEs for the comparison between the text and control conditions.

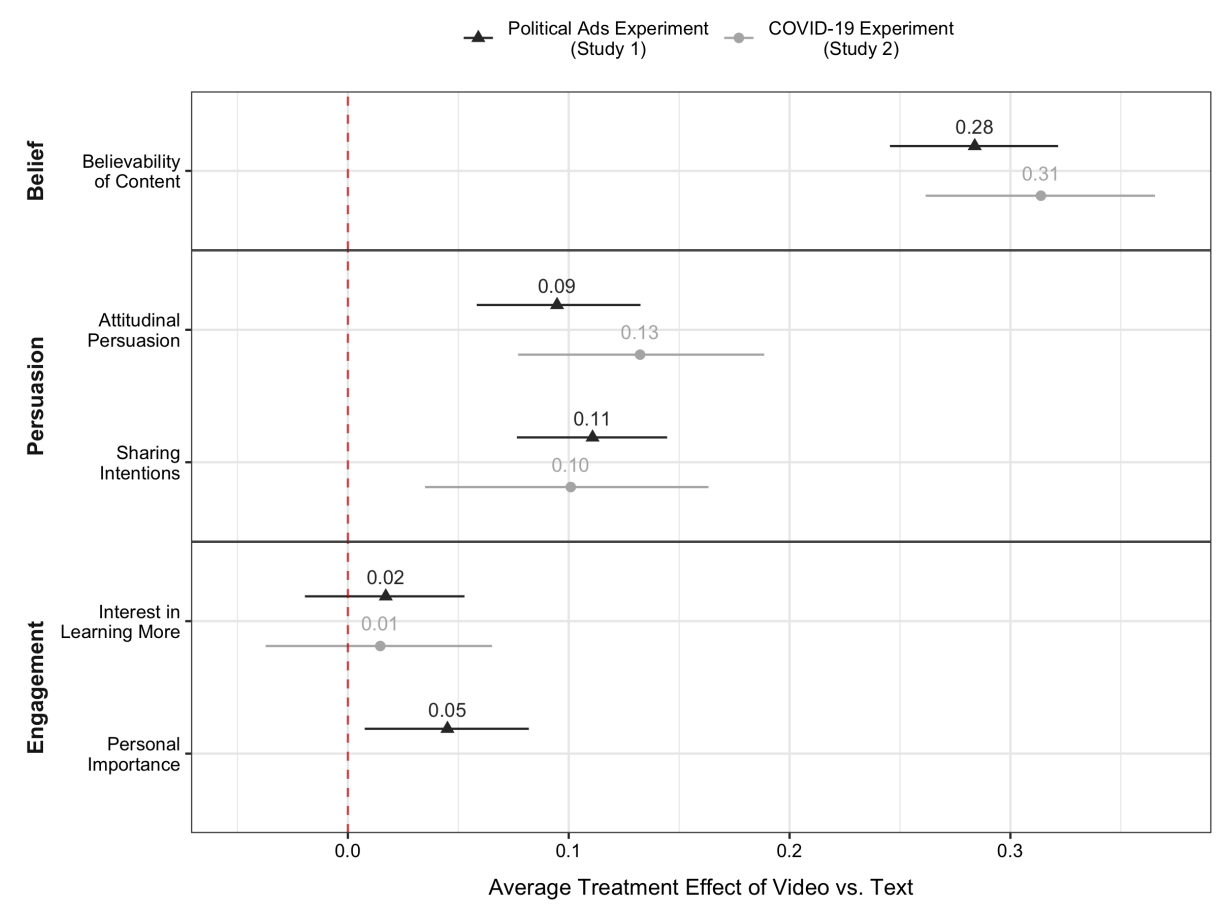

Figure S22: Average treatment effect (ATE) of assignment to the video versus text condition on ratings of believability, persuasion, and personal engagement. All items are measured using five-point scales. The point estimate of the ATE is based on the posterior median; specifically, we compute the median of the posterior distribution on the fixed effect parameter for the dummy variable indicating assignment to the video versus text condition. 95\% HPDIs are displayed. Note that ratings of personal importance are only available for Study 1. 


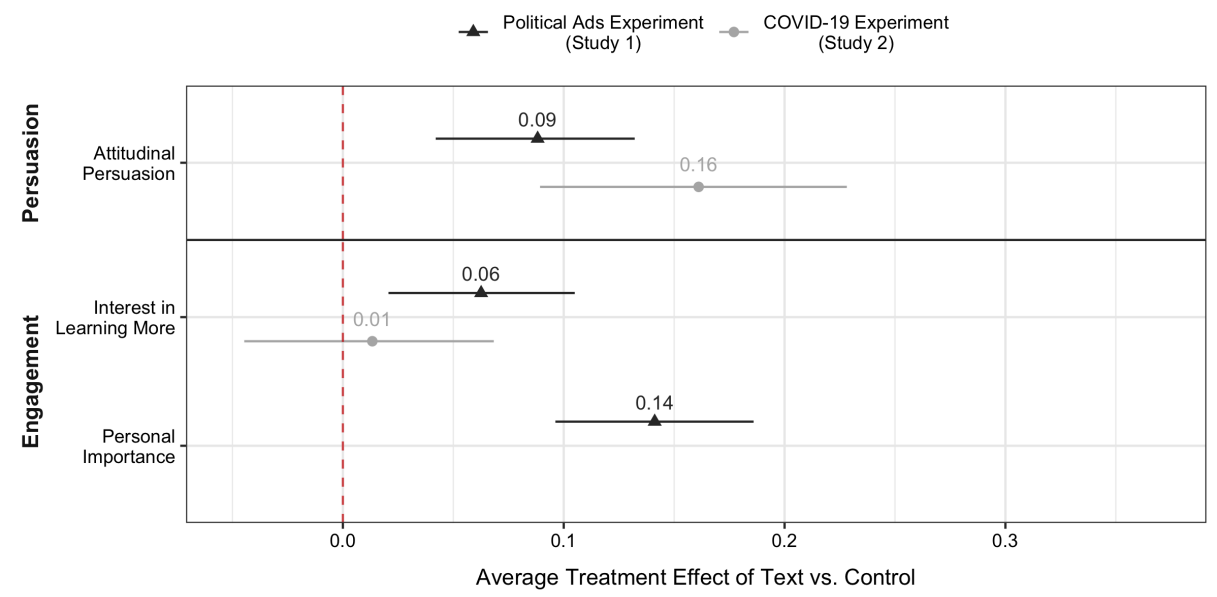

Figure S23: Average treatment effect (ATE) of assignment to the text versus control condition on ratings of persuasion and personal engagement. All items are measured using five-point scales. The point estimate of the ATE is based on the posterior median; specifically, we compute the median of the posterior distribution on the fixed effect parameter for the dummy variable indicating assignment to the text versus control condition. 95\% HPDIs are displayed. Note that ratings of personal importance are only available for Study 1.

Figure S24 plots the estimated ATE of assignment to video versus text, disaggregated by persuasive message. The top panel presents differences in believability across the video and text conditions, and the bottom panel presents differences in attitudes across these two conditions. Effects are shaded based on the study in which each message appeared (Study 1 in black, Study 2 in gray); messages from Study 1 are also labeled using the s1 prefix, whereas messages from Study 2 are identified using the s 2 prefix. Additional details about the content of each message are available in Tables S2 and S3. Note that, due to the use of multi-level modeling (see Section 2.1), these message-level effects are mildly regularized. As a robustness check, in Section 5.1 we report results from a series of OLS models estimating the difference in means between the video and text conditions for each message. 

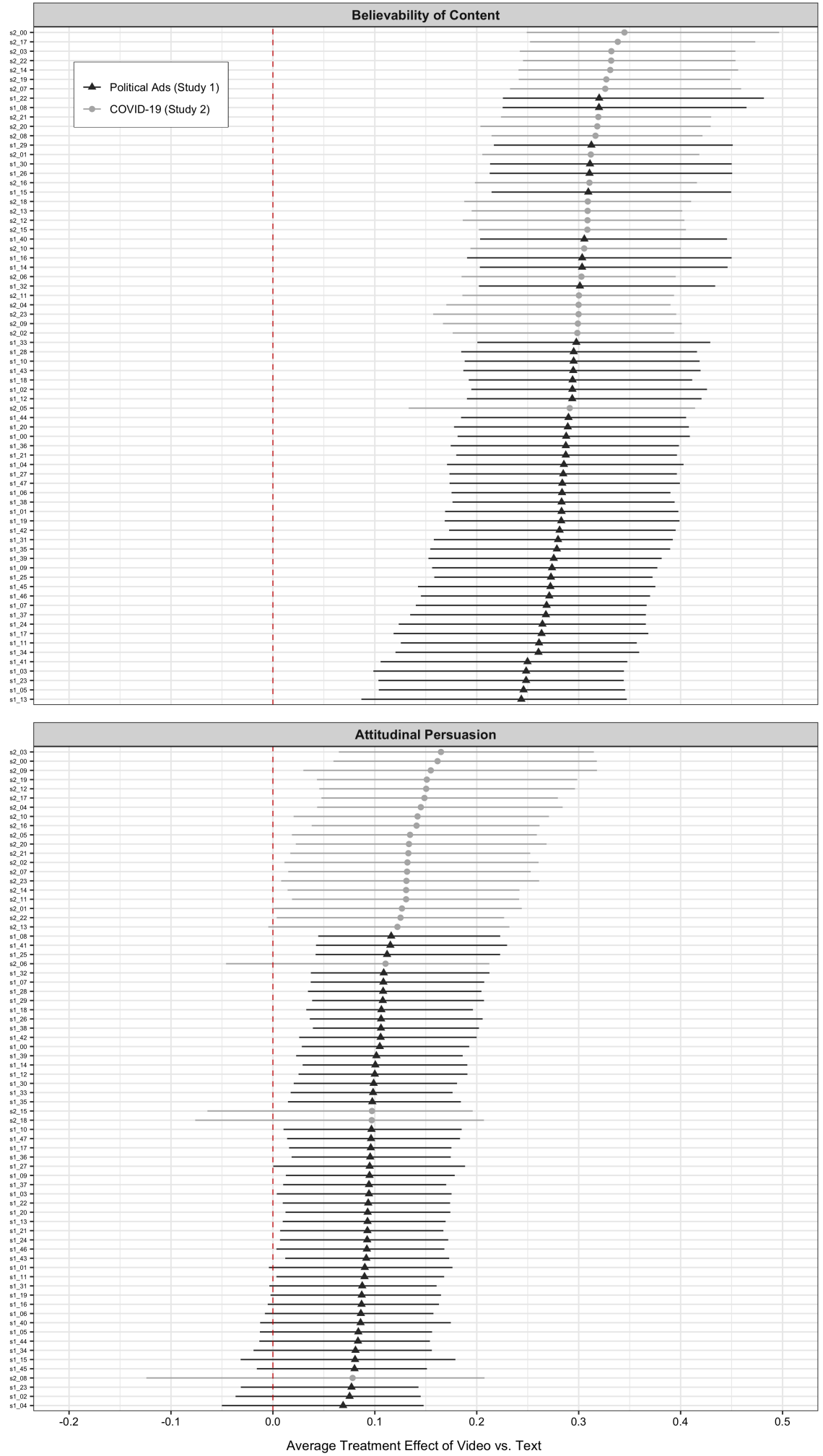

Figure S24: Average treatment effect of assignment to the video versus text condition, disaggregated by persuasive message. All items are measured using five-point scales. Posterior medians and 95\% HPDIs are displayed. 


\subsection{Moderator Models}

Figures S25 and S26 show the main results for our moderator analyses. Figure S25 plots the estimates for models with standardized dependent variables (expressed in terms of standard deviations of the outcome scale), and Figure S26 plots the estimates for models with untransformed dependent variables (expressed in terms of Likert-scale points). As noted in Section 2.2, all moderator variables are treated as continuous. Note that ratings of personal importance (shown in the bottom row of each plot) were only measured for Study 1 . In addition, because Study 1 contained exclusively political clips, comparisons of political versus non-political videos (shown in the right-most column of each plot) are only available for Study 2.

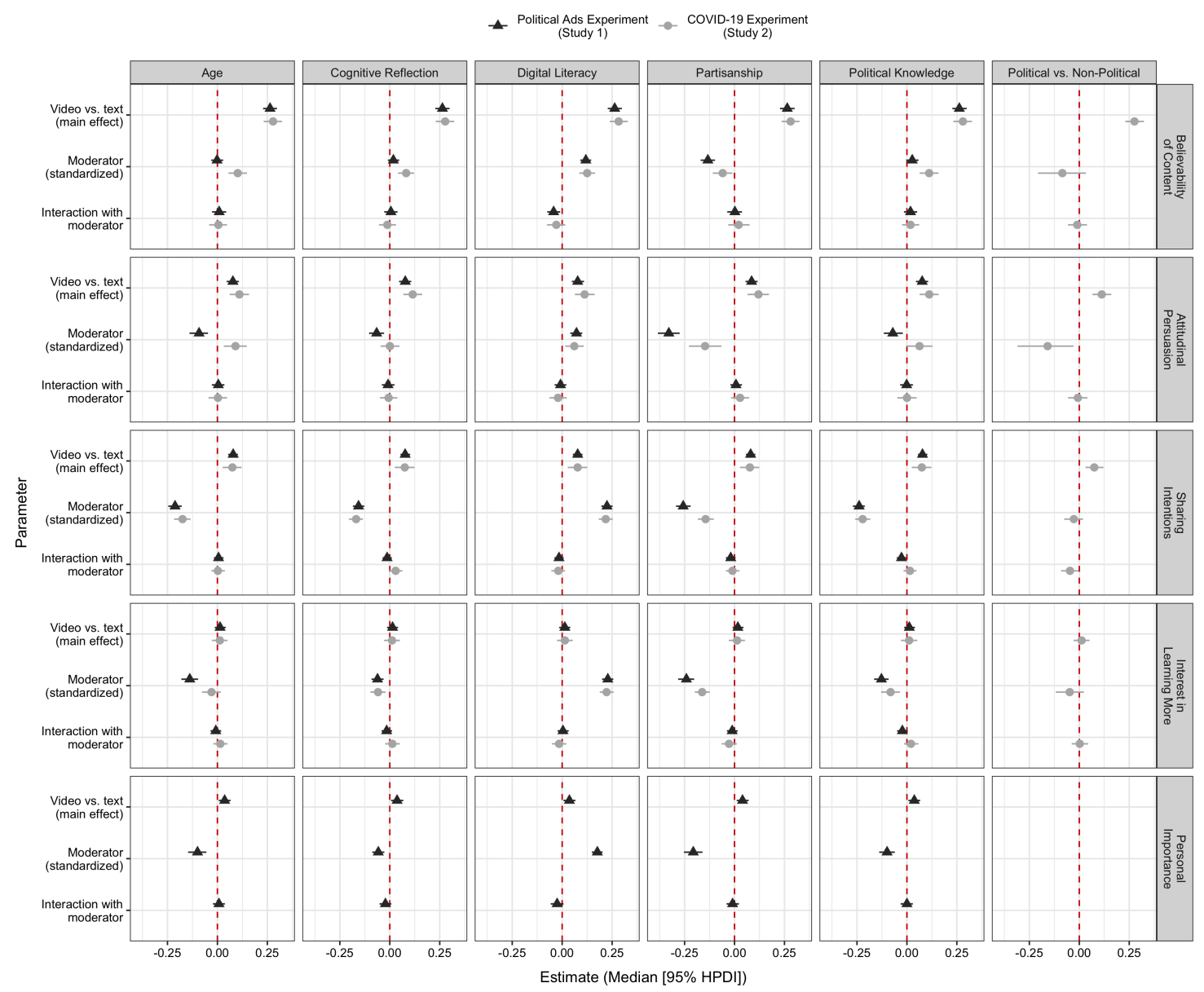

Figure S25: Differences in the average treatment effect of assignment to the video versus text condition based on respondent characteristics (age, cognitive reflection, digital literacy, partisanship, and political knowledge) and message characteristics (political vs. non-political, Study 2 only), with standardized dependent variables. The moderator variables in all cases are standardized, and the posterior medians and 95\% HPDIs are displayed. Note that personal importance was only asked in Study 1. 


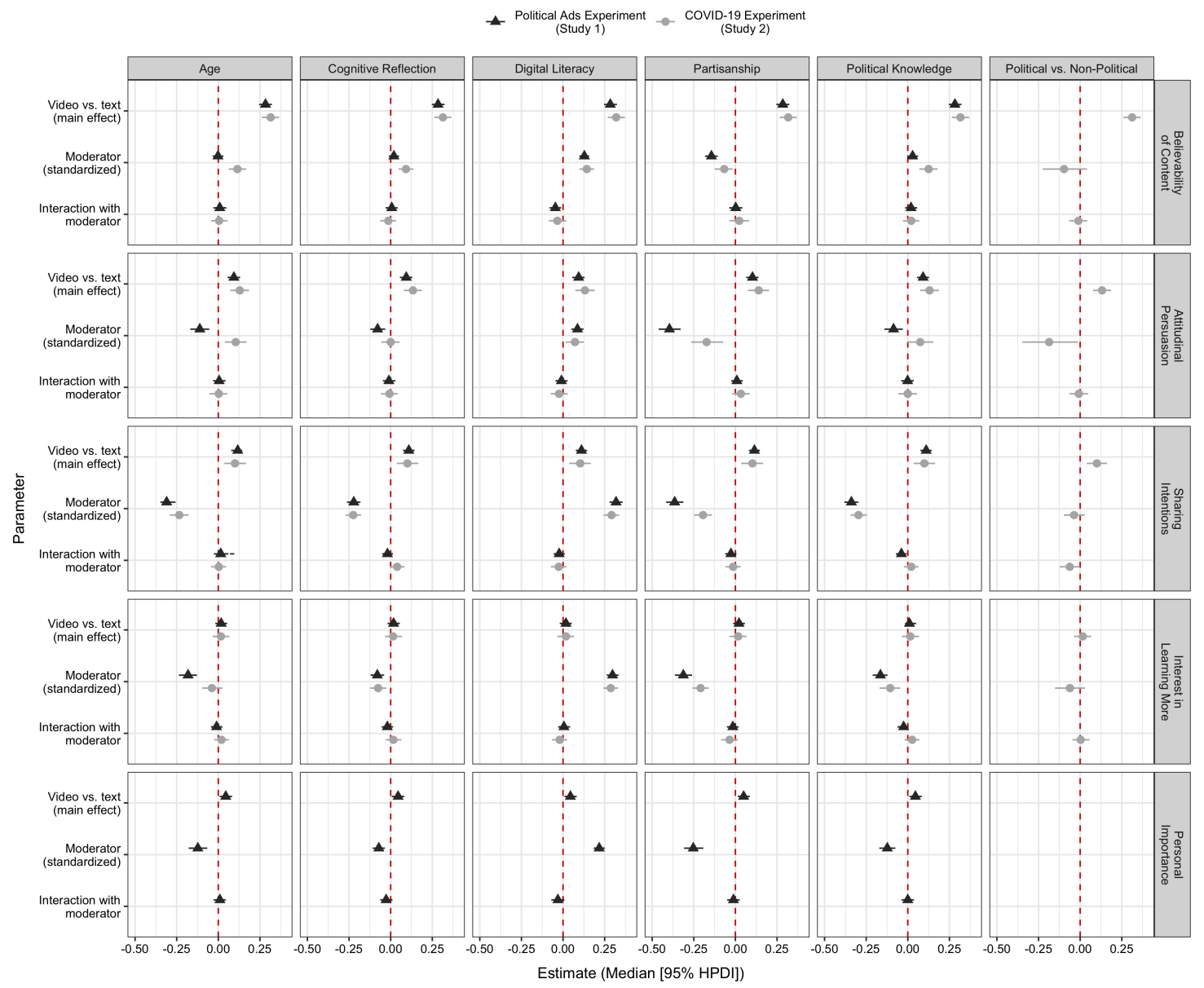

Figure S26: Differences in the average treatment effect of assignment to the video versus text condition based on respondent characteristics (age, cognitive reflection, digital literacy, partisanship, and political knowledge) and message characteristics (political vs. non-political, Study 2 only), with untransformed dependent variables. The moderator variables in all cases are standardized, and the posterior medians and 95\% HPDIs are displayed. Note that personal importance was only asked in Study 1. 


\section{Robustness Checks}

\subsection{OLS Models}

The following section presents naïve estimates of our average treatment effects from pooled OLS models with standard errors clustered by respondent. Figures S27 and S28 plot ATE estimates from models with standardized dependent variables, whereas Figures S29 and S30 plot ATE estimates from models with untransformed dependent variables. Overall, the estimated effects are nearly identical - in both size and direction - to the results using our Bayesian multi-level models, suggesting the robustness of our findings to alternative model specifications.

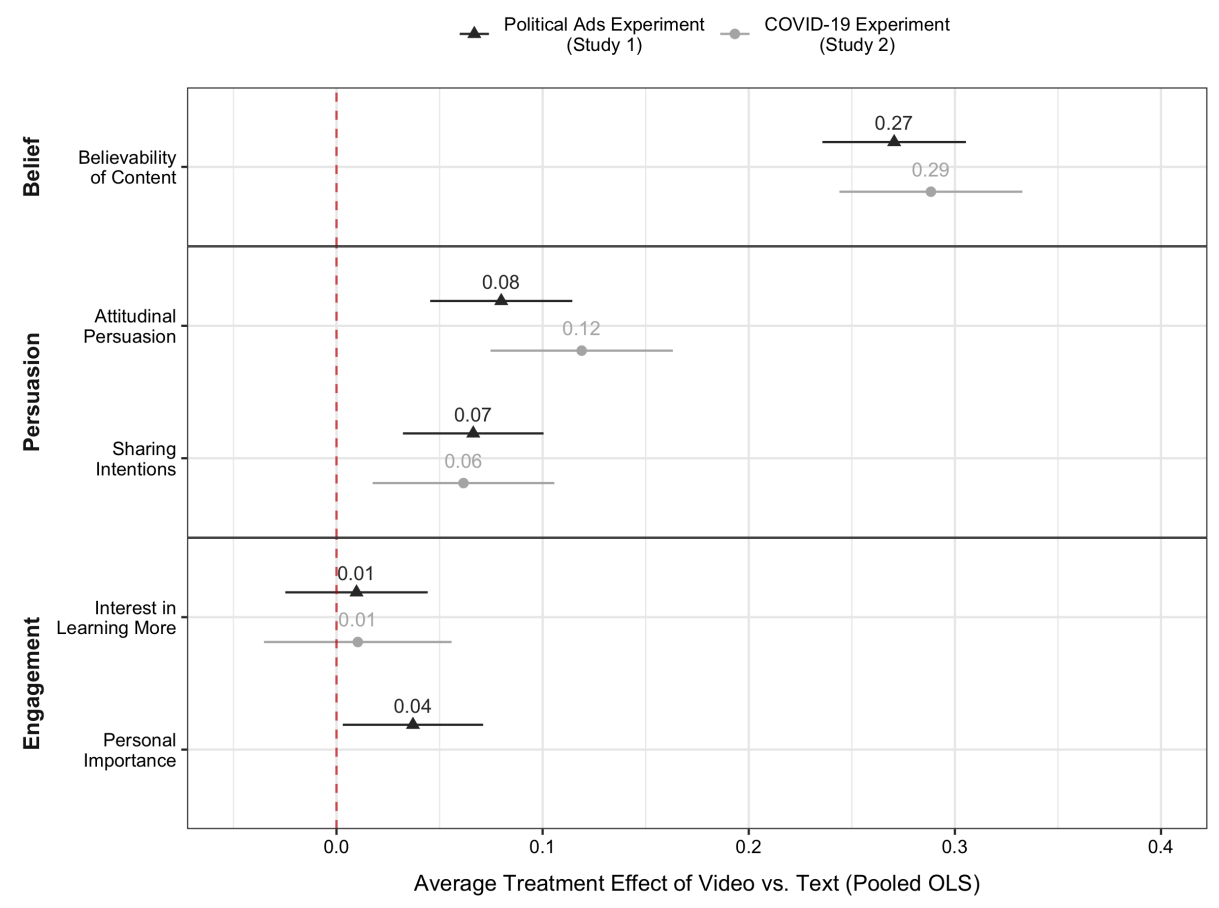

Figure S27: Average treatment effect (ATE) of assignment to the video versus text condition on ratings of believability, persuasion, and personal engagement. All estimates are expressed in terms of standard deviations. Estimated effects and 95\% confidence intervals come from pooled OLS models with standard errors clustered by respondent. Note that ratings of personal importance are only available for Study 1. 


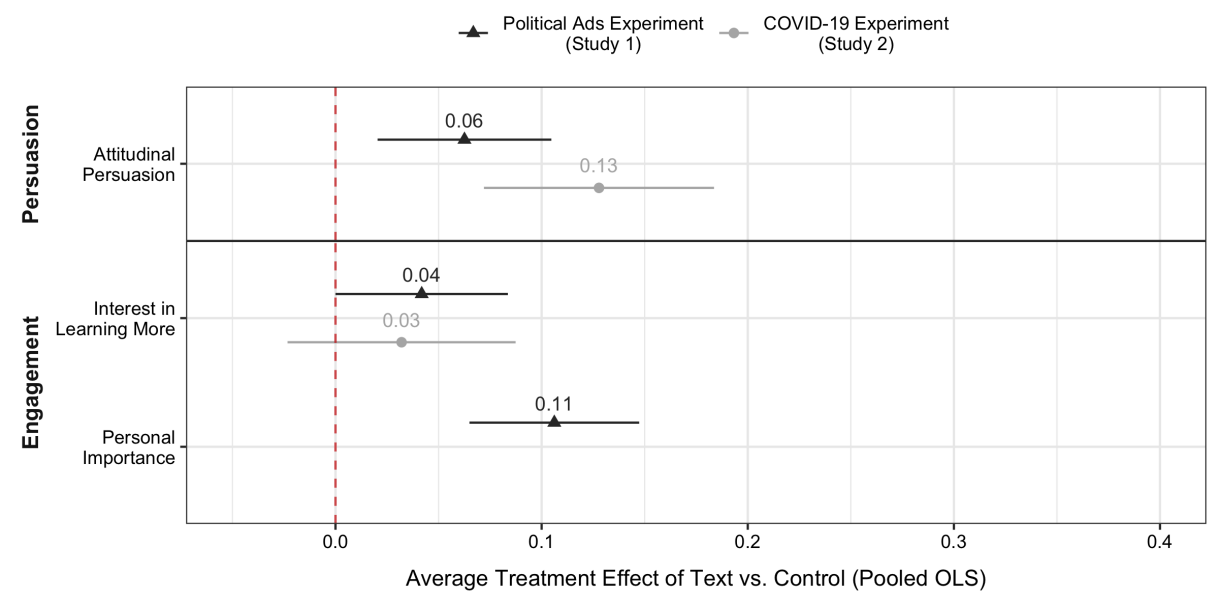

Figure S28: Average treatment effect (ATE) of assignment to the text versus control condition on ratings of persuasion and personal engagement. All estimates are expressed in terms of standard deviations. Estimated effects and $95 \%$ confidence intervals come from pooled OLS models with standard errors clustered by respondent. Note that ratings of personal importance are only available for Study 1.

\section{Results Using Untransformed Dependent Variables}

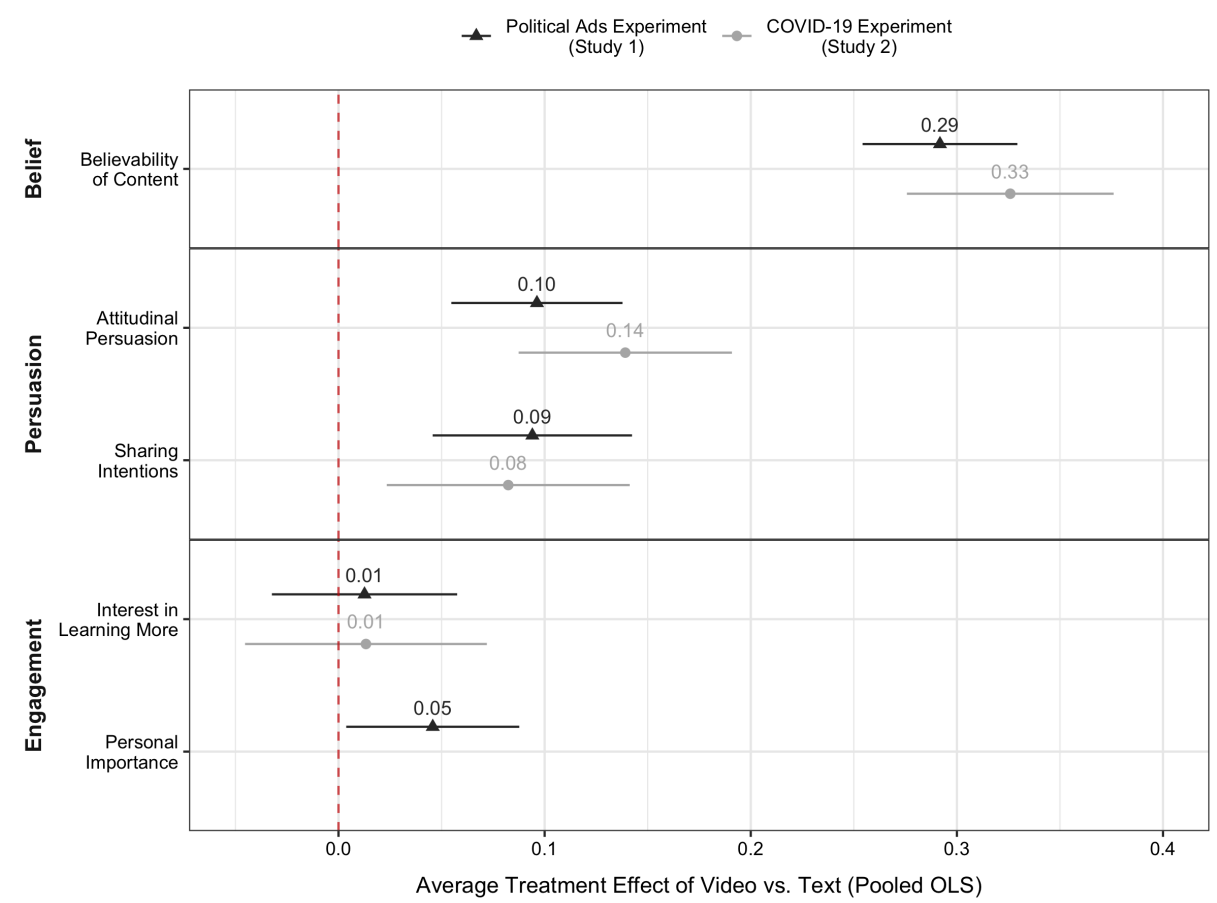

Figure S29: Average treatment effect (ATE) of assignment to the video versus text condition on ratings of believability, persuasion, and personal engagement. All items are measured using five-point scales. Estimated effects and 95\% confidence intervals come from pooled OLS models with standard errors clustered by respondent. Note that ratings of personal importance are only available for Study 1. 


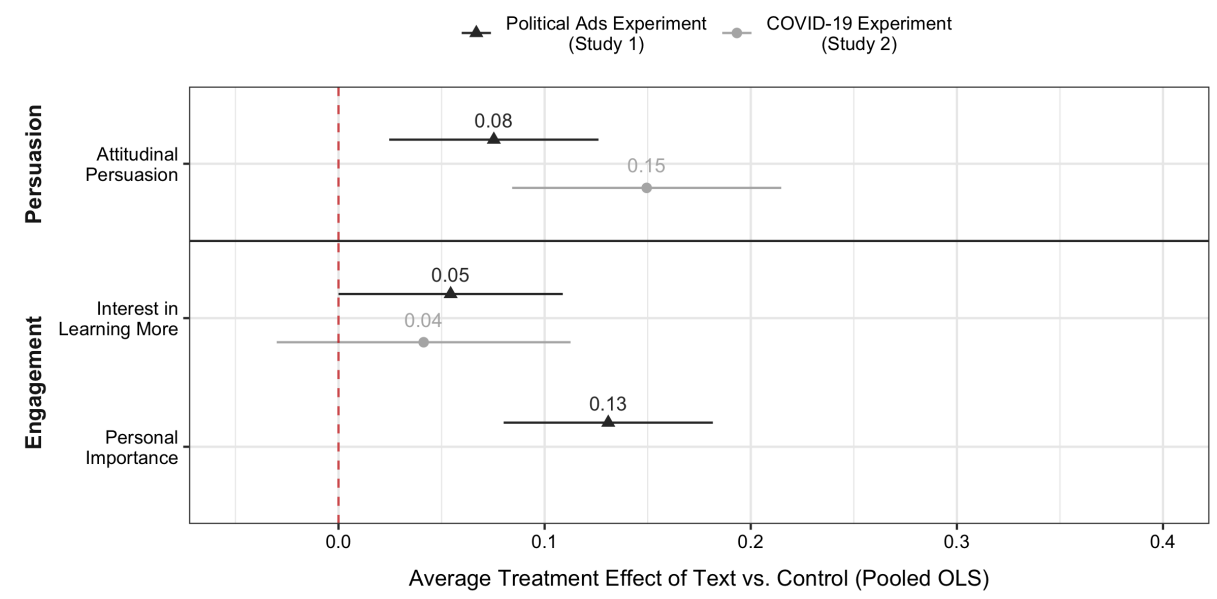

Figure S30: Average treatment effect (ATE) of assignment to the text versus control condition on ratings of persuasion and personal engagement. All items are measured using five-point scales. Estimated effects and $95 \%$ confidence intervals come from pooled OLS models with standard errors clustered by respondent. Note that ratings of personal importance are only available for Study 1.

\section{Message-Specific Analyses}

Figures S31 and S32 plot the estimated treatment effects of assignment to video versus text, disaggregated by persuasive message. For each persuasive message, we run a separate OLS model estimating the difference in means between respondents assigned to the video versus text condition. Figure S31 plots ATE estimates from models with standardized dependent variables, whereas Figure S32 plots ATE estimates from models with untransformed dependent variables. Effects are shaded based on the study in which each message appeared (Study 1 in black, Study 2 in gray); messages from Study 1 are also labeled using the s1 prefix, whereas messages from Study 2 are identified using the s2 prefix. Additional information about the content of each message is listed in Tables S2 and S3. 

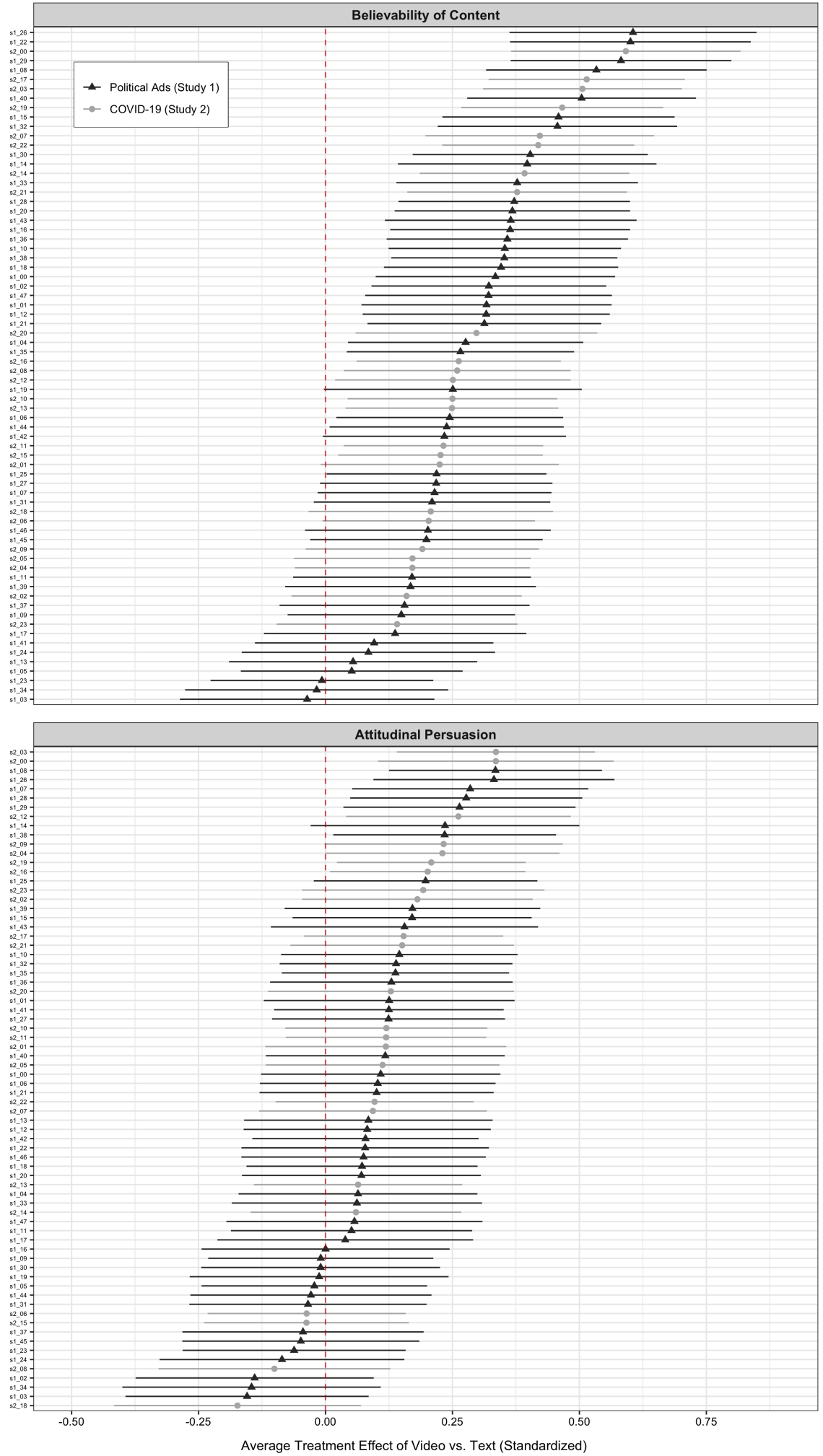

Figure S31: Average treatment effect of assignment to the video versus text condition, disaggregated by persuasive message. All estimates are expressed in terms of standard deviations. Estimated effects and 95\% confidence intervals come from OLS models with robust standard errors (HC2 variant). 

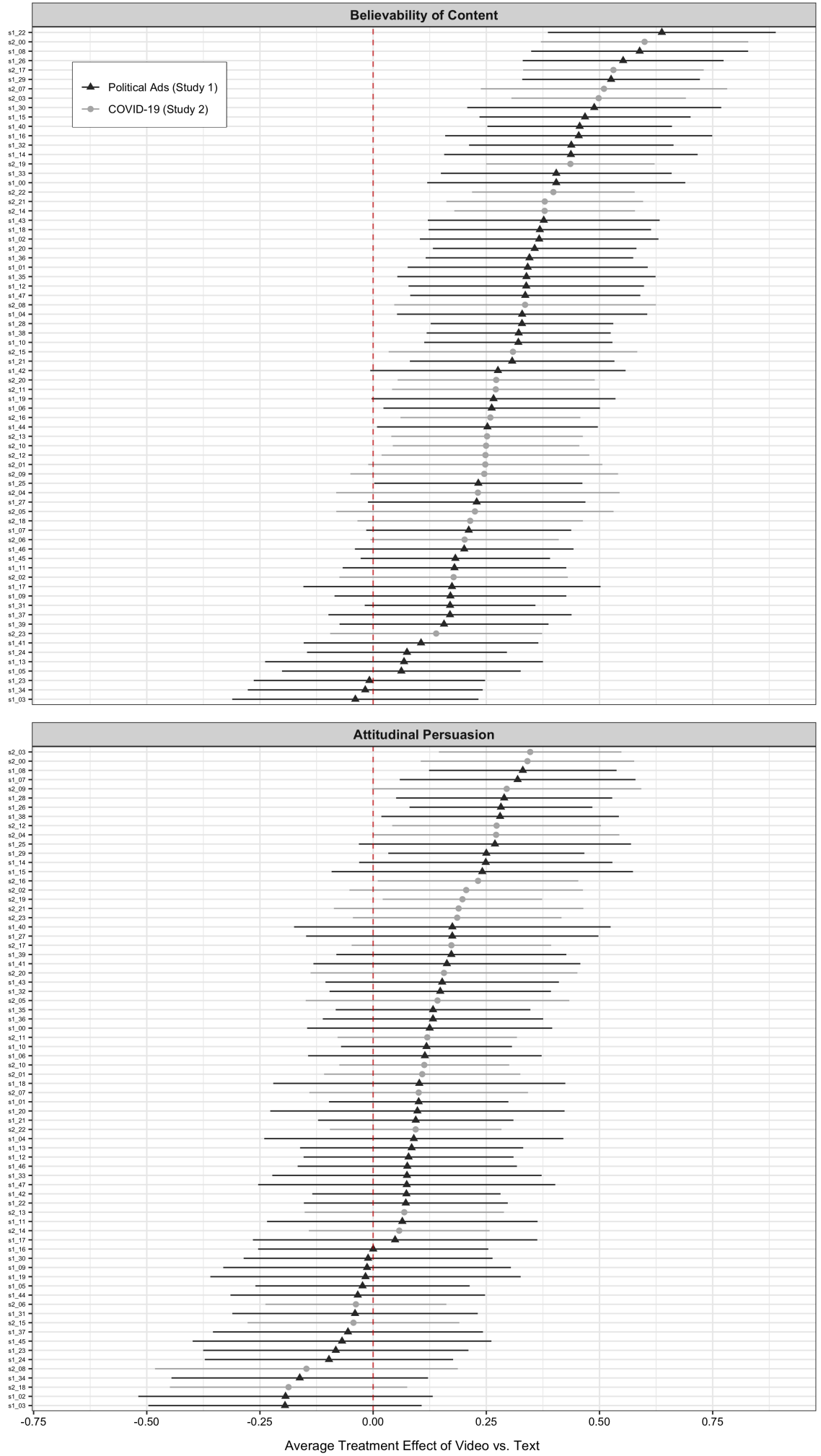

Figure S32: Average treatment effect of assignment to the video versus text condition, disaggregated by persuasive message. All items are measured using five-point scales. Estimated effects and 95\% confidence intervals come from OLS models with robust standard errors (HC2 variant). 


\subsection{Models without Respondent-Level Random Effects}

For both Studies 1-2, we had relatively little data at the respondent level, given that respondents were shown a maximum of 3-4 messages per experiment. Given this, as shown in Section 2.2, the chains for our subject-level random effects were not sufficiently well-mixed for all parameters and models. In this section, we report the results from models that exclude these subject-level random effects. Across both studies, we find substantively identical results after removing these random effects, providing further evidence that our results are robust to alternative model specifications. Summaries of the posterior distribution and convergence diagnostics, as well as trace plots, are available on OSF (https://osf.io/xwmqn/).

\section{Study 1}

Figures S33 and S34 plot the average treatment effects of assignment to the video vs. text and text vs. control conditions in Study 1 across model specifications. In addition, Figure S35 plots the results of moderator analyses across our two model specifications. The dependent variable in all cases is standardized.

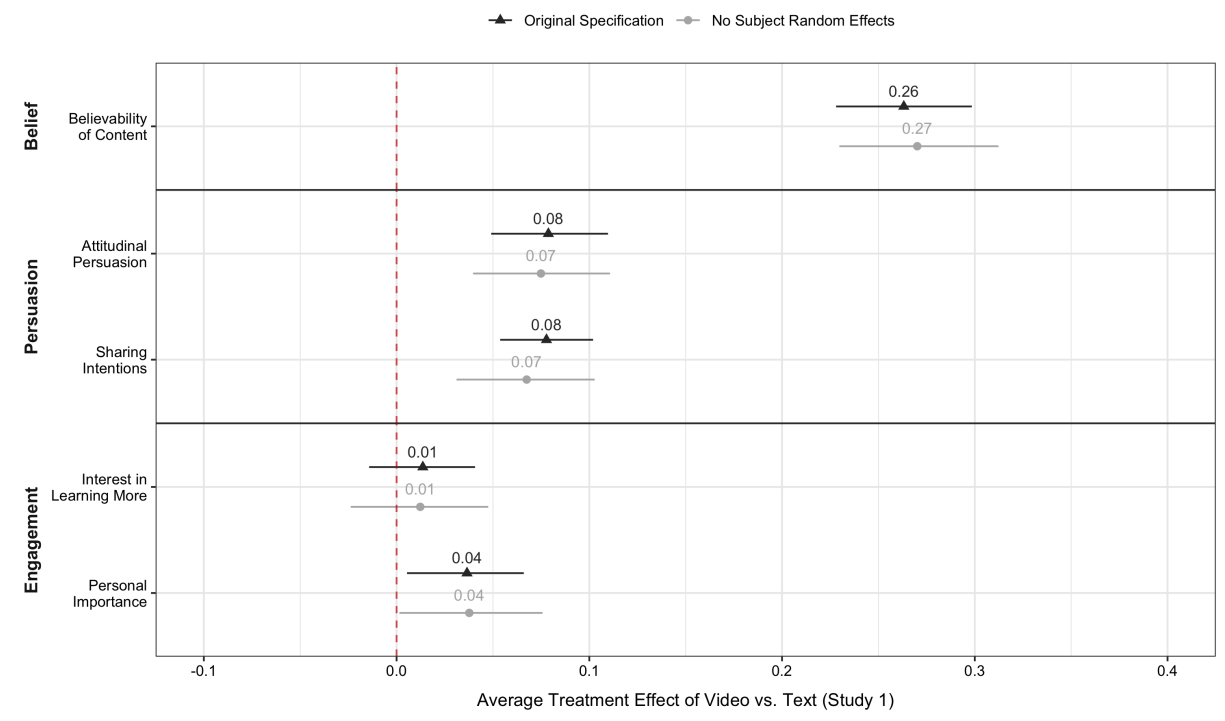

Figure S33: Average treatment effect (ATE) of assignment to the video versus text condition in Study 1 , from both the preregistered model specification and a model without subject-level random effects. All estimates are expressed in terms of standard deviations. Posterior medians and 95\% HPDIs are displayed. 


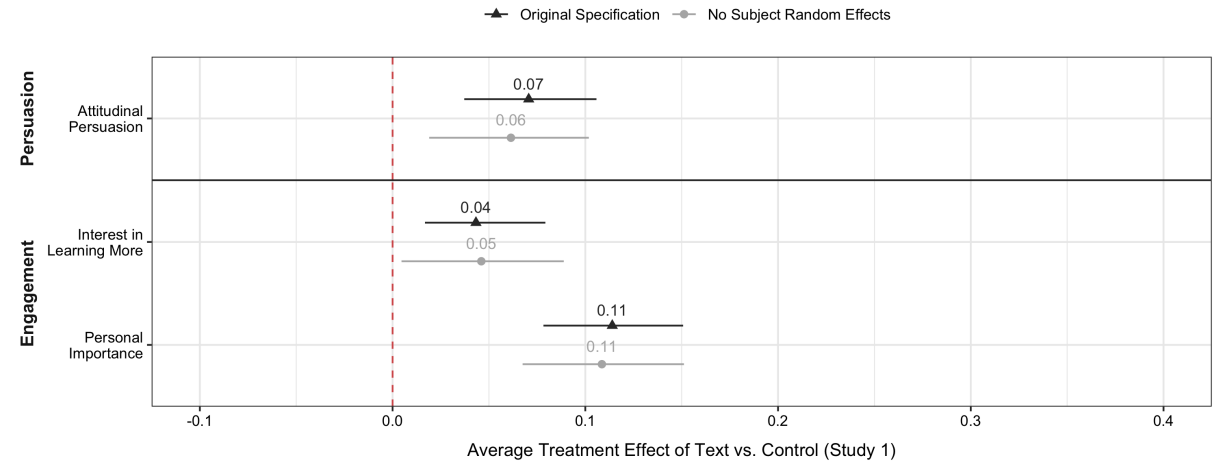

Figure S34: Average treatment effect (ATE) of assignment to the text versus control condition in Study 1 , from both the preregistered model specification and a model without subject-level random effects. All estimates are expressed in terms of standard deviations. Posterior medians and 95\% HPDIs are displayed.

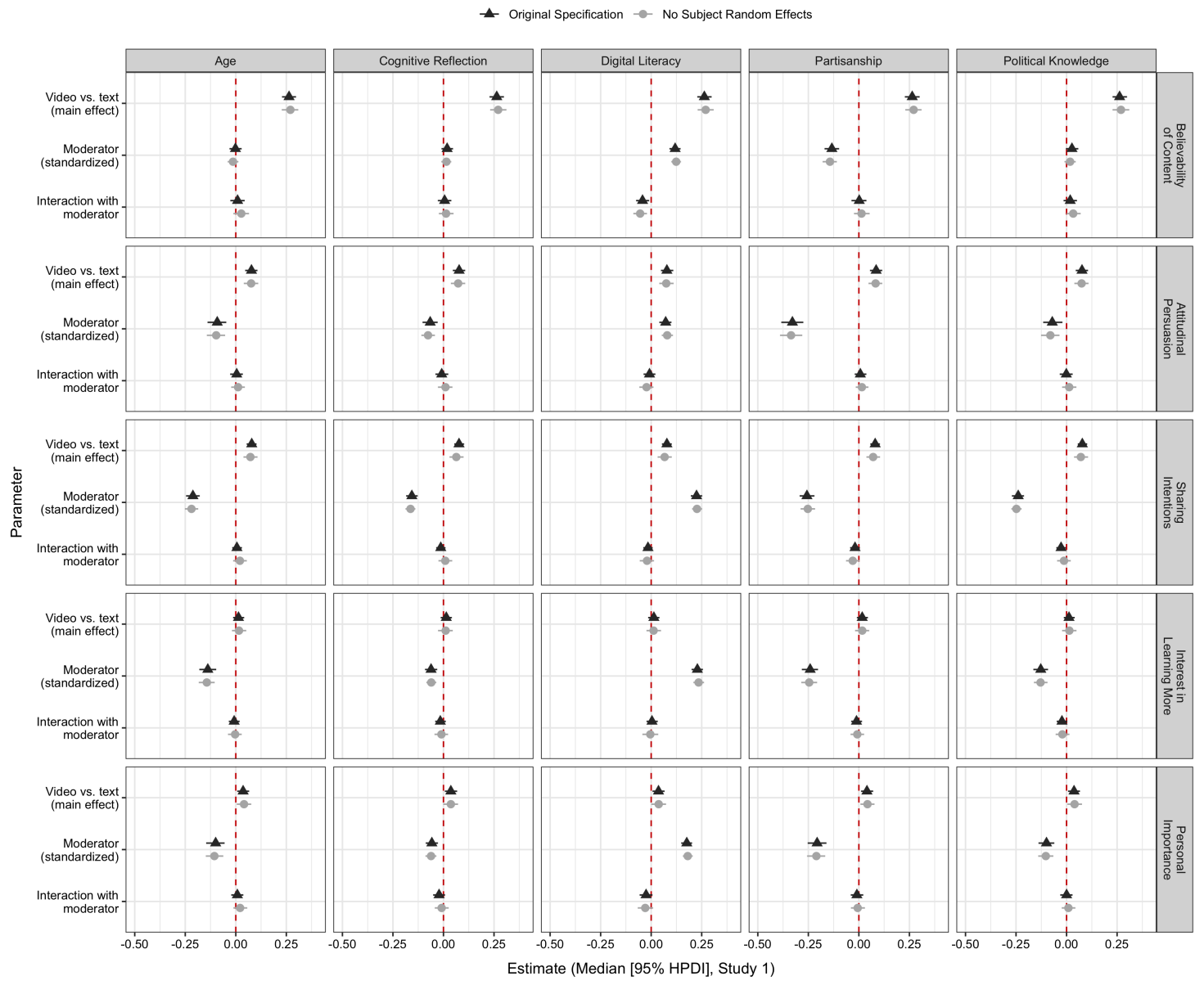

Figure S35: Differences in the average treatment effect of assignment to the video versus text condition based on respondent characteristics (age, cognitive reflection, digital literacy, partisanship, and political knowledge) in Study 1, with standardized dependent variables. Estimates come from both the preregistered model specification and a model without subject-level random effects. The moderator variables in all cases are standardized, and the posterior medians and 95\% HPDIs are displayed. 


\section{Study 2}

In this section, we plot key parameter estimates from Bayesian multi-level models both with and without respondent-level random effects for Study 2. Figures S36 and S37 plot the average treatment effects of assignment to the video vs. text and text vs. control conditions, respectively, across model specifications. In addition, Figure S38 plots the results of moderator analyses across our two model specifications. The dependent variable in all cases is standardized.

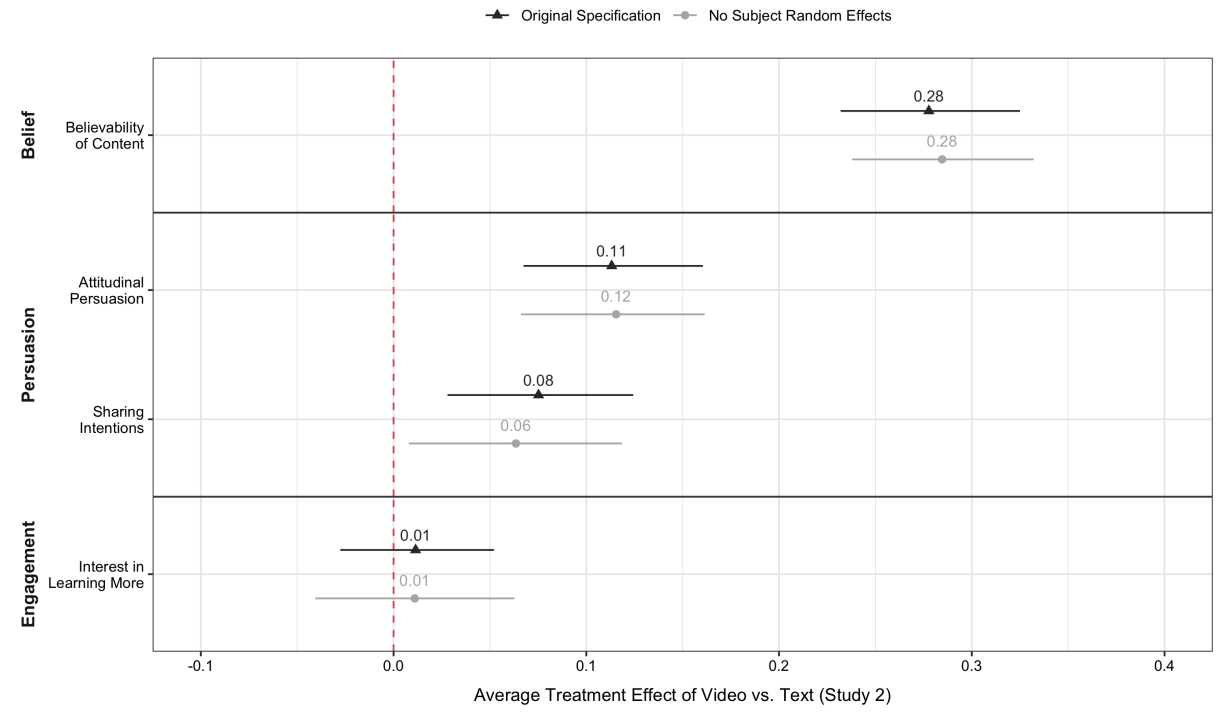

Figure S36: Average treatment effect (ATE) of assignment to the video versus text condition in Study 2, from both the preregistered model specification and a model without subject-level random effects. All estimates are expressed in terms of standard deviations. Posterior medians and 95\% HPDIs are displayed.

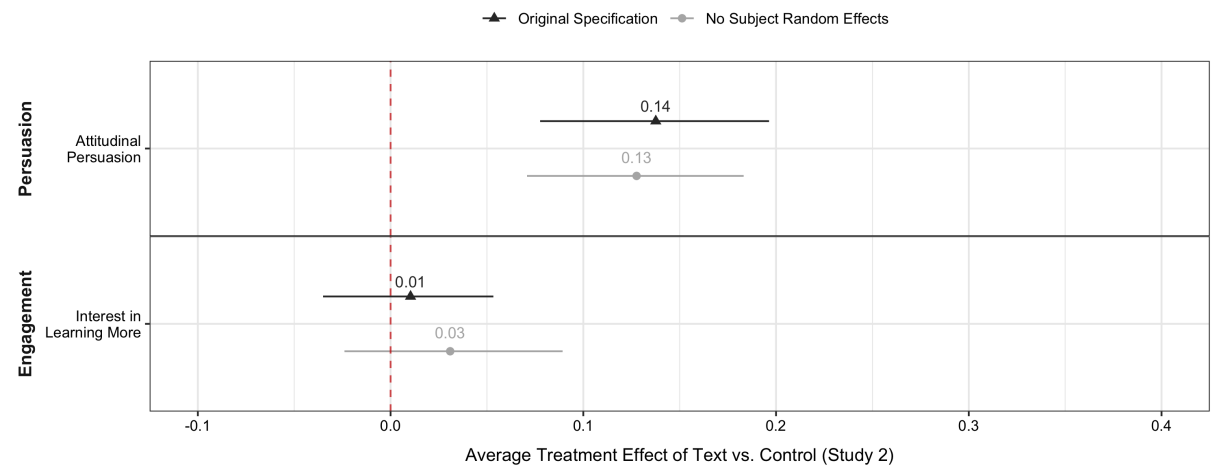

Figure S37: Average treatment effect (ATE) of assignment to the text versus control condition in Study 2, from both the preregistered model specification and a model without subject-level random effects. All estimates are expressed in terms of standard deviations. Posterior medians and 95\% HPDIs are displayed. 


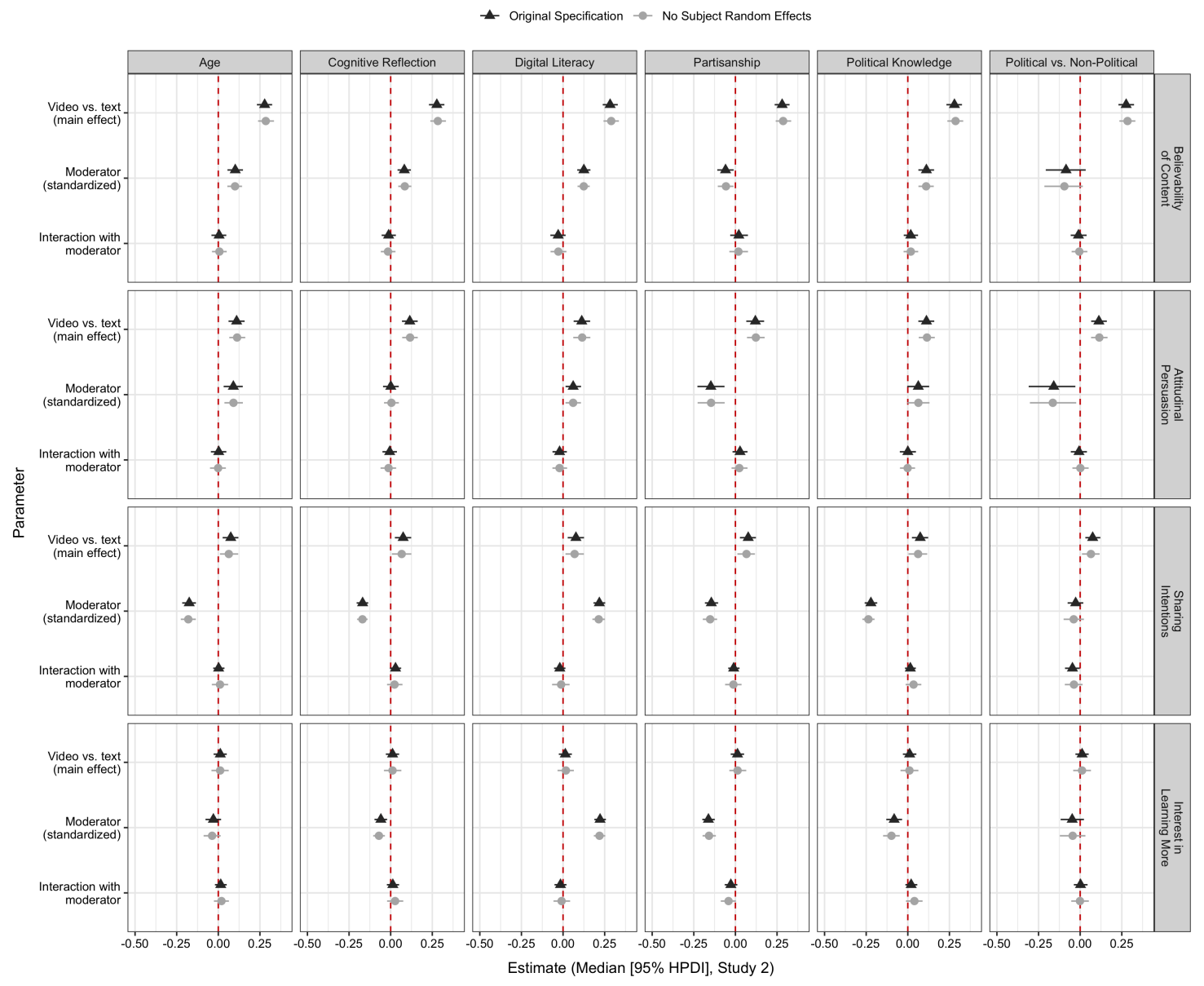

Figure S38: Differences in the average treatment effect of assignment to the video versus text condition based on respondent characteristics (age, cognitive reflection, digital literacy, partisanship, and political knowledge) and message characteristics (political vs. non-political) in Study 2, with standardized dependent variables. Estimates come from both the preregistered model specification and a model without subject-level random effects. The moderator variables in all cases are standardized, and the posterior medians and $95 \%$ HPDIs are displayed. 


\subsection{Non-Linearities in Moderator Models}

Following our preregistration, we treat each of our moderator variables as continuous. It is possible, however, that this approach masks potential non-linearities in the interaction effects (for a description of the problem, see 8). As a robustness check, we thus re-estimate each of our models using OLS. Rather than linearly interact each of our continuous moderator variables with the treatment indicator, we instead bin respondents into equally sized groups, based on their value for each moderator variable, and estimate the effect of video versus text separately within each stratum. Specifically, for each study, we bin the moderator variables into both terciles and quintiles. The estimates in all cases are expressed in units of standard deviation. Given the use of pooled OLS, standard errors are clustered by respondent. Figures S39 and S40 plot the resulting estimates for Study 1, and Figures S41 and S42 plot the estimates for Study 2.

Overall, we do not find that our treatment of the moderator variables as continuous obscured meaningful non-linearity in treatment effects across groups. Although there are some cases where the treatment effects are marginally larger for one group of participants (e.g., less digitally literate respondents in Study 1, more intuitive thinkers in Study 2), these slight differences in effects are substantively small and inconsistent across our two studies. Moreover, the sign of the effects in all cases remains uniform across groups, indicating relative consistency in treatment effects across sub-populations.

\section{Study 1}

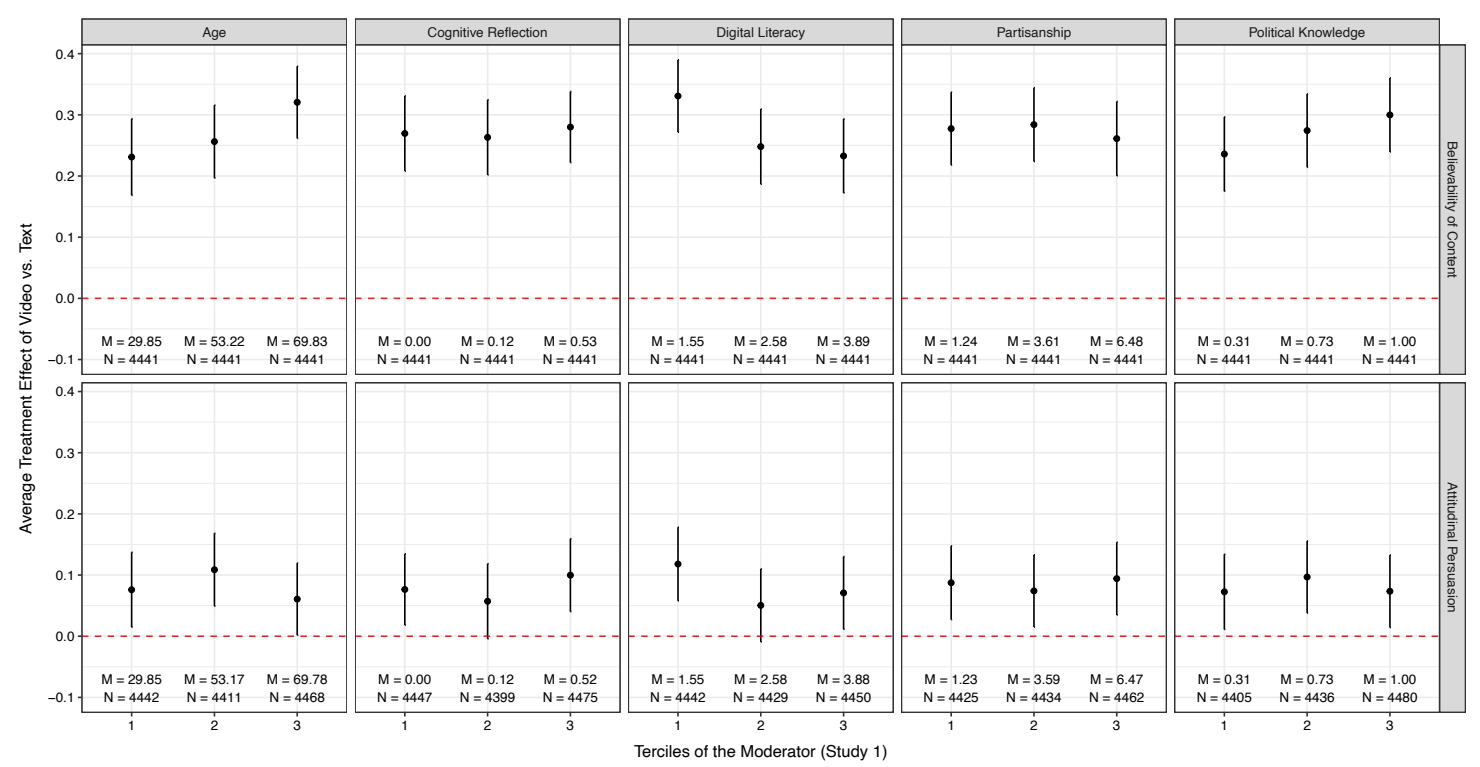

Figure S39: Differences in the average treatment effect of assignment to the video versus text condition across respondent sub-populations for Study 1. To calculate these treatment effects, we bin respondents in terciles for each moderator variable and estimate the difference in means between the video and text conditions within each bin using OLS (with standard errors clustered by respondent). The mean value of the moderator and the number of observations in each bin are displayed. 


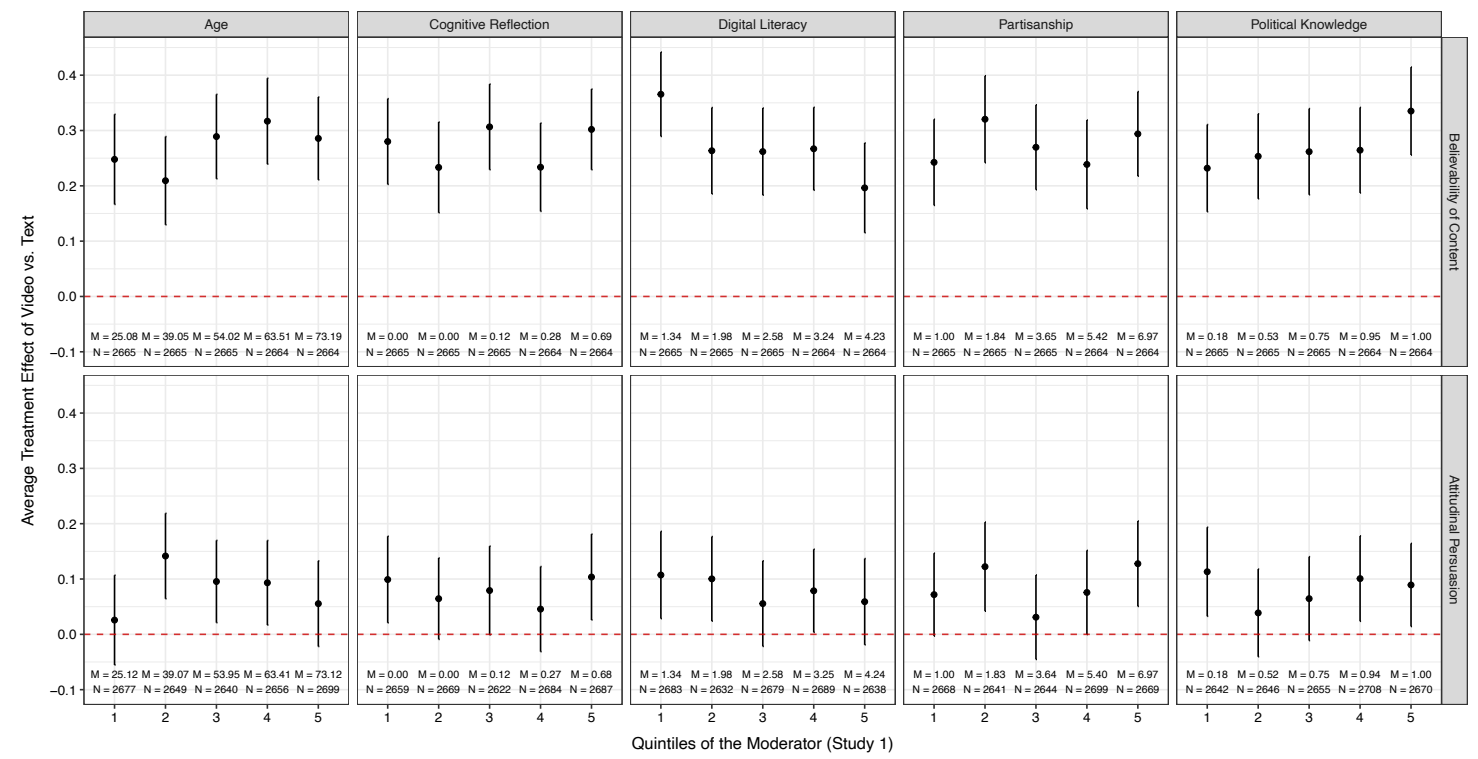

Figure S40: Differences in the average treatment effect of assignment to the video versus text condition across respondent sub-populations for Study 1. To calculate these treatment effects, we bin respondents in quintiles for each moderator variable and estimate the difference in means between the video and text conditions within each bin using OLS (with standard errors clustered by respondent). The mean value of the moderator and the number of observations in each bin are displayed.

\section{Study 2}

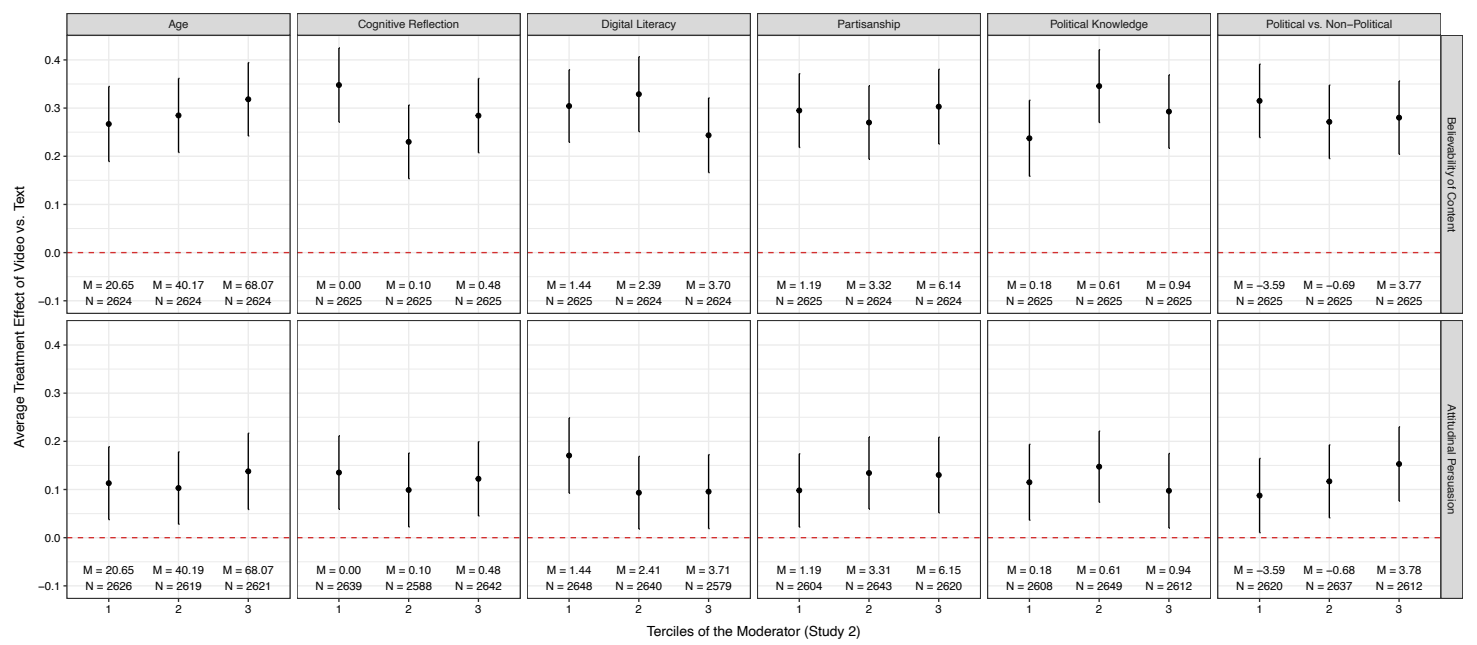

Figure S41: Differences in the average treatment effect of assignment to the video versus text condition across respondent sub-populations for Study 2. To calculate these treatment effects, we bin respondents in terciles for each moderator variable and estimate the difference in means between the video and text conditions within each bin using OLS (with standard errors clustered by respondent). The mean value of the moderator and the number of observations in each bin are displayed. 


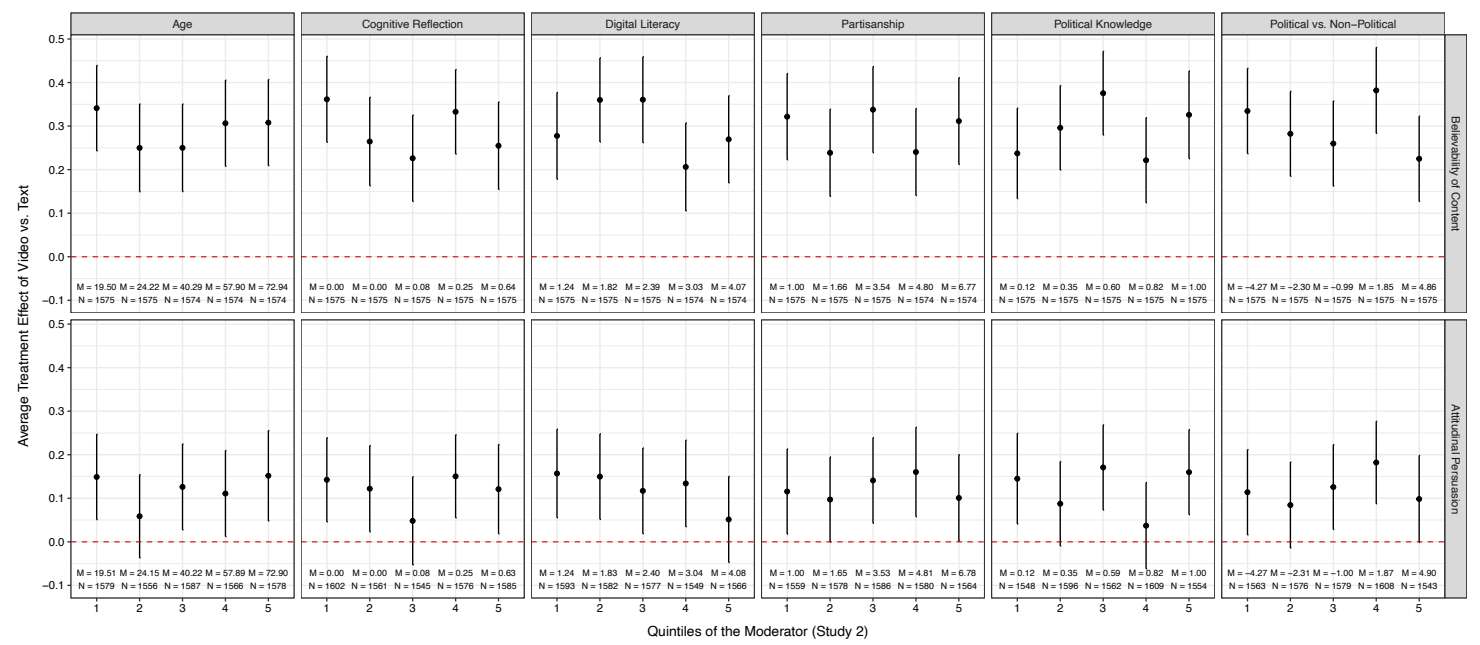

Figure S42: Differences in the average treatment effect of assignment to the video versus text condition across respondent sub-populations for Study 2. To calculate these treatment effects, we bin respondents in quintiles for each moderator variable and estimate the difference in means between the video and text conditions within each bin using OLS (with standard errors clustered by respondent). The mean value of the moderator and the number of observations in each bin are displayed. 


\subsection{Responses by Attentiveness}

As described above (Section 1.4), we took a number of steps to ensure a diverse but attentive sample of respondents for both studies, including using a stringent audiovisual check to confirm that respondents were able and willing to view video content. However, as a secondary check, we also included two instructional manipulation checks ("screeners") designed to identify respondent inattentiveness. In Figure S43, we stratify our sample by levels of attentiveness - based on the number of attention checks each respondent passed - and estimate the treatment effect of video versus text within each stratum using pooled OLS (with standard errors clustered by respondent).

Overall, almost all of our respondents passed at least one of these attention checks in both studies - and the modal respondent in Study 1 answered both attention checks correctly. In addition, we find limited variation in treatment effects across attentiveness strata. In Study 1 , we do find that the treatment effects tend to be somewhat smaller for the belief outcome and larger for the persuasion outcome among the least attentive subset of respondents. However, given the small size of this group, the resulting effect estimates are very noisy. Furthermore, as shown in Table S15 and S16, in pooled OLS models linearly interacting the treatment indicator with a continuous measure of attentiveness, we do not find significant differences in treatment effects across levels of attentiveness for either study (insignificant interaction terms, $p>0.10$ in all cases). We therefore advise caution when interpreting the observed treatment effects among low-attention respondents.

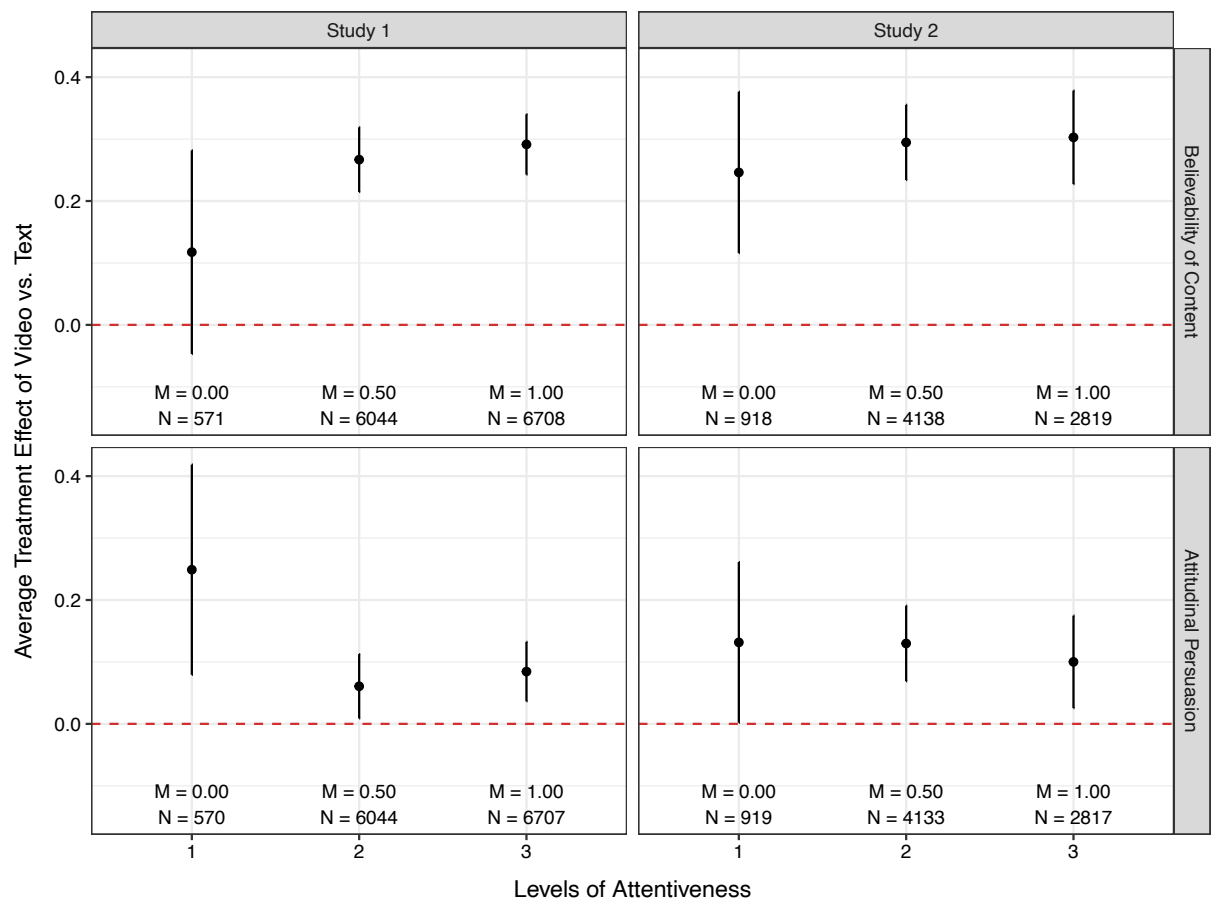

Figure S43: Differences in the average treatment effect of assignment to the video versus text condition by respondent attentiveness. To calculate these treatment effects, we estimate the difference in means between the video and text conditions at each level of attentiveness using OLS (with standard errors clustered by respondent). The count of observations in each stratum is displayed. 
Table S15: Moderation by Attentiveness - Study 1

\begin{tabular}{lccccc}
\hline & Belief & Persuade & Sharing & Importance & Learn More \\
\hline Video & $0.27^{* * *}$ & $0.08^{* * *}$ & $0.06^{* * *}$ & $0.04^{* *}$ & 0.01 \\
& $(0.02)$ & $(0.02)$ & $(0.02)$ & $(0.02)$ & $(0.02)$ \\
Attention & $0.06^{* * *}$ & 0.02 & $-0.11^{* * *}$ & $-0.03^{*}$ & $-0.04^{* *}$ \\
& $(0.01)$ & $(0.01)$ & $(0.02)$ & $(0.01)$ & $(0.02)$ \\
Video $\times$ Attention & 0.03 & -0.01 & 0.01 & -0.0002 & -0.01 \\
& $(0.02)$ & $(0.02)$ & $(0.02)$ & $(0.02)$ & $(0.02)$ \\
Constant & $-0.14^{* * *}$ & $-0.04^{* * *}$ & $-0.03^{*}$ & -0.02 & -0.003 \\
& $(0.01)$ & $(0.01)$ & $(0.02)$ & $(0.01)$ & $(0.02)$ \\
\hline $\mathrm{N}$ & 13323 & 13321 & 13313 & 13317 & 13312 \\
R-squared & 0.02 & 0.002 & 0.01 & 0.001 & 0.001 \\
\hline
\end{tabular}

${ }^{* * *} \mathrm{p}<.01 ;{ }^{* *} \mathrm{p}<.05 ;{ }^{*} \mathrm{p}<.1$

Table S16: Moderation by Attentiveness - Study 2

\begin{tabular}{lcccc}
\hline & Belief & Persuade & Sharing & Learn More \\
\hline Video & $0.29^{* * *}$ & $0.12^{* * *}$ & $0.06^{* * *}$ & 0.01 \\
& $(0.02)$ & $(0.02)$ & $(0.02)$ & $(0.02)$ \\
Attention & $0.15^{* * *}$ & $0.14^{* * *}$ & $-0.12^{* * *}$ & $-0.03^{*}$ \\
& $(0.02)$ & $(0.02)$ & $(0.02)$ & $(0.02)$ \\
Video $\times$ Attention & 0.01 & -0.02 & 0.01 & 0.03 \\
& $(0.02)$ & $(0.02)$ & $(0.02)$ & $(0.02)$ \\
Constant & $-0.15^{* * *}$ & $-0.06^{* * *}$ & -0.03 & -0.004 \\
& $(0.02)$ & $(0.02)$ & $(0.02)$ & $(0.02)$ \\
\hline $\mathrm{N}$ & 7875 & 7869 & 7860 & 7866 \\
R-squared & 0.04 & 0.02 & 0.01 & 0.001 \\
\hline
\end{tabular}

${ }^{* * *} \mathrm{p}<.01 ;{ }^{* *} \mathrm{p}<.05 ;{ }^{*} \mathrm{p}<.1$ 


\section{Spring 2019 Pilot Study}

In May and June of 2019, we conducted a preregistered pilot study that assessed the relative persuasive advantage of video versus text across six stories (three political and three non-political). Participants were recruited via Lucid Theorem, which uses quota matching to obtain a diverse national sample of respondents that matches U.S. Census demographics in terms of age, gender, race/ethnicity, and census region (9). Data were collected in three waves. In the first two rounds of data collection $(n=616)$, participants were required to view all six experimental stimuli. Due to concerns about protracted response times and high attrition rates, the final round of data collection $(n=4370)$ utilized a streamlined version of the survey, wherein respondents were required to view a random sample of only four of the six stimuli. For each story, participants were randomly assigned to view either a short video clip or an annotated transcript of the video clip. Following our preregistration, we removed any participants who participated in multiple rounds of data collection or were unable to play the videos, leading to a final sample of $n=4808$ Americans (20,428 total observations).

\subsection{Experimental Design}

\section{Stimulus Selection}

For this initial study, we selected a diverse set of six video clips that met the following criteria:

1. Contained a persuasive message: we sought out videos that contained some form of persuasive messaging, in order to determine whether respondents' attitudes and behavior are more strongly shaped by video versus text.

2. Depicted people/events:

- We included videos that showed events occurring or claims being made on screen, so that we could assess whether respondents believed these events actually occurred.

- We avoided videos that were solely composed of animation or "voiceover pictures." Though these types of videos frequently involve persuasive messaging, they do not typically show footage of events. As a result, it is difficult to measure whether respondents believed the depicted events really took place.

3. Short duration: because of our use of a within-subject design, wherein respondents viewed up to six different stories, we only included videos that were less than one minute in length (ranging from 3 to 51 seconds).

4. Clear footage: we avoided including any videos that were low-resolution or were overly compressed.

With these criteria in mind, we sought out several types of clips. First, we considered the origin of the video footage. In particular, we included both professionally produced clips (e.g., advertisements, TV interviews) and everyday videos (e.g., bodycam or cell phone footage). We took this approach because we expected that the quality of video footage might influence its 
persuasive power. In particular, amateur videos might be seen as more "realistic" or less manufactured than professional footage. Second, we considered the novelty of the claims made in the video. In line with a "seeing is believing" mentality, we hypothesized greater differences between video and text in cases where the events and scenarios depicted seemed more improbable or surprising on their face. Finally, we considered the level of editing of the footage. In particular, we selected clips that varied in the degree to which they employed camera cuts, under the assumption that heavily edited clips might seem more suspect than clips showing events occurring in real-time.

The final stimulus set consisted of six clips - three of which were political in nature and three of which were non-political (see here). These clips were specifically selected to probe our central hypotheses. Importantly, though, we do not consider these clips to be a representative sample of the universe of potential content.

1. Obama Deepfake: a deepfake video of Barack Obama created by Buzzfeed and voiced by comedian Jordan Peele, where Obama appears to call Donald Trump a "total and complete dipshit."

2. Trump Shutdown: a news video from CNN where Trump takes responsibility for the December 2018-January 2019 federal government shutdown during a meeting with Chuck Schumer and Nancy Pelosi.

3. Police Brutality: a local news segment containing police bodycam footage from a March 2016 traffic stop.

4. Alternative Health Tips: an excerpt of an interview with actress Gwyneth Paltrow on The Dr. Oz Show where she discusses her favorite alternative health remedies.

5. Out Stain Remover: an infomercial for a stain remover that includes a real-time product demonstration.

6. Puracy Stain Remover: an advertisement for a stain remover using a customer narrative and employing a large number of camera cuts, with the product demonstration occurring off-screen.

\section{Outcome Measures}

Table S17 describes the outcome measures for our pilot study. The exact wording of these measures is available here. We included two measures of persuasion for the Obama deepfake. The first assessed approval of Obama, where higher ratings indicate greater disapproval of Obama. Note, however, that our pooled results remain substantively similar if we reverse-code this measure or exclude the Obama deepfake from the persuasion analyses. The second assessed beliefs about the level of partisan conflict in the United States, where higher ratings indicate perceptions of stronger conflict. Throughout this document, we present these two outcomes separately. 


\begin{tabular}{|c|c|c|}
\hline Outcome & Label & Description of Variable \\
\hline $\begin{array}{c}\text { Believability of } \\
\text { Content }\end{array}$ & Belief & $\begin{array}{l}\text { Respondents' belief that an event shown in the clip or described } \\
\text { in the transcript actually occurred. Measured on a five-point } \\
\text { scale, where } 1=\text { "Definitely did not happen" and } 5=\text { "Definitely } \\
\text { happened." }\end{array}$ \\
\hline
\end{tabular}

Persuasion Persuasion

How persuaded respondents were by the story, based on either a behavioral measure of their likelihood of purchasing a product (Alternative Health Tips, Out, Puracy) or an attitudinal measure (Obama Deepfake, Trump Shutdown, Police Brutality). Measured on a five-point scale, where 1 is the least and 5 is the most persuaded.

Perceptions of Polarization Respondents' beliefs about the level of conflict between Democrats and Republicans. Measured on a four-point scale, where $1=$ "No conflict" and $4=$ "Very strong conflict." Asked only after the Obama deepfake.

\begin{tabular}{|c|c|c|}
\hline $\begin{array}{c}\text { Personal } \\
\text { Engagement Index }\end{array}$ & Engagement & $\begin{array}{l}\text { Respondents' personal engagement with the stimulus, calcu- } \\
\text { lated as a simple mean of the Interest and Learn More outcomes } \\
\text { described below. }\end{array}$ \\
\hline Personal Interest & Interest & $\begin{array}{l}\text { How interesting respondents found the message. Measured on } \\
\text { a five-point scale, where } 1=\text { "Not at all interesting" and } 5=\text { "Ex- } \\
\text { tremely interesting." }\end{array}$ \\
\hline $\begin{array}{c}\text { Interest in Learning } \\
\text { More }\end{array}$ & Learn More & $\begin{array}{l}\text { How interested respondents were in learning more about the } \\
\text { subject of the message. Measured on a five-point scale, where } \\
1=\text { "Not at all interested" and } 5=\text { "Extremely interested." }\end{array}$ \\
\hline Factual Recall & Recall & $\begin{array}{l}\text { Factual recall of story details, measured using } 1-2 \text { items (one for } \\
\text { the Obama Deepfake, two for all other messages). Respondents } \\
\text { received a score of } 0 \text { for answering zero questions correctly, } 0.5 \\
\text { for answering one of two questions correctly, and } 1 \text { if they an- } \\
\text { swered all questions correctly. }\end{array}$ \\
\hline
\end{tabular}

Table S17: Description of outcome variables included in the Spring 2019 pilot study. 


\subsection{Pooled Analyses}

Figure S44 plots the overall treatment effect of assignment to video versus text, pooling across our six video clips ( $n=20,428$ ). This pooled dataset includes six sets of outcomes each for 598 respondents (from the first two waves of data collection) and four sets of outcomes each for 4210 respondents (from the third wave of data collection). We present results from pooled OLS models, as well as models that include fixed effects for both respondents and messages. In both cases, standard errors are clustered by respondent. Overall, we find that assignment to the video condition has a discernible, positive effect on all six outcomes, relative to the text condition. However, the magnitude of this effect, in all cases, is quite small (Cohen's $d \leq 0.12$ for all items, see Figure S46).

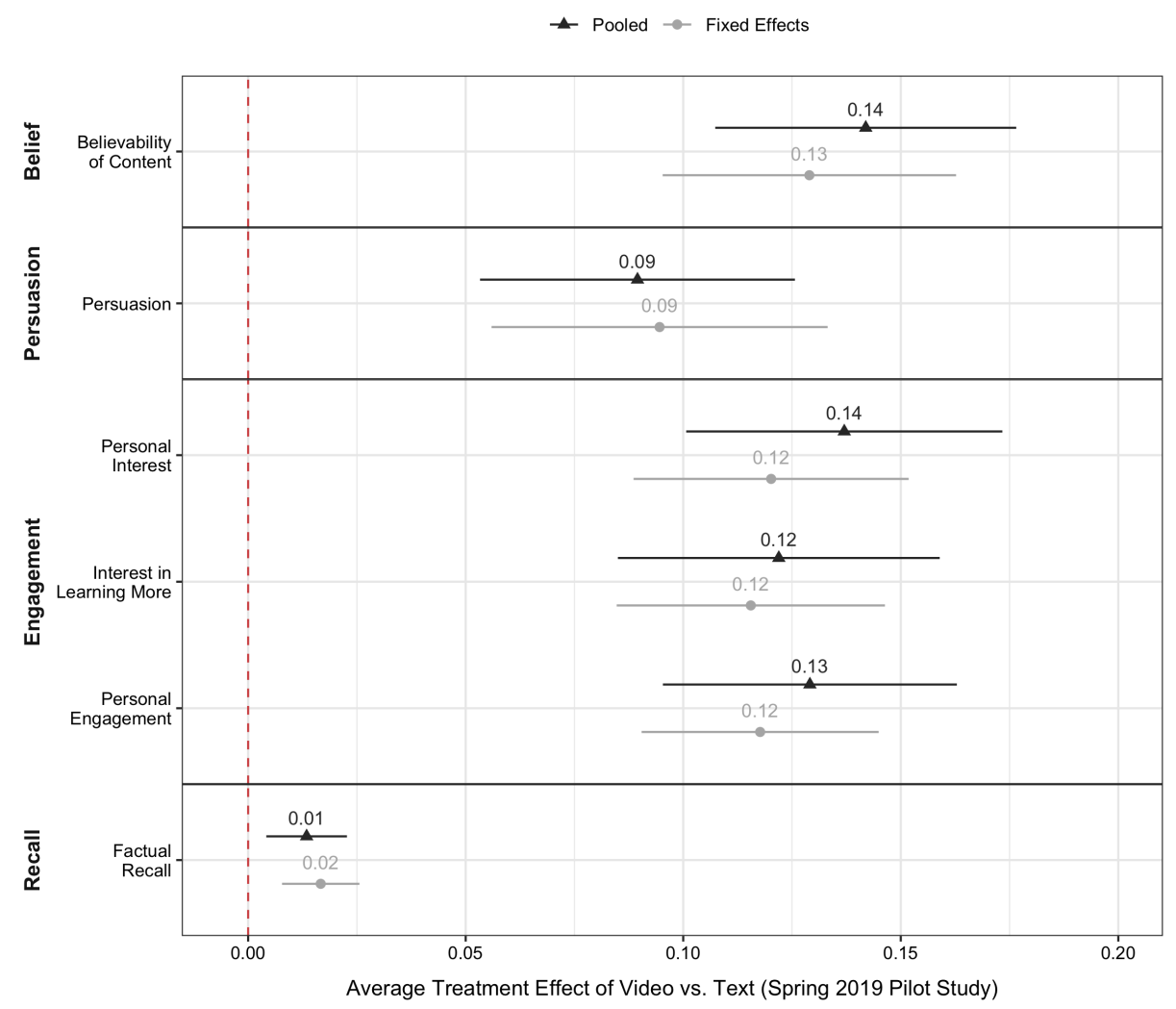

Figure S44: Average treatment effect (ATE) of assignment to the video versus text condition on ratings of believability, persuasion, personal engagement, and factual recall for the Spring 2019 pilot study. Belief, persuasion, and personal engagement are all measured using five-point scales, whereas factual recall scores range from 0 to 1 . Estimated effects and 95\% confidence intervals come from pooled OLS models with standard errors clustered by respondent. 


\section{Comparison of Political and Non-Political Stimuli}

We then divide our six stimuli into those that are political in nature and those that are not. The political stimuli include the Obama deepfake, the Trump government shutdown clip, and the police brutality clip. The non-political stimuli are the two advertisements for the Out and Puracy stain removers, as well as the Gwyneth Paltrow interview about alternative health tips. Figure S45 summarizes the differences in means between the video and text conditions for political versus non-political stimuli, and Table S18 reports the regression results from models interacting an indicator of treatment status (video versus text) and an indicator of stimulus type (political versus non-political).

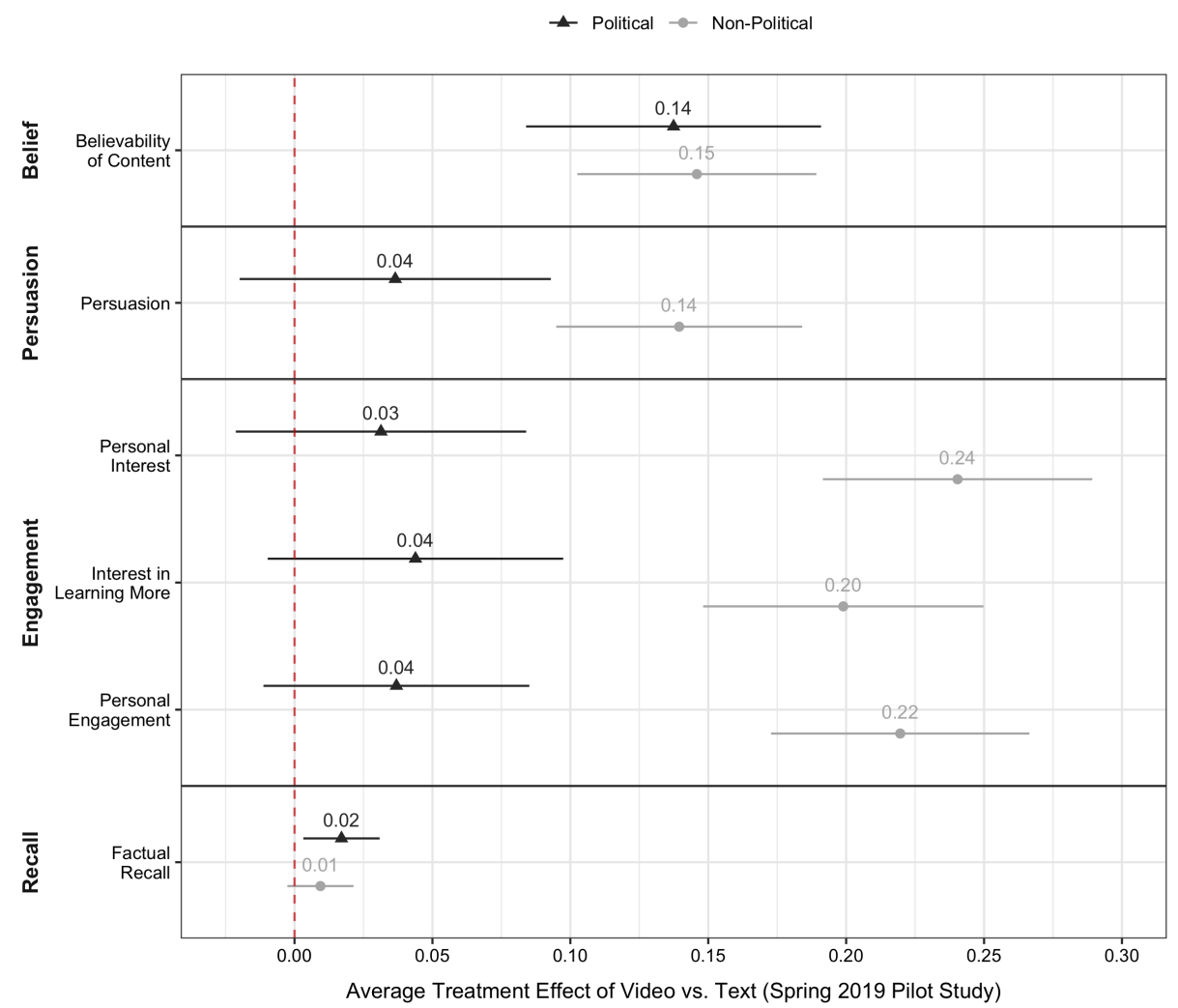

Figure S45: Average treatment effect (ATE) of assignment to the video versus text condition on ratings of believability, persuasion, personal engagement, and factual recall for the Spring 2019 pilot study, disaggregated by message type (political vs. non-political). Belief, persuasion, and personal engagement are all measured using five-point scales, whereas factual recall scores range from 0 to 1 . Estimated effects and $95 \%$ confidence intervals come from pooled OLS models with standard errors clustered by respondent. 


\begin{tabular}{lcccccc}
\hline & Belief & Persuasion & Interest & Learn More & Engagement & Recall \\
\hline Video & $0.15^{* * *}$ & $0.14^{* * *}$ & $0.24^{* * *}$ & $0.20^{* * *}$ & $0.22^{* * *}$ & 0.01 \\
& $(0.02)$ & $(0.02)$ & $(0.02)$ & $(0.03)$ & $(0.02)$ & $(0.01)$ \\
Political & $0.12^{* * *}$ & $0.52^{* * *}$ & $0.28^{* * *}$ & $0.11^{* * *}$ & $0.20^{* * *}$ & $0.10^{* * *}$ \\
& $(0.02)$ & $(0.03)$ & $(0.03)$ & $(0.03)$ & $(0.02)$ & $(0.01)$ \\
Video $\times$ Political & -0.01 & $-0.10^{* * *}$ & $-0.21^{* * *}$ & $-0.16^{* * *}$ & $-0.18^{* * *}$ & 0.01 \\
& $(0.03)$ & $(0.04)$ & $(0.04)$ & $(0.04)$ & $(0.03)$ & $(0.01)$ \\
Constant & $3.52^{* * *}$ & $2.88^{* * *}$ & $2.81^{* * *}$ & $2.91^{* * *}$ & $2.86^{* * *}$ & $0.65^{* * *}$ \\
& $(0.01)$ & $(0.02)$ & $(0.02)$ & $(0.02)$ & $(0.02)$ & $(0.005)$ \\
\hline $\mathrm{N}$ & 20,419 & 20,421 & 20,420 & 20,417 & 20,425 & 20,428 \\
R-squared & 0.01 & 0.03 & 0.01 & 0.003 & 0.01 & 0.02 \\
\hline
\end{tabular}

${ }^{* * *} \mathrm{p}<.01 ;{ }^{* *} \mathrm{p}<.05 ;{ }^{*} \mathrm{p}<.1$

Table S18: Average treatment effect of video versus text for political (Obama deepfake, Trump shutdown, police brutality) versus non-political (alternative health tips, Out stain remover, Puracy stain remover) stimuli. All outcomes are measured using five-point scales, except for recall, which ranges from 0 to 1 based on the number of correct responses to a series of factual questions. Standard errors are clustered by respondent. 


\section{Standardized Results}

The following section reports results from models with standardized dependent variables. Figure S46 plots the estimated treatment effect of assignment to the video versus text condition across all six stories, and Figure S47 plots the estimated treatment effects for political versus non-political stimuli. All estimated effects can be interpreted in terms of standard deviations of the outcome scale.

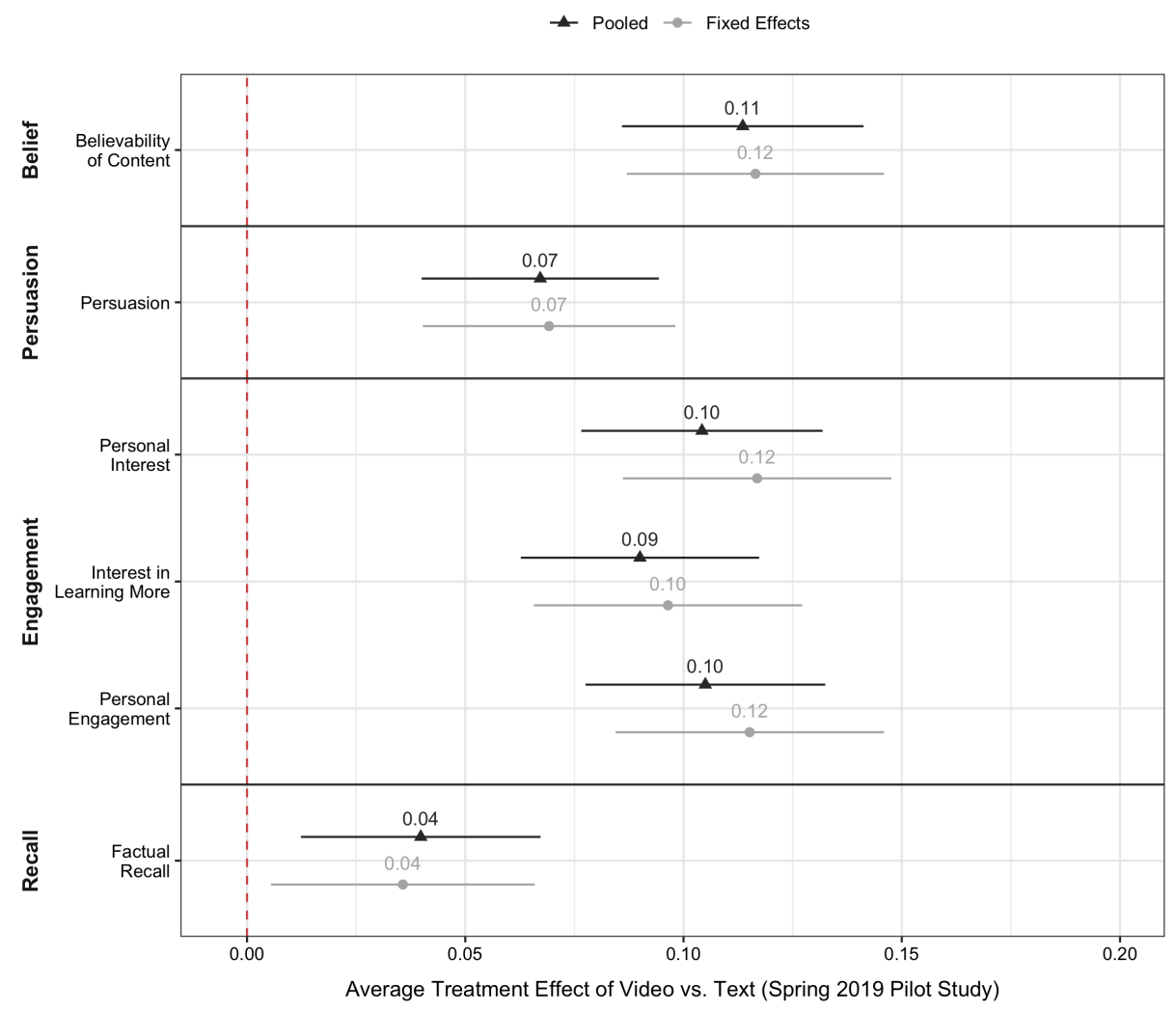

Figure S46: Average treatment effect (ATE) of assignment to the video versus text condition on ratings of believability, persuasion, personal engagement, and factual recall for the Spring 2019 pilot study. All estimates are expressed in terms of standard deviations. Belief, persuasion, and personal engagement are all measured using five-point scales, whereas factual recall scores range from 0 to 1 . Estimated effects and 95\% confidence intervals come from pooled OLS models with standard errors clustered by respondent. 


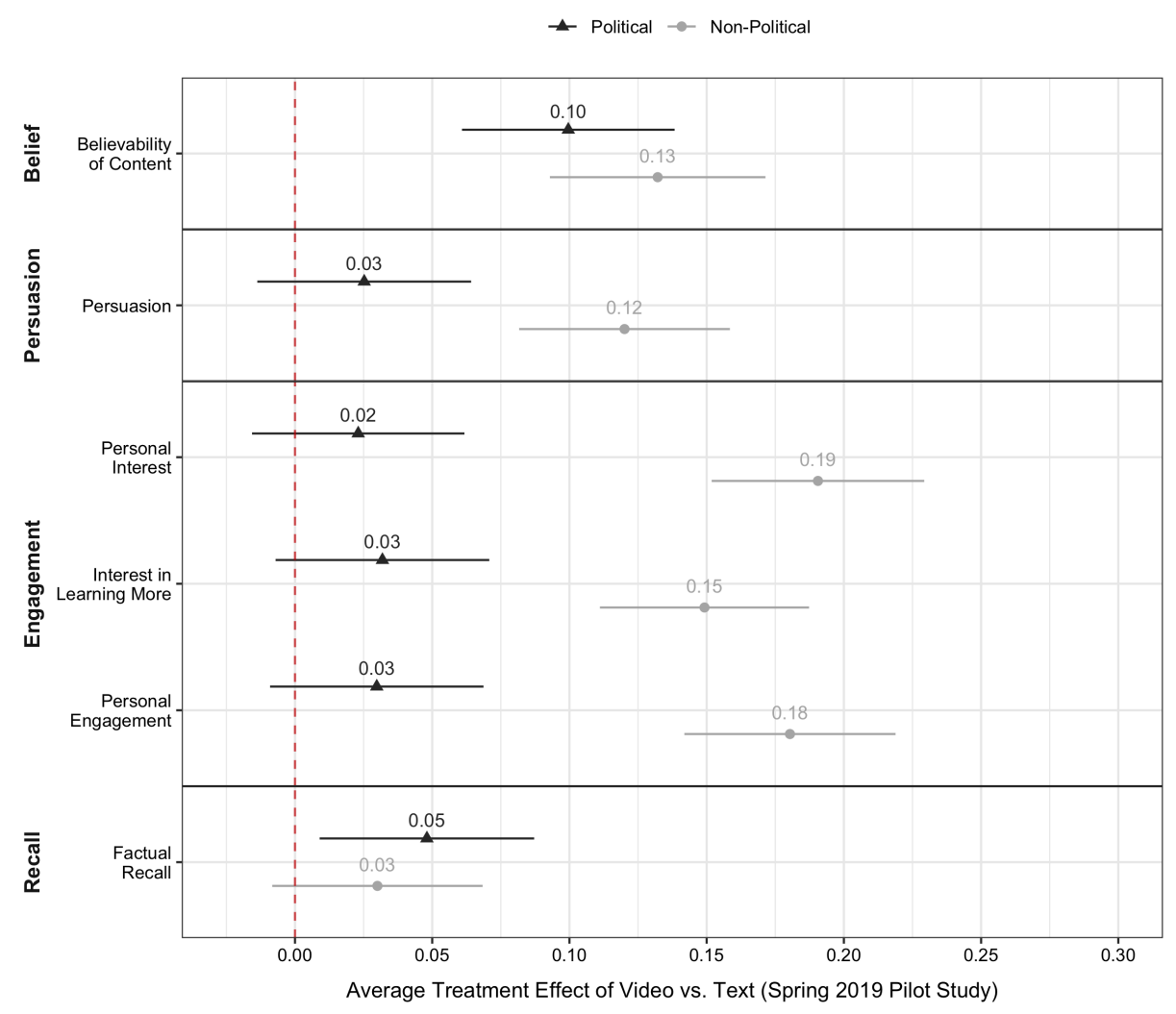

Figure S47: Average treatment effect (ATE) of assignment to the video versus text condition on ratings of believability, persuasion, personal engagement, and factual recall for the Spring 2019 pilot study, disaggregated by message type (political vs. non-political). All estimates are expressed in terms of standard deviations. Belief, persuasion, and personal engagement are all measured using five-point scales, whereas factual recall scores range from 0 to 1 . Estimated effects and $95 \%$ confidence intervals come from pooled OLS models with standard errors clustered by respondent. 


\subsection{Message-Specific Analyses}

Figure S48 plots the average treatment effects of assignment to the video vs. text condition in our Spring 2019 pilot study, disaggregated by persuasive message. Believability, persuasion, and the personal engagement items were all measured using five-point scales, and perceptions of partisan conflict were measured using a four-point scale. Measures of factual recall range from 0 to 1 , based on the number of correct responses to a series of factual questions. For each stimulus, we estimate the difference in means between the video and text conditions using OLS with robust standard errors. Full regression tables can be found in Tables S19 to S25, and estimates using standardized dependent variables can be found in Figure S49.
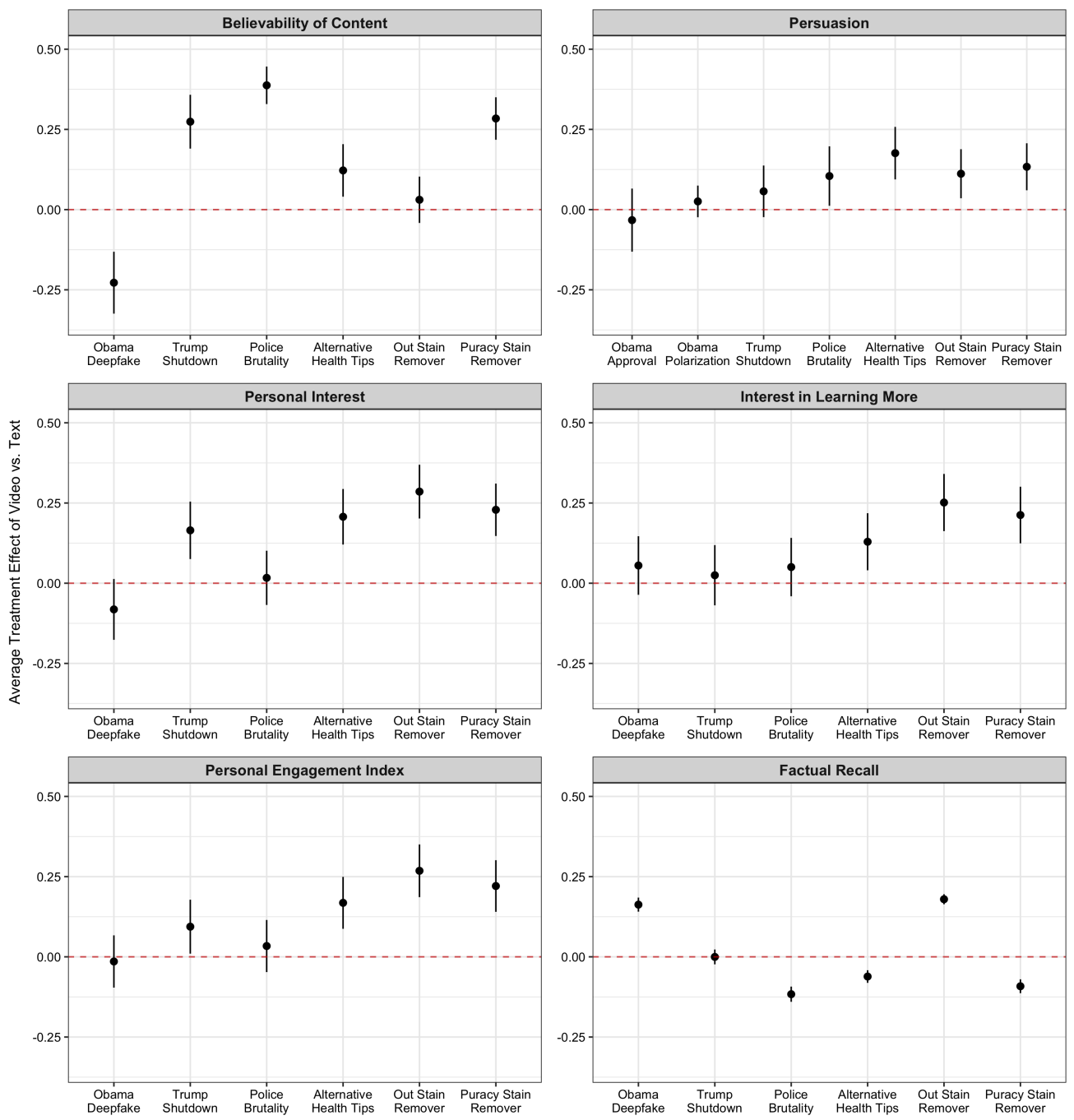

Figure S48: Average treatment effect of assignment to the video versus text condition in the 2019 pilot study, disaggregated by persuasive message. Estimated effects and $95 \%$ confidence intervals come from OLS models with robust standard errors (HC2 variant). 


\section{Regression Results}

\begin{tabular}{lcccccc}
\hline & $\begin{array}{c}\text { Belief: } \\
\text { Obama }\end{array}$ & $\begin{array}{c}\text { Belief: } \\
\text { Trump }\end{array}$ & $\begin{array}{c}\text { Belief: } \\
\text { Police }\end{array}$ & $\begin{array}{c}\text { Belief: } \\
\text { Alt. Health }\end{array}$ & $\begin{array}{c}\text { Belief: } \\
\text { Out }\end{array}$ & $\begin{array}{c}\text { Belief: } \\
\text { Puracy }\end{array}$ \\
\hline Video & $-0.23^{* * *}$ & $0.27^{* * *}$ & $0.39^{* * *}$ & $0.12^{* * *}$ & 0.03 & $0.28^{* * *}$ \\
& $(0.05)$ & $(0.04)$ & $(0.03)$ & $(0.04)$ & $(0.04)$ & $(0.03)$ \\
Constant & $2.92^{* * *}$ & $3.87^{* * *}$ & $4.11^{* * *}$ & $3.56^{* * *}$ & $3.55^{* * *}$ & $3.45^{* * *}$ \\
& $(0.03)$ & $(0.03)$ & $(0.02)$ & $(0.03)$ & $(0.02)$ & $(0.02)$ \\
\hline $\mathrm{N}$ & 3419 & 3365 & 3359 & 3419 & 3424 & 3433 \\
R-squared & 0.01 & 0.01 & 0.05 & 0.002 & 0.0002 & 0.02 \\
\hline \multirow{2}{*}{$* * * \mathrm{p}<.01 ;{ }^{* *} \mathrm{p}<.05 ;{ }^{*} \mathrm{p}<.1$} & & & &
\end{tabular}

Table S19: Effect of video versus text on respondents' belief that a depicted event or claim actually occurred. $p$ values are based on robust standard errors (HC2 variant). The scale ranged from 1 to 5 , where $1=$ "definitely did not happen" and $5=$ "definitely happened." Positive coefficients indicate that the story was, on average, more believable to respondents in the video versus text condition.

\begin{tabular}{lcccc}
\hline & $\begin{array}{c}\text { Approval: } \\
\text { Obama }\end{array}$ & $\begin{array}{c}\text { Polarization: } \\
\text { Obama }\end{array}$ & $\begin{array}{c}\text { Persuasion: } \\
\text { Trump }\end{array}$ & $\begin{array}{c}\text { Persuasion: } \\
\text { Police }\end{array}$ \\
\hline Video & -0.03 & 0.03 & 0.06 & $0.10^{* *}$ \\
& $(0.05)$ & $(0.03)$ & $(0.04)$ & $(0.05)$ \\
Constant & $2.73^{* * *}$ & $3.35^{* * *}$ & $3.95^{* * *}$ & $3.51^{* * *}$ \\
& $(0.04)$ & $(0.02)$ & $(0.03)$ & $(0.03)$ \\
\hline $\mathrm{N}$ & 3420 & 3418 & 3367 & 3360 \\
R-squared & 0.0001 & 0.0003 & 0.001 & 0.001 \\
\hline
\end{tabular}

${ }^{* * *} \mathrm{p}<.01 ;{ }^{* *} \mathrm{p}<.05 ;{ }^{*} \mathrm{p}<.1$

Table S20: Effect of video versus text for attitudinal measures of persuasion. $p$ values are based on robust standard errors (HC2 variant). For the Obama deepfake, persuasion was measured in terms of approval of Obama's performance, where higher ratings indicate greater disapproval of his performance, and views on polarization, where higher ratings indicate perceptions of stronger partisan conflict. For the Trump shutdown clip, persuasion was measured in terms of belief that Trump was responsible for the 2018-19 government shutdown. For the police brutality clip, persuasion was measured in terms of belief that the police behaved inappropriately. For all measures except for polarization, the scale ranged from 1 to 5 . For polarization, the scale ranged from 1 to 4 , where $1=$ "no conflict" and $4=$ "very strong conflict." Positive coefficients indicate that video was more persuasive than text in shaping respondents' attitudes. 


\begin{tabular}{lccc}
\hline & $\begin{array}{c}\text { Persuasion: } \\
\text { Alt. Health }\end{array}$ & $\begin{array}{c}\text { Persuasion: } \\
\text { Out }\end{array}$ & $\begin{array}{c}\text { Persuasion: } \\
\text { Puracy }\end{array}$ \\
\hline Video & $0.18^{* * *}$ & $0.11^{* * *}$ & $0.13^{* * *}$ \\
& $(0.04)$ & $(0.04)$ & $(0.04)$ \\
Constant & $2.69^{* * *}$ & $3.01^{* * *}$ & $2.94^{* * *}$ \\
& $(0.03)$ & $(0.03)$ & $(0.03)$ \\
\hline N & 3419 & 3423 & 3432 \\
R-squared & 0.01 & 0.002 & 0.004 \\
\hline
\end{tabular}

${ }^{* * *} \mathrm{p}<.01 ;{ }^{* *} \mathrm{p}<.05 ;{ }^{*} \mathrm{p}<.1$

Table S21: Effect of video versus text for behavioral measures of persuasion. $p$ values are based on robust standard errors (HC2 variant). For all items, the scale ranges from 1 to 5 , where higher scores indicate a greater likelihood to use or purchase the featured product. Positive coefficients indicate that video was more persuasive than text in shaping respondents' intended consumption behavior.

\begin{tabular}{lcccccc}
\hline & $\begin{array}{c}\text { Interest: } \\
\text { Obama }\end{array}$ & $\begin{array}{c}\text { Interest: } \\
\text { Trump }\end{array}$ & $\begin{array}{c}\text { Interest: } \\
\text { Police }\end{array}$ & $\begin{array}{c}\text { Interest: } \\
\text { Alt. Health }\end{array}$ & $\begin{array}{c}\text { Interest: } \\
\text { Out }\end{array}$ & $\begin{array}{c}\text { Interest: } \\
\text { Puracy }\end{array}$ \\
\hline Video & $-0.08^{*}$ & $0.16^{* * *}$ & 0.02 & $0.21^{* * *}$ & $0.29^{* * *}$ & $0.23^{* * *}$ \\
& $(0.05)$ & $(0.05)$ & $(0.04)$ & $(0.04)$ & $(0.04)$ & $(0.04)$ \\
Constant & $2.79^{* * *}$ & $3.09^{* * *}$ & $3.40^{* * *}$ & $2.77^{* * *}$ & $2.88^{* * *}$ & $2.78^{* * *}$ \\
& $(0.03)$ & $(0.03)$ & $(0.03)$ & $(0.03)$ & $(0.03)$ & $(0.03)$ \\
\hline $\mathrm{N}$ & 3418 & 3367 & 3360 & 3418 & 3424 & 3433 \\
R-squared & 0.001 & 0.004 & 0.0000 & 0.01 & 0.01 & 0.01 \\
\hline
\end{tabular}

${ }^{* * *} \mathrm{p}<.01{ }^{* *} \mathrm{p}<.05 ;{ }^{*} \mathrm{p}<.1$

Table S22: Effect of video versus text on respondents' interest in the story. $p$ values are based on robust standard errors (HC2 variant). The scale ranged from 1 to 5 , where $1=$ "not at all interesting" and $5=$ "extremely interesting." Positive coefficients indicate that video was more interesting than text.

\begin{tabular}{lcccccc}
\hline & $\begin{array}{c}\text { Learn More: } \\
\text { Obama }\end{array}$ & $\begin{array}{c}\text { Learn More: } \\
\text { Trump }\end{array}$ & $\begin{array}{c}\text { Learn More: } \\
\text { Police }\end{array}$ & $\begin{array}{c}\text { Learn More: } \\
\text { Alt. Health }\end{array}$ & $\begin{array}{c}\text { Learn More: } \\
\text { Out }\end{array}$ & $\begin{array}{c}\text { Learn More: } \\
\text { Puracy }\end{array}$ \\
\hline Video & 0.06 & 0.02 & 0.05 & $0.13^{* * *}$ & $0.25^{* * *}$ & $0.21^{* * *}$ \\
& $(0.05)$ & $(0.05)$ & $(0.05)$ & $(0.05)$ & $(0.05)$ & $(0.04)$ \\
Constant & $2.86^{* * *}$ & $2.94^{* * *}$ & $3.27^{* * *}$ & $3.11^{* * *}$ & $2.83^{* * *}$ & $2.79^{* * *}$ \\
& $(0.03)$ & $(0.03)$ & $(0.03)$ & $(0.03)$ & $(0.03)$ & $(0.03)$ \\
\hline $\mathrm{N}$ & 3418 & 3367 & 3361 & 3416 & 3422 & 3433 \\
R-squared & 0.0004 & 0.0001 & 0.0004 & 0.002 & 0.01 & 0.01 \\
\hline
\end{tabular}

${ }^{* * *} \mathrm{p}<.01 ;{ }^{* *} \mathrm{p}<.05 ;{ }^{*} \mathrm{p}<.1$

Table S23: Effect of video versus text on respondents' interest in learning more about the subject of the story. $p$ values are based on robust standard errors (HC2 variant). The scale ranged from 1 to 5 , where 1 $=$ "not at all interested" and $5=$ "extremely interested." Positive coefficients indicate that video was more engaging than text. 


\begin{tabular}{lcccccc}
\hline & $\begin{array}{c}\text { Engage: } \\
\text { Obama }\end{array}$ & $\begin{array}{c}\text { Engage: } \\
\text { Trump }\end{array}$ & $\begin{array}{c}\text { Engage: } \\
\text { Police }\end{array}$ & $\begin{array}{c}\text { Engage: } \\
\text { Alt. Health }\end{array}$ & $\begin{array}{c}\text { Engage: } \\
\text { Out }\end{array}$ & $\begin{array}{c}\text { Engage: } \\
\text { Puracy }\end{array}$ \\
\hline Video & -0.01 & $0.09^{* *}$ & 0.03 & $0.17^{* * *}$ & $0.27^{* * *}$ & $0.22^{* * *}$ \\
& $(0.04)$ & $(0.04)$ & $(0.04)$ & $(0.04)$ & $(0.04)$ & $(0.04)$ \\
Constant & $2.83^{* * *}$ & $3.02^{* * *}$ & $3.34^{* * *}$ & $2.94^{* * *}$ & $2.85^{* * *}$ & $2.79^{* * *}$ \\
& $(0.03)$ & $(0.03)$ & $(0.03)$ & $(0.03)$ & $(0.03)$ & $(0.03)$ \\
\hline $\mathrm{N}$ & 3420 & 3368 & 3361 & 3419 & 3424 & 3433 \\
R-squared & 0.0000 & 0.001 & 0.0002 & 0.005 & 0.01 & 0.01 \\
\hline
\end{tabular}

${ }^{* * *} \mathrm{p}<.01 ;{ }^{* *} \mathrm{p}<.05 ;{ }^{*} \mathrm{p}<.1$

Table S24: Effect of video versus text on ratings of personal engagement (based on the mean of responses to the personal interest and interest in learning more variables). $p$ values are based on robust standard errors (HC2 variant). The scale ranged from 1 to 5 , where lower ratings indicate less engagement. Positive coefficients indicate that video was more engaging than text.

\begin{tabular}{lcccccc}
\hline & $\begin{array}{c}\text { Recall: } \\
\text { Obama }\end{array}$ & $\begin{array}{c}\text { Recall: } \\
\text { Trump }\end{array}$ & $\begin{array}{c}\text { Recall: } \\
\text { Police }\end{array}$ & $\begin{array}{c}\text { Recall: } \\
\text { Alt. Health }\end{array}$ & $\begin{array}{c}\text { Recall: } \\
\text { Out }\end{array}$ & $\begin{array}{c}\text { Recall: } \\
\text { Puracy }\end{array}$ \\
\hline Video & $0.16^{* * *}$ & -0.0003 & $-0.12^{* * *}$ & $-0.06^{* * *}$ & $0.18^{* * *}$ & $-0.09^{* * *}$ \\
& $(0.01)$ & $(0.01)$ & $(0.01)$ & $(0.01)$ & $(0.01)$ & $(0.01)$ \\
Constant & $0.79^{* * *}$ & $0.68^{* * *}$ & $0.77^{* * *}$ & $0.83^{* * *}$ & $0.43^{* * *}$ & $0.69^{* * *}$ \\
& $(0.01)$ & $(0.01)$ & $(0.01)$ & $(0.01)$ & $(0.005)$ & $(0.01)$ \\
\hline $\mathrm{N}$ & 3420 & 3369 & 3362 & 3420 & 3424 & 3433 \\
R-squared & 0.06 & 0.0000 & 0.03 & 0.01 & 0.13 & 0.02 \\
\hline$* * *$
\end{tabular}

Table S25: Effect of video versus text on respondents' factual recall of story details. $p$ values are based on robust standard errors (HC2 variant). Scores range from 0 to 1; respondents received a score of 0 when they got zero recall questions right, 0.5 when they got one recall question right, and 1 when they got two factual recall questions right. Given the short length of the Obama deepfake, we only included a single recall item for this story, so the resulting score is a binary indicating whether respondents got that question correct. Positive coefficients indicate that recall was higher, on average, in the video versus text condition. 


\section{Standardized Results}
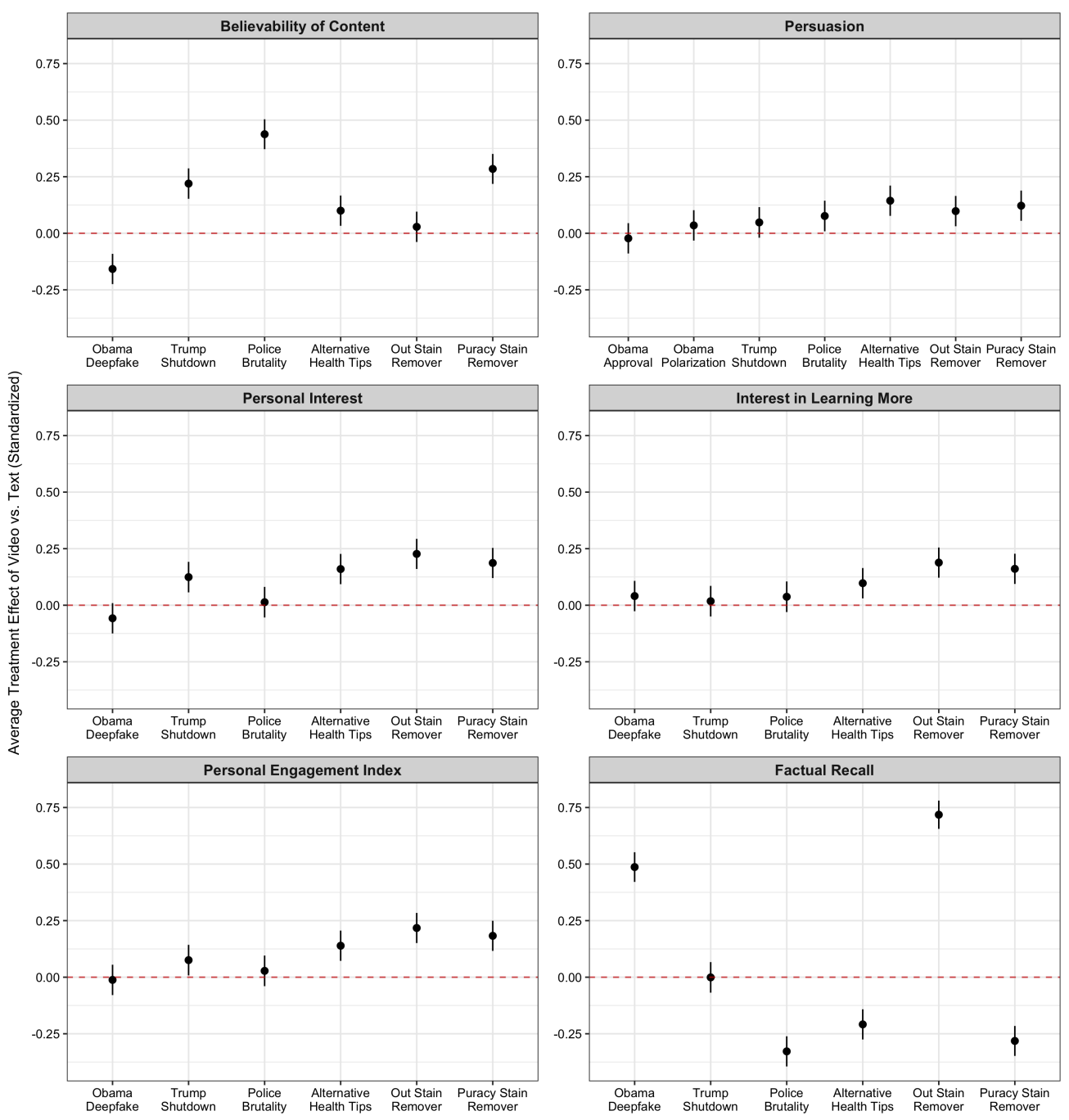

Figure S49: Average treatment effect of assignment to the video versus text condition in the Spring 2019 pilot study, disaggregated by persuasive message. Estimated effects and $95 \%$ confidence intervals come from OLS models with robust standard errors (HC2 variant). All estimates are expressed in terms of standard deviations. 


\section{References}

[1] HOY Li, A Bailey, D Huynh, J Chan, YouTube as a source of information on COVID-19: a pandemic of misinformation? BMJ Global Health 5, e002604 (2020).

[2] MX Delli Carpini, S Keeter, What Americans Know about Politics and Why It Matters. (Yale University Press, New Haven, CT), (1996).

[3] S Frederick, Cognitive Reflection and Decision Making. Journal of Economic Perspectives 19, 25-42 (2005).

[4] G Pennycook, DG Rand, Lazy, not biased: Susceptibility to partisan fake news is better explained by lack of reasoning than by motivated reasoning. Cognition 188, 39-50 (2019).

[5] KS Thomson, DM Oppenheimer, Investigating an alternate form of the cognitive reflection test. Judgment and Decision Making 11, 99-113 (2016).

[6] AM Guess, K Munger, Digital Literacy and Online Political Behavior, (Open Science Framework), Preprint (2020).

[7] AJ Berinsky, MF Margolis, MW Sances, Separating the Shirkers from the Workers? Making Sure Respondents Pay Attention on Self-Administered Surveys. American Journal of Political Science 58, 739-753 (2014).

[8] J Hainmueller, J Mummolo, Y Xu, How Much Should We Trust Estimates from Multiplicative Interaction Models? Simple Tools to Improve Empirical Practice. Political Analysis 27, 163-192 (2019).

[9] A Coppock, OA McClellan, Validating the demographic, political, psychological, and experimental results obtained from a new source of online survey respondents. Research \& Politics 6, 1-14 (2019). 